\title{
Quarterly Briefing Book on \\ Environmental and Waste Management Activities
}

Prepared for the U.S. Department of Energy Office of Environmental Restoration and Waste Management

\section{(28) Westinghouse \\ Hanford Company Richland, Washington}

Hanford Operations and Engineering Contractor for the

U.S. Department of Energy under Contract DE-AC06-87RL10930 
WHC-SP- $-0434-11$

DE92 001721

\section{Quarterly Briefing Book on Environmental and Waste Management Activiti $\div 5$}

M. C. Brown

Date Published

June 1991

Prepared for the U.S. Department of Energy Office of Environmental Restoration and Waste Management

\footnotetext{
Westinghouse
Hanford Company

Hanford Operations and Engineering Contractor for the

U.S. Department of Energy under Contract DE-AC06-87RL10930
}

Approved for Public Release 


\section{LEGAL DISCLAIMER}

This report was prepared as an account of work sponsored by an agency of the United States Government. Neither the

United States Government nor any agency thereof, nor any of their employees, nor any of their contractors, subcontractors or their employees, makes any warranty, express or implied, or assumes any legal liability or responsibility for the accuracy, completeness, or any third party's use or the results of such use of any information, apparatus, product, or process disclosed, or represents that its use would not infringe privately owned rights. Reference herein to any specific commercial product, process, or service by trade name, trademark, manufacturer, or utherwise, does not necessarily constitute or imply its endorsement, recommendation, or favoring by the United States Government or any agency thereof or its contractors or subcontractors. The views and opinions of authors expressed herein do not necessarily state or reflect those of the United States Government or any agency thereof.

This report has been reproduced from the best available copy.

Printed in the United States of America

DISCLM-2.CHP (1.91) 


\section{QUARTERLY BRIEFING BOOK ON ENVIRONMENTAL AND WASTE MANAGEMENT ACTIVITIES}

\section{PREFACE}

The purpose of the Quarterly Briefing Book on Environmental and Waste Management Activities is to provide managers and senior staff at the U.S. Department of Energy-Richland Operations Office and its contractors with timely and concise information on Hanford Site environmental and waste management activities. Each edition updates the information on the topics in the previous edition, deletes those determined not to be of current interest, and adds new topics to keep up to date with changing environmental and waste management requirements and issues.

Section $A$ covers current waste management and environmental restoration issues. In Section $B$ are writeups on national or site-wide environmental and waste management topics. Section $C$ has writeups on program- and wastespecific environmental and waste management topics. Section D provides information on waste sites and inventories on the site.

This edition includes an alphabetized listing of the writeups. It is hoped this listing will make it easier for readers to find the information they seek. A change bar at the top of a section indicates the whole section is new.

This edition was compiled and edited by M. C. Brown. 
This page intentionally left blank. 


\section{CONTENTS}

SECTION A: CURRENT ISSUES AND ACTIONS

A. 1 - TRI-PARTY AGREEMENT . . . . . . . . . . . . . . . . . A-1

A.2 - 30-YEAR CLEANUP GOAL . . . . . . . . . . . . . . . . A-4

A.3 - LIQUID WASTES DISCHARGED TO THE GROUND . . . . . . . . . . . . A-5

A.4 - WASTE TANK SAFETY . . . . . . . . . . . . . . . . . A-7

A.4.1 WATCH LIST TANKS .................. . A-7

A.4.2 TANK LEAK VOLUME . . . . . . . . . . . . . . . . A-8

A.4.3 NEW TANKS . . . . . . . . . . . . . . . . . A-8

A.4.4 TANK SY-101 STATUS ................. A-9

A.5 - RISK ASSESSMENT FOR HANFORD WASTE VITRIFICATION
SYSTEMS . . . . . . . . . . . . . . . . . . . A-10

A.6 - B PlANT AlteRnAtive StUdies . . . . . . . . . . . . . . A-11

A.7 - EXPEDITED RESPONSE ACTIONS . . . . . . . . . . . . A- A 13

A.7.1 EXPEDITED RESPONSE ACTION PROGRAM . . . . . . . . . . . . A-13

A.7.2 618-9 BURIAL GROUND ................ . . A-13

A.7.3 316-5 PROCESS TRENCHES ............... . A-14

A.7.4 200 WEST AREA CARBON TETRACHLORIDE . . . . . . . . . A-15

A.8 - NEW PRODUCTION REACTOR . . . . . . . . . . . . . . . A-16

A.9 - UO3 STABILIZATION CAMPAIGN . . . . . . . . . . . . . . A-17

A.10 - PLUTONIUM FINISHING PLANT RESTART . . . . . . . . . . . . . A-18

A.11 - GENERAL ACCOUNTING OFFICE REVIEW OF U.S. DEPARTMENT
OF ENERGY'S WASTE MANAGEMENT/CLEANUP PROGRAM . . . . . . . . A A-20

A.12 - FEDERAL FACILITY COMPLIANCE ACT (S. 596) . . . . . . . . . A-21

A.13 - LIQUID EFFLUENT STUDY . . . . . . . . . . . . . . . . A-22

A.14 - CONTAMINATION CONTROL IMPROVEMENT PROJECT . . . . . . . . . . . A-23

A.15 - WEAPONS COMPLEX RECONFIGURATION - HANFORD SITE
PROPOSAL . . . . . . . . . . . . . . . . A-25

A.16 - RESOURCE CONSERVATION AND RECOVERY ACT REAUTHORIZATION . . . . A-26

A.17 - EMPLOYEES CONCERNS PROGRAM . . . . . . . . . . . . . . A-28

A.18 - HANFORD INTEGRATED PLANNING PROCESS . . . . . . . . . . . . A-30 
CONTENTS (cont)

A.19 - HORN RAPIDS CONTAMINATION ............. A-32

A.20 - GENERAL ACCOUNTING OFFICE INVESTIGATION OF SOIL AND GROUNDWATER MONITORING . . . . . . . . . . . . A-33

SECTION B: NATIONAL OR SITE-WIDE ENVIRONMENTAL AND WASTE MANAGEMENT ACTIVITIES

B.1 FY 1993 ENVIRONMENTAL MANAGEMENT FIELD BUDGET REQUEST . . . . . . B-1

B.2 - FIVE-YEAR PLAN .................... B-3

B.2.1 THE DOE-HQ FIVE-YEAR PLAN . . . . . . . . . . . . . B-3

B.2.2 HANFORD SITE-SPECIFIC PLAN . . . . . . . . . . . . B-3

B.3 - EFFLUENT RELEASE PERMITS . . . . . . . . . . . . . . . . B-5

B.3.1 NATIONAL POLLUTANT DISCHARGE ELIMINATION SYSTEM PERMIT . . . . . . . . . . . . . . B-5

B.3.2 PREVENTION OF SIGNIFICANT DETERIORATION PERMIT . . . . . . . . . . . . . . . . . . B-5

B.3.3 REGISTRATION OF RADIOACTIVE AIR EMISSION STACKS . . . . . B-6

B. 4 - RESOURCE CONSERVATION AND RECOVERY ACT . . . . . . . . . . . B-7

B.4.1 RCRA INTERIM STATUS ................... B-7

B.4.2 RCRA PERMITTING AND CLNSURES ............. . B-8

B.5 - SUPERFUND . . . . . . . . . . . . . . . . . . . B-12

B.5.1 SUPERFUND REQUIREMENTS ................ B-12

B.5.2 INTERIM REMEDIAL ACTIONS ................ . B-14

B.5.3 CHARACTERIZATION AND REMEDIATION OF
PAST-PRACTICE WASTE UNITS ............... B- 14

B.5.4 OPERABLE UNIT STATUS ................... . B-15

B.6 - DECONTAMINATION AND DECOMMISSIONING . . . . . . . . . . . . . B-19

B.6.1 HANFORD SURPLUS FACILITIES PROGRAM . . . . . . . . . . . B 19

B.6.2 DECOMMISSIONING EIGHT SURPLUS HANFORD REACTORS . . . . . B-20

B.6.3 PLANNED DECOMMISSIONING WORK . . . . . . . . . . . . B-21

B.6.4 REACTOR OPERATING HISTORIES . . . . . . . . . . . . . B-22

B.7 - Future Site USE STRATEgy DEVelopMent . . . . . . . . . . . B-23

B.8 - ENVIRONMENTAL MONITORING AT HANFORD . . . . . . . . . . . B-28

B.8.1 ENVIRONMENTAL MONITORING PROGRAM . . . . . . . . . . . B-28

B.8.2 CURRENT RADIOACTIVE RELEASES TO THE

B.8.3 GROUNDWATER MONITORING $\cdot \cdot \cdot \cdot \cdot \cdot \cdot \cdot \cdot \cdot \cdot \cdot \cdot \cdot \cdot \cdot \cdot \cdot \cdot \cdot \cdot \cdot$\begin{tabular}{l}
$\cdot$ \\
\hline
\end{tabular} 


\section{CONTENTS (cont)}

SECTION B: NATIONAL OR SITE-WIDE ENVIRONMENTAL AND WASTE MANAGEMENT ACTIVITIES

B.9 - COMPLIANCE ORDERS AND NOTICES OF VIOLATION . . . . . . . . . B-45

B.10 - EXTERNAL PARTICIPANTS IN HANFORD C I.EANUP . . . . . . . . . B-47

B.10.1 ROLE OF INDIANS AT HANFORD . . . . . . . . . . . . B-47

B.10.2 WASHINGTON STATE'S ROLES AT HANFORD . . . . . . . . . B-49

B.10.3 OREGON'S ROLE AT HANFORD . . . . . . . . . . . . . B-50

B.10.4 COMMUNITY RELATIONS ACTIVITIES IN SUPPORT

B. 10.5 ARMY CORPS OF ENGINEERS ROLE IN

B.11 - FUNDING FOR STATE AND TRIBAL OVEPSICHT . . . . . . . . . . B-53

B.12 - HANFORD ENVIRONMENTAL IMPACT STATEMENTS . . . . . . . . . B-57

B. 12.1 ENVIRONMENTAL IMPACT STATEMENTS IN PROGRESS . . . . . . B-57

B. 12.2 PLANNED ENVIRONMENTAL IMPACT STATEMENTS . . . . . . . . B-59

B. 12.3 PAST ENVIRONMENTAL IMPACT STATEMENTS

B. 13 - WASTE MINIMIZATION GOALS AND STATUS . . . . . . . . . . . B-64

B.13.1 PROGRAM OBJECTIVES AND SCOPE . . . . . . . . . . . B-64

B.13.2 ACCOMPLISHMENTS ................ . B-64

B. 14 - LAND, AIR, AND WATER CONTROL AT HANFORD . . . . . . . . . . B-66

B.14.1 LAND . . . . . . . . . . . . . . . . B-66

B.14.2 AIR . . . . . . . . . . . . . . . . B-69

B.14.3 WATER .................... B-69

B.15 - TIGER TEAM ASSESSMENT ACTION PLAN . . . . . . . . . . . B-70

B.16 - ATOMIC ENERGY ACT - RESOURCE CONSERVATION AND RECOVERY ACT INCONSISTENCIES . . . . . . . . . . . . B-72

B.17 - TRANSPORTATION CONCERNS . . . . . . . . . . . . . . B-74

B.18 - THE COLUMBIA RIVER'S HANFORD REACH . . . . . . . . . . . . B-77

B.19 - TECHNOLOGY NEEDS FOR ENVIRONMENTAL RESTORATION . . . . . . . . B-79 


\section{CONTENTS (cont)}

SECTION C: PROGRAM- OR WASTE-SPECIFIC ENVIRONMENTAL AND WASTE MANAGEMENT PROJECTS

C. 1 - HANFORD ENVIRONMENTAL COMPLIANCE PROJECT . . . . . . . . . . . . C 1

C.2 - SOIL COLUMN DISCHARGE ALTERNATIVES . . . . . . . . . . . C C

C. 3 - HANFORD WASTE VITRIFICATION PLANT PROJECT . . . . . . . . . . c.6

C.4 - CENTRAL WASTE COMPLEX ................... . C 7

C.5 - WASTE RECEIVING AND PROCESSING FACILITY . . . . . . . . . . C - 9

C.6 - GROUT DISPOSAL PROGRAM . . . . . . . . . . . . . . . . c-11

C.7 - 242-A EVAPORATOR .................... C C-13

C.7.1 LIQUID EFFLUENT RETENTION FACILITY . . . . . . . . . . C-13

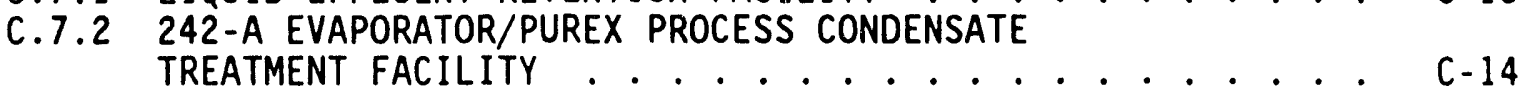

C.8 - SUBMARINE REACTOR COMPARTMENTS . . . . . . . . . . . . . . C-16

C.9 - STATE CONCERN THAT WASTE TO BE GROUTED

C.10 - ENVIRONMENTAL AND MOLECULAR SCIENCES LABORATORY . . . . . . . C-18

C.11 - IRRADIATED FUEL STORAGE AND PROCESSING . . . . . . . . . . . . c-19

C.11.1 IRRADIATED FUEL INVENTORY, STORAGE MODES,

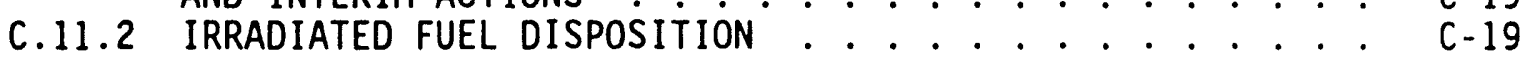

C.11.3 PUREX STATUS AND PLANS ................ . C-20

C.12 - DOSE AND HEALTH STUDIES . . . . . . . . . . . . . . . . C-22

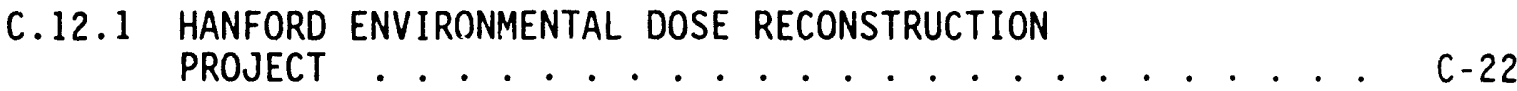

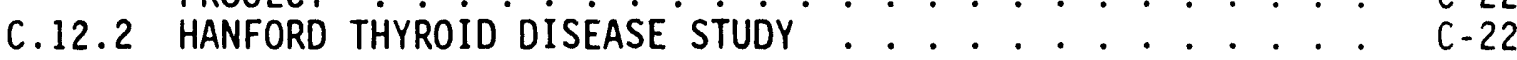

C.12.3 HANFORD WORKER MORTALITY STUDIES ...............

C.13 - WASTE TANK SAFETY BACKGROUND . . . . . . . . . . . . . . C 27

C. 14 - OfFice OF SAMPLe MANAGEMENT ROLE IN ClEANUP . . . . . . . . . . c c-30

C.15 - VENT LINES ON COLUMBIA RIVER ISLAMD . . . . . . . . . . . . c c-31 


\section{CONTENTS (cont)}

SECTION D: HANFORD SITE WASTE INVENTORIES

D.1 - WASTE MANAGEMENT UNITS . . . . . . . . . . . D D-1

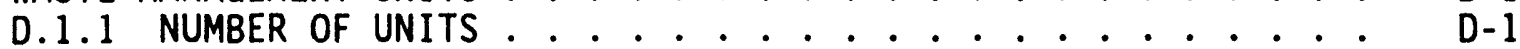

D.1.2 CATEGORIES OF UNITS .................... D-2

D.2 - RADIOACTIVE WASTE INVENTORIES ........... D-3

D.3 - WASTE TANK STATUS . . . . . . . . . . . . D-9

D.4 - 100 AREA SHALLOW LAND BURIAL OF RADIOACTIVE

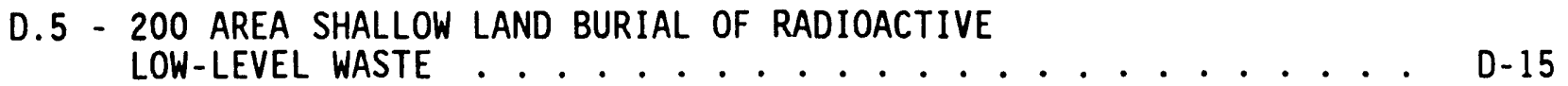

D.6 - HAZARDOUS WASTE INVENTORIES . . . . . . . . . . D-18

D.7 - CONTAMINATED FACILITIES . . . . . . . . . . D-19

[.8 - CONTAMINATED SOIL AND GROUNDWATER . . . . . . . . . . D-20

D.8.1 SOIL AND GROUNDWATER .............. D- . . . . . . .

D.8.2 OUTDCOR RADIATION AREAS ............ D-20

\section{LIST OF FIGURES}

B-1 Aggregate National Priorities List Sites for the Hanford Site ................ B-13

B-2 Tritium Concentrations in the Hanford Site Unconfined Aquifer in $1989 \ldots \ldots$. . . . . . . . . . . . 33

B-3 Contour Map of the Carbon Tetrachloride Plume . . . . . . B-36

B-4 Nitrate $\left(\mathrm{NO}_{3}\right)$ Concentrations in the Hanford Site $\ldots . \ldots$. . . . . B-37

B-5 Uranium Plumes in the 300 Area ............ B-38

B-6 Average Chromium (filtered sample) During $1990 \ldots$. . . . . B-39

B-7 Strontium-90 Plume in the 200 East Area .......... B-40

B-8 Iodine-129 Plume in the 200 West Area .......... B-41 


\section{LIST OF FIGURES (cont)}

B-9 Technetium-99 Plume in the 200 West Area . . . . . . . . B-42

B-10 Contour Map of the Carbon Tetrachloride Plume . . . . . . . . B-43

B-11 Hanford Site Land Use . . . . . . . . . . . . . . . B-67

D-1 High-Level Waste Comparison: Hanford to All DOE Sites . . . . D-5

D-2 Low-Level Waste Comparison: Hanford to All DOE Sites . . . . . D-6

D-3 Buried Transuranic Waste Comparison: Hanford to A11 DOE Sites..................... . . D-7

D-4 Stored Transuranic Waste Comparison: Hanford to All DOE Sites...................... . D-8

\section{LIST OF TABLES}

B-1 FY 1993 Field Budget Request Summary of Estimates (Environmental Management) ................ B-2

B-2 Dangerous Waste Regulations Permitting Status . . . . . . . . B-9

B-3 Routine Environmental Sample Types and Measurement

C-1 Subprojects Included in Hanford Environmental Compliance Project 


\section{LIST OF TOPICS}

100 AREA SHALLOW LAND BURIAL OF RADIOACTIVE LOW-LEVEL WASTE . . . . . D-11

200 AREA SHALLOW LAND BURIAL OF RADIOACTIVE LOW-LEVEL WASTE . . . . . . D-15

200 WEST AREA CARBON TETRACHLORIDE . . . . . . . . . . . . . . . A-15

242-A EVAPORATOR/PUREX PROCESS CONDENSATE TREATMENT FACILITY . . . . . C-14

242-A EVAPORATOR . . . . . . . . . . . . . . . . . . . . . C-13

30-YEAR CLEANUP GOAL .................... . . A-4

316-5 PROCESS TRENCHES ....................... . A-14

618-9 BURIAL GROUND . . . . . . . . . . . . . . . . . . . A-13

ACCOMPLISHMENTS . . . . . . . . . . . . . . . . . B-65

AIR . . . . . . . . B B 70

ARMY CORPS OF ENGINEERS ROLE IN HANFORD SITE CLEANUP . . . . . . . . . B-53

ATOMIC ENERGY ACT - RESOURCE CONSERVATION AND RECOVERY
ACT INCONSISTENCIES . . . . . . . . . . . . . . . . B-73

B Plant Alternative StUdies ...................... . . . A-11

CATEGORIES OF UNITS ....................... . . . D-2

CENTRAL WASTE COMPLEX ......................... . . . C-7

CHARACTERIZATION AND REMEDIATION OF PAST-PRACTICE WASTE UNITS . . . . . B-15

COMMUNITY RELATIONS ACTIVITIES IN SUPPORT OF HANFORD CLEANUP . . . . . B-52

COMPLIANCE ORDERS AND NOTICES OF VIOLATION . . . . . . . . . . . . . B-46

CONTAMINATED SOIL AND GROUNDWATER . . . . . . . . . . . . . . . . . . . D-20

CONTAMINATED FACILITIES . . . . . . . . . . . . . . . . . . . . . . . . D-19

CONTAMINATION CONTROL IMPROVEMENT PROJECT . . . . . . . . . . . . . . . . . . A A-23

CURRENT RADIOACTIVE RELEASES TO THE OFFSITE ENVIRONMENT . . . . . . . . . . . . $\quad$ B-30

DECOMMISSIONING EIGHT SURPLUS HANFORD REACTORS . . . . . . . . . . . . B-21

DECONTAMINATION AND DECOMMISSIONING . . . . . . . . . . . . . . . B-20

DOSE AND HEALTH STUDIES ....................... . . c c-22

EFFLUENT RELEASE PERMITS . . . . . . . . . . . . . . . . B-6

EMPLOYEES CONCERNS PROGRAM . . . . . . . . . . . . . . . . . . A-28

ENVIRONMENTAL MONITORING AT HANFORD . . . . . . . . . . . . . . . . . . B-29

ENVIRONMENTAL MONITORING PROGRAM . . . . . . . . . . . . . . . . . . . . . B-29

ENVIRONMENTAL IMPACT STATEMENTS IN PROGRESS . . . . . . . . . . . . . . B-58

EIIVIRONMENTAL AND MOLECULAR SCIENCES LABORATORY . . . . . . . . . . . . $\quad$ c-18

EXPEDITED RESPONSE ACTION PROGRAM . . . . . . . . . . . . . . . . . A-13

EXPEDITED RESPONSE ACTIONS . . . . . . . . . . . . . . . . . . . A-13

EXTERNAL PARTICIPANTS IN HANFORD CLEANUP . . . . . . . . . . . . . . . B-48

FEDERAL FACILITY COMPLIANCE ACT (S. 596) . . . . . . . . . . . . . A-21

FIVE-YEAR PLAN . . . . . . . . . . . . . . . . . . B-3

FY 1993 ENVIRONMENTAL MANAGEMENT FIELD BUDGET REQUEST . . . . . . . . . B-1

FUNDING FOR STATE AND TRIBAL OVERSIGHT . . . . . . . . . . . . . . . . B-54

FUTURE SITE USE STRATEGY DEVELOPMENT . . . . . . . . . . . . . . . . . B-24 
GENERAL ACCOUNTING OFFICE INVESTIGATION OF SOIL AND GROUNDWATER MONITORING GROUNDWATER MONITORING

HANFORD WORKER MORTALITY STUDIES . . . . . . . . . . . . . . . . C-24

HANFORD ENVIRONMENTAL IMPACT STATEMENTS . . . . . . . . . . . . . . . B-58

HANFORD THYROID DISEASE STUDY . . . . . . . . . . . . . . . . C-22

HANFORD ENVIRONMENTAL DOSE RECONSTRUCTION PROJECT . . . . . . . . . . . . . . . . $\quad c-22$

HANFORD SITE-SPECIFIC PLAN . . . . . . . . . . . . . . . . . B-3

HANFORD SURPLUS FACILITIES PROGRAM . . . . . . . . . . . . . . . B-20

HANFORD ENVIRONMENTAL CONIPLIANCE PROJECT . . . . . . . . . . . . . . . C

HANFORD INTEGRATED PLANHIING PROCESS .................. . . A-30

HANFORD WASTF VITRIF ICATION PLANT PROJECT . . . . . . . . . . . . . . C C-6

HAZARDOUS WASTE INVENTORIES .................... D-18

HORN RAPIDS CONTAMINATION . . . . . . . . . . . . . . . . . . A-32

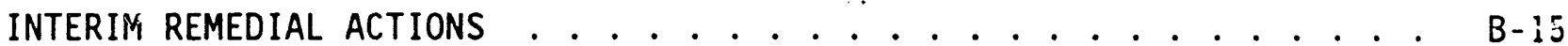

IRRADIATED FUEL INVENTORY, STORAGE MODES, AND INTERIM ACTIONS . . . . . C

IRRADIATED FUEL STORAGE AND PROCESSING . . . . . . . . . . . . . . . c c-19

IRRADIATED FUEL DISPOSITION . . . . . . . . . . . . . . . . . c-19

LAND, AIR, AND WATER CONTROL AT HANFORD . . . . . . . . . . . . . . . B-67

LAND . . . . . . . . . . . . . . . . . . . . . . B-67

LIQUID WASTES DISCHARGED TO THE GROUND . . . . . . . . . . . . . . . . . . . . . A-5

LIQUID EFFLUENT RETENTION FACILITY ................... . c-13

LIQUID EFFLUENT STUDY . . . . . . . . . . . . . . . . . . . . . . A-22

MANAGEMENT/CLEANUP PROGRAM ................... A-20

NATIONAL POLLUTANT DISCHARGE ELIMINATION SYSTEM PERMIT . . . . . . . . B-6

NEW TANKS . . . . . . . . . . . . . . . . . . . . . A-8

NEW PRODUCTION REACTOR ...................... . . . A-16

NUMBER OF UNITS . . . . . . . . . . . . . . . . . . . . . . . . . . . 0 D-1

OFFICE OF SAMPLE MANAGEMENT ROLE IN CLEANUP .............. . C-31

OPERABLE UNIT STATUS ......................... . . B-16

OREGON'S ROLE AT HANFORD ....................... . . B-51

OUTDOOR RADIATION AREAS........................ . D-20

PAST ENVIRONMENTAL IMPACT STATEMENTS THAT AFFECT THE HANFORD SITE . . . B-62

PLANNED DECOMMISSIONING WORK . . . . . . . . . . . . . . . . . B-22

PLANNED ENVIRONMENTAL IMPACT STATEMENTS . . . . . . . . . . . . . . . . B-60

PLUTONIUM FINISHING PLANT RESTART . . . . . . . . . . . . . . . . . A-18

PREVENTION OF SIGNIFICANT DETERIORATION PERMIT . . . . . . . . . . . . . . . . . B-6

PROGRAM OBJECTIVES AND SCOPE ..................... . B B-65

PUREX STATUS AND PLANS ....................... . . C-20

RADIOACTIVE WASTE INVENTORIES . . . . . . . . . . . . . . D D

RCRA PERMITTING AND CLOSURES ........................ . . . . . . . .

RCRA INTERIM STATUS .......................... . . . B-8

REACTOR OPERATING HISTORIES . . . . . . . . . . . . . . . . . . . . . . . . 
REGISTRATION OF RADIOACTIVE AIR EMISSION STACKS . . . . . . . . . . B B-7

RESOURCE CONSERVATION AND RECOVERY ACT . . . . . . . . . . . . . . . B-8

RESOURCE CONSERVATION AND RECOVERY ACT REAUTHORIZATION . . . . . . . . . A A-26

RISK ASSESSMENT FOR HANFORD WASTE VITRIFICATION SYSTEMS . . . . . . . . . . . . A A-10

ROLE OF INDIANS AT HANFORD ........................

SOIL AND GROUNDWATER . . . . . . . . . . . . . . . . . D-20

SOIL COLUMN DISCHARGE ALTERNATIVES . . . . . . . . . . . . . . . . . . C C-3

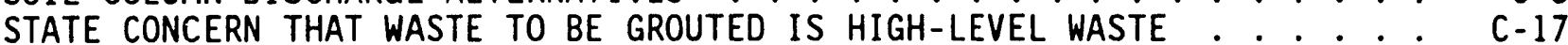

SUBMARINE REACTOR COMPARTMENTS .................. . C-16

SUPERFUND . . . . . . . . . . . . . . . . . . . . . . B-13

SUPERFUND REQUIREMENTS . . . . . . . . . . . . . . . . . B-13

TANK LEAK VOLUME . . . . . . . . . . . . . . . . . . . A-8

TANK SY-101 STATUS ................. A-9

TECHNOLOGY NEEDS FOR ENVIRONMENTAL RESTORATION . . . . . . . . . . . . .

THE DOE-HQ FIVE-YEAR PLAN . . . . . . . . . . . . . . . . . . . B-3

THE COLUMBIA RIVER'S HANFORD REACH . . . . . . . . . . . . . . . . . B-78

TIGER TEAM ASSESSMENT ACTION PLAN . . . . . . . . . . . . . . . . . B-71

TRANSPORTATION CONCERNS ........................ B-75

TRI-PARTY AGREEMENT . . . . . . . . . . . . . . . . . . . . . . . . A-1

UO3 STABILIZATION CAMPAIGN . . . . . . . . . . . . . . . . A-17

VENT LINES ON COLUMBIA RIVER ISLAND . . . . . . . . . . . . . . c-32

WASHINGTON STATE'S ROLES AT HANFORD . . . . . . . . . . . . . . . . B-50

WASTE TANK SAFETY . . . . . . . . . . . . . . . . . . . . . . . A-7

WASTE MINIMIZATION GOALS AND STATUS . . . . . . . . . . . . . . . . . . . . .

WASTE TANK STATUS . . . . . . . . . . . . . . . . . . . . . . . D-9

WASTE RECEIVING AND PROCESSING FACILITY . . . . . . . . . . . . . . . . C C-9

WASTE TANK SAFETY BACKGROUND .................... . C-27

WASTE MANAGEMENT UNITS . . . . . . . . . . . . . . . . . . . . . . D-1

WATCH LIST TANKS . . . . . . . . . . . . . . . . . . . . . . . . . A-7

WATER . . . . . . . . . . . . . . . . . . B-70

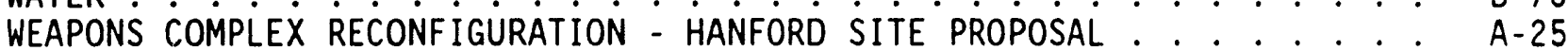




\section{ACRONYMS AND ABBREVIATIONS}

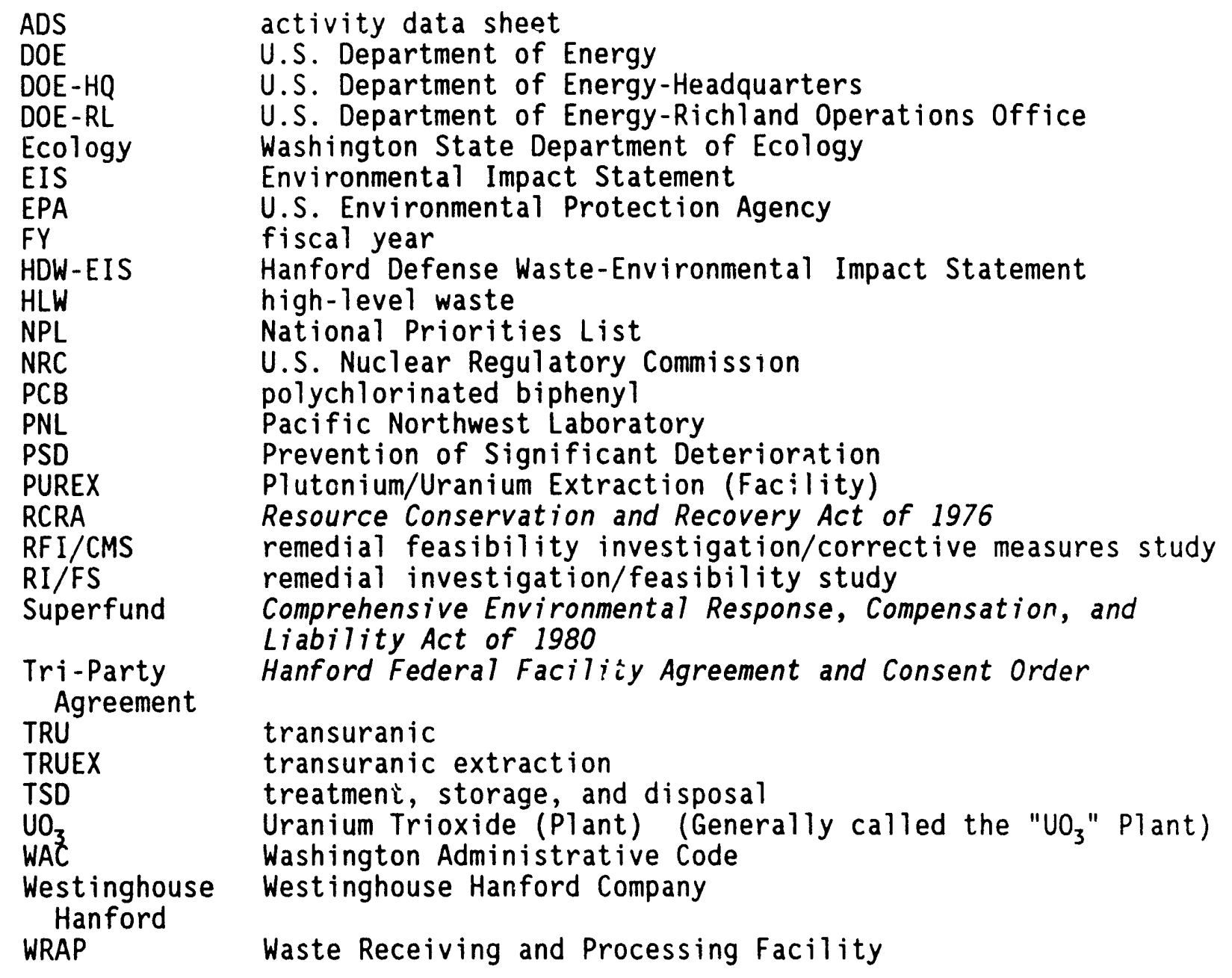




\section{A.1 - TRI - PARTY AGREEMENT}

Below are the key Tri-Party Agreement" changes proposed in May 1991. The public comment period for the proposed changes began on May 22 and ends July 5, 1991. Barring significant public comment, the proposed changes will be incorporated into the Tri-Party Agreement after then.

\section{Grout}

The milestone to complete 14 grout campaigns (M-01-00) will be delayed 27 months to accommodate additional safety requirements, resolve grout formulation issues, and verify grout solidification. Three additional enforceable milestones will be added for starting vault construction.

\section{Pretreatment}

A new date for Milestone M-02-00 will be proposed after the double-shell tank waste disposal program redefinition study. A replacement enforceable Milestone (M-02-01 due December 1991) for the completion of that study will be added. The U.S. Department of Energy (DOE) has committed to propose additional enforceable pretreatment milestones when the redefinition study is completed.

\section{Hanford Waste Vitrification Plant}

The milestone to start constructing the vitrification plant (M-03-01) will be delayed 9 months to allow completion of the double-shell tank waste disposal program redefinition study. The vitrification hot startup date of December 1999 is unchanged for now.

\section{Single-She11 lank Iiterim Stabilization}

Interim milestones for interim stabilization of single-shell tanks will change. The major milestone, to complete the interim stabilization of all but the two high-heat tanks by September 1995, is unchanged at present. Additional target dates will be added to the Tri-Party Agreement Action Plan Work Schedules for the start of stabilization of individual tank farms in 1991 and 1992.

"Hanford Federal Facility Agreement and Consent Order, as amended, 1990, Washington State Department of Ecology, U.S. Environmental Protection Agency, U.S. Department of Energy, 01 ympia, Washington. 


\section{Single-Shell Tank Waste Characterization}

Two milestones for tank sampling (M-10-04 and M-10-06) will change due to tank safety issues. Milestone M-10-05 will be redefined to cover the preparation of an integrated waste sampling plan (covering samples of $10 \mathrm{mrem}$ per hour or greater) by March 1992. After that, DOE will propose adjustments to other waste characterizaicion interim mi iestones. No changes to the September 1998 major milestone are proposed. A new enforceable milestone will be added to restore rotary mode sampling capability for Hanford tank wastes by September 1992.

\section{Past Practices}

Several milestones covering past practice remedial action activities will change. A number of new enforceable milestones will be added and a few milestones will be deleted. These changes support a move toward a new method of studying and cleaning up old waste sites.

\section{B Plant Part B Permit}

Milestone M-20-21 will be redefined because of uncertainties about the future of $B$ Plant. A new enforceable milestone to submit of either a closure plan or a permit application for B Plant by January 1992 will be established.

\section{Single-Shell Tank Groundwater Monitoring Wells}

Milestones M-24-07 and M-24-00 (for calendar year 1990 only) will be extended 280 days to account for the drilling delays that began in November 1989.

\section{New Double-She11 Tanks}

New enforceable milestones (M-31-00) are being proposed for up to four new double-shell tanks. The double-shell tanks may be needed to ensure adequate storage capacity for Hanford tank wastes (see Section A.4.3).

\section{Liquid Effluent Treatment and Disposal}

A new section will be added (13.0) that will set forth the authorities and responsibilities for the treatment and disposal of liquid effluents to the soil at Hanford. New enforceable milestones are also proposed under Milestone M-17-00 to support actions addressed in this section. The ne: section will guide the development of several new enforceable milestones dealing with 33 effluent streams. 


\section{Funding Language}

Paragraph 139 of the Tri-Party Agreement is proposed to be modified to clarify the involvement of the Washington State Department of Ecology (Ecology) and the U.S. Environmental Protection Agency (EPA) in the DOE process of obtaining funds for the work covered by the Tri-Party Agreement.

\section{Other Changes}

Paragraphs 112 and 114 of the agreement wil] be modified to extend the 7-day review period for change packages and for beginning dispute resolution. 


\section{A.2 - 30-YEAR CLEANUP GOAL}

The DOE has set a goal to "clean up and restore the environment at DOE's nuclear sites by 2018." This has always been a goal, not a contract. In the original negotiations with the State and Tribal Government Working Group, the group asked for a 30-year cleanup. Recognizing we have many uncertainties about some of our waste types and how to clean them up, DOE agreed to adopt the 30-year target as a goal. The 1990 Five-Year Plan reaffirmed the goal.

Can that goal be reached? Yes, but there are obstacles to overcome.

There is the question of standards. How clean is clean? We use the term "cleanup" very loosely. What cleanup means is that the DOE's facilities come into compliance with environmental laws and standards. Not all the standards we need have been agreed upon. At both the local and the national level we must develop a consensus of how clean is clean.

There is the question of defining the problem. A large part of DOE's cleanup will be the effort to und stand the problem. What are the contaminants? Where are they? How have they changed? How do they move? In what way do they affect people or the environment? How can they be neutralized or inritained?

There is the question of technology. In many cases we need to deverop the methods and equipment needed to do our cleanup work.

There is the question of money. It will tike many billions of dollars to clean up the DOE's sites. Those billions of dollars must come from the taxpayers. Therefore, the DOE's ability to clean up depends on the willingness of taxpayers to pay for it.

So although DOE has set a goal to clean up and restore by 2019 there are many things that others must do to help. Private industry, state and local governments, and most importantly, the public must stand behind this effort in order to reach that goal. 


\section{A.3 - LIQUID WASTES DISCHARGED TO THE GROUND}

Since 1944 , large quantities of liquids containing radionuclides and hazardous chemicals have been discharged to the ground surface or subsurface. A large portion of these discharges have been cooling water, much of which is uncontaminated under normal conditions. Solid wastes, such as failed equipment, tools, and protective clothing containing radionuclides and hazardous materials, have also been buried in the ground. These activities have been previously reported in publicly available documents; however, new interest in this information has resulted from recent media coverage.

From 1944 to 1989 , a total of approximately 1.67 billion $\mathrm{m}^{3}$ (444 billion gallons) of 1 iquid wastes (predominately water), containing $678,000 \mathrm{Ci}$ of radionuclides, were discharged to the soil. Of this, approximately $462 \mathrm{ML}$ (122 Mgal), containing $214,000 \mathrm{Ci}$, was waste that had previously been stored in or routed through single-shell tanks. This includes wastes that leaked from single-shell tanks and wastes that were intentionally discharged. Most of the intentional tank waste discharges occurred from 1944 to 1958, with some (1ess than 10 percent) through 1966. Approximately $625,000 \mathrm{~m}^{3}$ of solid wastes, containing 4.9 million curies, have been buried in the ground.

The key radionuclides considered are those with half-lives long enough (greater than 10 years) and in quantities great enough to be of concern in waste disposal and cleanup. Radionuclide inventories include tritium, ${ }_{14}$ carbon, ${ }_{90}$ strontium/ 90 yttrium, 99 technetium, ${ }_{129}$ iodine, ${ }_{137}$ cesium/ $/{ }^{137}$ barium, ${ }_{128}^{238}$ uranium, and transuranics (TRU). Inventories for tritium, 99 technetium, and ${ }^{129}$ iodine are not included at all in most of the data sources. However, inventories of these isotopes were estimated by calculating the quantity produced during fuei irridiation and distributing them among the various waste types based on process knowledge.

Early site records are not complete. No solid waste volumes were recorded until the late 1950's and no radionuclide inventories for any of the discharges were recorded until the late 1960's. As a result, some of the numerical values are estimates derived from a variety of sources. The estimates for radionuclide inventory and waste volume provided are believed to be reasonable, but have a significant level of uncertainty associated with them.

A material balance of key radionuclides shows that approximately 99 percent of the key radionuclides produced onsite are now in the singleshell and double-shell tanks; cesium and strontium capsules; irradiated fuel storage in the 100, 200, and 400 Areas; and isotopic heat source storage in the 300 Area. The remaining l percent is contained in solid wastes buried in the ground, stored solid wastes, and liquid wastes that were discharged to the ground.

From 1945 to 1966, some tank wastes were intentionally discharged to the ground through cribs and specific retention basins. The greatest volume (68.5 Mgal) came from spent fuel reprocessing in B Plant and T Plant from 1944 to 1956. Nearly $41 \mathrm{Mgal}$ was from uranium recovery in U Plant from 1952 
to 1957 . Equipment decontamination and 300 Area laboratory operations (wastes routed through tanks for discharge to soil) resulted in the discharge of $11.2 \mathrm{Mgal}$ from 1960 to 1966.

Approximately 1 Mgal of tank waste was inadvertently discharged to the ground as a result of leaks and spills. Approximately $197 \mathrm{Mgal}$ of evaporator condensate has been discharged to the ground as a result of processing of tank waste through avaporators to reduce the volume. This condensate is predominately water and contains only a very small amount of radionuclides. These disposal sites are on the 200 Area plateau, in and near the 200 East and 200 West Areas.

Additional information on liquid discharges to the ground can be found in DOE/RW-0006, Rev. 6, Integrated Data Base for 1990, October 1990. Additional information on tank waste discharges to the ground can be found in WHC-MR-0227, Tank Wastes Discharged Directly to the Soil at the Hanford Site, Apri1 1991. 


\section{A.4 - WASTE TANK SAFETY}

\section{A.4.1 WATCH LIST TANKS}

Safety concerns were raised in early 1990 ajout the potential for chemical explosions in some of the Hanford Site's tanks. The explosions or rapid burning of gases could result from ferrocyanide-nitrates/nitrites, hydrogen-nitrous oxide combustion, or high organic contents. The total number of tanks involved is 53. Some tanks are in more than one category of concern.

Some tanks received ferrocyanide in the 1950's. Twenty-four tanks may have received enough that the ferrocyanide mixed with the sodium nitrate/ nitrite could explode if heated to high enough temperatures. Eight tanks contain solid salts with high organic material content, which are potentially flammable. In addition, one single-shell tank requires water to be added to control high decay temperatures.

Experimental work to define the minimum reaction temperature of various ferrocyanide-nitrate/nitrite mixtures and potential catalysts is ongoing, and tank temperature monitoring has increased. The potential for a ferrocyanide explosion is very low for the conditions in the tanks now. An explosion requires both the right ferrocyanide-nitrate/nitrite mixtures and high temperatures. Assuming the right chemical mixtures could be present, the highest temperature for tanks that contain ferrocyanides is $135^{\circ} \mathrm{F}$ compared with the temperature of concern of at least $400^{\circ} \mathrm{F}$. Furthermore, the heat source in the tanks continues to diminish as the radionuclides decay. Recent experiments in Los Alamos have indicated the explosion potential is even lower than earlier assumed.

Another concern is that the maximum credible accident (a ferrocyanidenitrate explosion in a single-shell tank) used in the Hanford Defense WasteEnvironmental Impact Statement (HDW-EIS) may understate the consequences. Secretary of Energy Watkins committed to do a supplement to the HDW-EIS to address waste tank safety issues, including redoing the maximum credible accident analysis. Plans are under way to sample the vapor space in ferrocyanide Tank 104-BY. A core sample can be obtained after successful sampling of the tank's vapor space. The core sample will help reevaluate the maximum credible accident.

Twenty-three tanks have the potential to build up combustible mixtures of hydrogen and nitrous oxide gas. Of particular concern is Tank 101-SY, which exhibits gas buildup and periodic release. The next two tanks of concern are $103-\mathrm{SY}$ and 104-AN. The other 20 tanks show significantly less gas-generating activity.

"Final Environmental Impact Statement--Disposal of Hanford Defense HighLevel, Transuranic and Tank Wastes, DOE/EIS-0113, U.S. Department of Energy, Washington, D.C., 1987. 
Interim operational controls are in place on all 53 'watch list' tanks to reduce the potential for generating an ignition source. These safety concerns and the actions under way or planned are receiving numerous reviews by internal and external review groups including U.S. Department of EnergyHeadquarters (DOE-HQ) special teams and consultants, the Defense Nuclear Facilities Safety Board, the Advisory Committee on Nuclear Facility Safety, the General Accounting Office, and Washington State.

Publ ic 1aw 101-510, Section 3137, "Safety Measures for Waste Tanks at Hanford Nuclear Reservation" (also known as the Wyden bill) was passed in December 1990. It requires additional plans to be submitted. This bill also requires "continuous" monitoring of all watch list tanks. The Secretary of Energy submitted a plan to Congress in May.

\section{A.4.2 TANK LEAK VOLUME}

In addition to the possibility of explosions, the volume of waste that has leaked from the single-shell tanks is an issue. The controversy centers around Tank 241-A-105, to which cooling water was added after 1963 when the tank was declared a leaker. The cooling water volume was never part of the estimated leak volume. Much of the cooling water evaporated because of the radiolytic heat in the tank. Calculations have been made and are under review to estimate the total amount of liquid that may have leaked from this tank.

In addition, a report was recently issued on the amount of single-shell tank waste directly discharged to cribs usually via 'cascading' techniques. The present estimate is that about $122 \mathrm{Mgal}$ of single-shell tank wastes were purposefully disposed of to the ground from 1946 to 1966 via cribs and trenches. issues.

See Sections C-13 and D-3 for more information about waste tank safety

\section{A.4.3 NEW TANKS}

$\mathrm{N}$ it only is the Hanford Site very close to running out of double-shell tank suace to support routine waste discharges; new tank space is also needed to interim treat tanks with safety problems, like Tank 101-SY. There is a growirg awareness and concern about waste compatibility, as a result of the investigations on Tank 101-SY (which had a variety of wastes added to it), resulting in a strong desire to be able to segregate certain types of waste.

The DOE has recognized the need for new tanks. We are trying to 'validate' for a fiscal year (FY) 1993 line item for a new tank farm. In we are successful, that new tank farm would be operational in FY 1998. 


\section{A.4.4 TANK SY-101 STATUS}

Tank 101-SY has experienced a 3- to 9-in. rise of the crusted surface over a 2- to 4-month period followed by release of gases and surface fall during several hours or days.

The latest venting (which started "window C") occurred the evening of May 16 and lasted into May 1, th. At the end of approximately 12 hours the surface dropped more than $10 \mathrm{~cm}$ (4 in.). There was also fairly rapid drop in temperature. The remaining vertical crust drop (a $12.7 \mathrm{~cm}$ [5-in.] drop is required before the vent can be called "complete") happened over a longer period.

A special joint Test Group was established to assure there would be no problems this cycle, known as "window C." Five separate safety assessments and an environmental assessment were required. Many activities were successfully accomplished during the window, including installing a TV camera and light system, auger crust sampling from four separate locations, surface penetrometer, push-mode full core sampling, and installation of a radar level gage. More samples than planned were taken due to the extreme efficiency of the crews.

It appears that there was also a release of ammonia during this event. The ammonia smell was strong enough that the tank farm workers had to put on masks for a short time.

The August 5, 1990 venting generated $96.3 \mathrm{~m}^{3}\left(3,400 \mathrm{ft}^{3}\right)$ of gas in a 3 -hour period, and the October 24,1990 venting generated $198 \mathrm{~m}^{3}\left(7,000 \mathrm{ft}^{3}\right)$ of gas in a 5-minute period. Both times the gase: :ented through filters and there was no release of radioactivity to the environment.

The February 1991 venting did not follow the normal release pattern. The temperature profile did change and the surface crust level dropped, but there was a very small volume of gas released (less than $2.8 \mathrm{~m}^{3}\left[100 \mathrm{ft}^{3}\right]$ ), and the release occurred over a l-week time period. This more closely resembles other gas-generating tanks, which have frequent but very small gas releases. This is a much safer situation than one large release. The frustrating aspect is that since this was a change in the tank's behavior, planned activities for sampling and measurements also were affected.

The window for sampling opened February 20; however, due to the differences with previous events, the window was not DECLARED open unt 11 March 5 th (after detailed evaluation of the instrument readings). The window closed March 18th. 


\section{A. 5 - RISK ASSESSMENT FOR HANFORD WASTE VITRIFICATION SYSTEMS}

Westinghouse Hanford Company (Westinghouse Hanford) staff, with strong support from Pacific Northwest Laboratory (PNL), are studying the technical, regulatory and programmatic uncertainties and resulting risks with the Hanford Waste Vitrification Program. The study is formally called the Hanford Waste Vitrification Systems Risk Assessment. The assessment includes evaluations of both double- and single-shell tank waste remediation activities. The study began in September 1990 at the request of the DOE-HQ.

The request resulted from recent events, which raised questions about the technical suitability of waste pretreatment and vitrification plans for Hanford wastes. These events included waste composition uncertainties, illustrated by hydrogen generation in double-shell tank wastes; lack of operational data from the Savannah River vitrification plant; and undetermined scope of potential future vitrification missions such as the processing of single-shell tank wastes.

Preliminary findings and potential mitigating strategies were developed using existing information and presented in December and January. Detailed technical assessilents were completed in April as input to the risk analysis. Uncertainties were identified, and the degree of uncertainty for each program activity was quantified as data for a computer network model of the program. The model logic was verifiej for accuracy and all data were checked in preparation for performing the risk calculations. Initial results were generated using the conputer model; these results were reviewed by a peer review panel in preparation for issuing the draft Risk Assessment final report for review.

Thie computer risk modeling and analys is activities have proven to be more complex than originally estimated, and have taken longer to complete. As a result, the draft report will be issued for review in early June, approximately two weeks later than planned. However, this delay is not expected to delay issuing the final approved report by the end of August.

Issues raised in the Risk Assessment are being addressed in the activities to redefine the strategy for disposal of double-shell tank wastes. A proposed strategy will be provided to the U.S. Department of Energy-Richland Operations office (DOE-RL) in September. 


\section{A.6 - B PLANT ALTERNATIVE STUDIES}

The B Plant was built in 1943 to recover plutonium from irradiated fuel. We are now upgrading the facility to operate as a pretreatment facility. But there are questions about B Plant's ability to meet current safety and environmental requirements. In fact, we have real questions about whether B Plant will ever be able to be permitted under modern regulations. As a result of these developments, we are evaluating other options for pretreating double-shell tank wastes.

The options are:

- B Plant pretreatment of double-shell tank waste

- Double-shell tank waste pretreatment without transuranic extraction (TRUEX):

- In B Plant

- In Plutonium/Uranium (PUREX) Plant

- In Hanford Waste Vitrification Plant.

- B Plant pretreatment of neutralized current acid waste only

- New pretreatment facility for double-shell tank wastes

- New pretreatment facility for double- and single-shell tank wastes.

The evaluations are scheduled for completion in August 1991, concurrent with completion of the Hanford Waste Vitrification Systems Risk Assessment.

The present strategy for disposing of double-shell tanks wastes calls for the waste to be pretreated. Engineering studies in the early 1980's recommended using $B$ Plant for pretreatment. The record of decision from the HDh-EIS pointed this way too. A 1989 study that assessed options for pretreating the waste also recommended that 244-AR Vault be used with $B$ Plant to pretreat waste. The DOE-RL accepted the recommendation in November 1989. This is our current plan. Further, the present baseline calls for pretreatment of neutralized current acid waste through a settle-decant and sludge washing process in AR Vault with filtration and ion-exchange processes in B Plant. Post-neutralized current acid waste types may undergo selective sludge washing in the AR Vault. The TRU wastes would be removed using the TRUEX process, to be installed in B Plant. Processes for the destruction of organics and removal of cesium from complexant concentrates waste would also be installed in B Plant.

"244-AR Vault Compliance with DOE Order 6430.1A and other codes, standards, and regulations (Task 3), SAIC 89-4-3-4, Science Applications International Corporation, Richland, Washington, April 1989. 
The assessment of pretreatment options recognized potential difficulties in acquiring a dangerous waste permit for B Plant. Its cells are not 1 ined and the cell drain header may not be adequate as a secondary containment. Most recently, the preliminary findings from the Hanford Waste Vitrification Systems Risk Assessment called the permitting of B Plant a "substantial risk" to the vitrification program. The study cited the secondary containment issues associated with cell liners, cell drain header, and embedded piping. While tests show using TRUEX to pretreat neutralized cladding removal waste could produce highly corrosive acids which are incompatible with existing piping and tank systems, more recent work shows that it may be possible to limit the adverse impacts to a few cells. 


\section{A.7 - EXPEDITED RESPONSE ACTIONS}

\section{A.7.1 EXPEDITED RESPONSE ACTION PROGRAM}

An expedited response action is a way to speed up the cleanup of old waste sites. Such actions can be taken at those sites where a benefit can be gained by starting action earlier. Two types of expedited response actions can be conducted, depending upon the immediacy of the situation at the waste site. If the risk to human health or the environment is immediate and the need for a response is urgent, the response is called "time critical." Typically, the planning period for these actions must be less than 6 months. The law allows a "non-time critical" expedited response action when the immediacy of the response is not thought to be crucial and it is acceptable to plan for more than 6 months before starting the action.

To date, we have selected three sites for expedited response actions. A description and status of each follow. In addition, we are considering other sites for expedited response actions in the future. These actions include removing old reactor effluent lines, treatment of contaminated groundwater in the 100 and 300 Areas, and remediation of other solid waste burial grounds, including those with TRU wastes.

\section{A.7.2 618-9 BURIAL GROUND}

The 618-9 burial ground contains drums of an organic solvent possibly containing uranium. These drums were disposed of at the site, near the 300 Area, during the 1950 's.

An expedited response action is under way at this burial ground to remove any solvents remaining in the drums and in the soil around the drums. This will limit the source of contamination that could be released to the environment or possibly contaminate the groundwater.

This expedited response action is being conducted in two distinct phases. The first phase involved excavating the soils around the drums and removing the liquid contents of the drums. The second phase will address treating any contaminated soils we find.

The first phase actions have all been completed. The entire trench at the 618-9 burial ground has been excavated. A total of 120 drums were found, 42 contained contaminated liquids. In addition, a large amount of debris (pipes, process equipment, badly corroded drums, and miscellaneous construction debris) was al so unearthed. Approximately $5,678 \mathrm{~L}(1,500 \mathrm{gal})$ of 1 iquids was recovered. All liquids removed from the buried drums have been sampled and sent for laboratory analysis. The initial results received reported a hexone matrix containing iron and copper.

The EPA has tentatively agreed to allow shipment of the recovered solvents to the offsite incinerator used for Hanford hazardous waste disposal. 
In addition, trench debris may be taken to the low-level burial ground if it fits the accepted criteria.

The soil sampling plan has been finalized and soil sampling began in May. Results from the soil sampling are still pending.

An expedited response action proposal is in preparation which will evaluate potential soil treatment processes. Soil treatment can proceed after regulatory and public review. If determined to be necessary, soif treatment would then be conducted early next year.

\section{A.7.3 316-5 PROCESS TRENCHES}

The 316-5 Process Trenches are an active liquid disposal facility in the 300 Area. The site is near the western boundary of the 300-FF-1 operable unit, about $300 \mathrm{~m}$ west of the Columbia River. The site contains two trenches that have received radioactive as well as hazardous chemical laboratory waste from the 300 Area.

The discharge of hazardous wastes to the trenches ended in 1985 but up to $3.8 \mathrm{ML}$ ( $1 \mathrm{Mgal}$ ) of water from heating and cooling systems in the buildings in the 300 Area goes to the trenches every day. Efforts are under way to reduce and ultimately eliminate the wastestream. The trenches went into service in 1975. The sediment in the trenches contains small quantities of uranium, cadmium, nickel, lead, mercury, copper, chromium, silver, trichloroethylene, and chloroform.

Most of the contaminants are in the top $2 \mathrm{ft}$ of soil in each trench, though some have migrated down into the groundwater and from there into the Columbia River. The concern is that the clean water now going to the trenches can drive the contamination further into the soil and ultimately to the groundwater and the river.

So far, the levels of cortamination entering the river have been low and do not threaten the water quality of the river. The expedited response action at this site will remove most of the existing contaminants in the soil. This will reduce the volume of contaminants that could reach the river.

An engineering evaluation and cost analysis has been completed. It details the decision-making process used to select the proposed actions. This proposal is now undergoing public review. Following the public review, EPA will issue an action memorandum directing the removal of the contaminated materials from the bottom of the active portions of the trenches. The engineering evaluation and cost analysis describes the method of excavation and placement of the contaminated materials.

The removal and consolidation are scheduled to begin this July. 


\section{A.7.4 200 WEST AREA CARBON TETRACHLORIDE}

Carbon tetrachloride contaminates the groundwater and the soils above the groundwater zone near the Plutonium Finishing Plant in the 200 West Area. It is estimated that the bulk of the carbon tetrachloride came from, and remains near, three specific disposal sites near the plant.

We will conduct an expedited response action to remove the bulk of carbon tetrachloride from the soils above the groundwater. This will remove the source of contaminants responsible for the groundwater carbon tetrachloride plume.

All Phase I site characterization activities, including a vapor extraction test, have been completed. Results from the test are very encouraging. They indicate a radius of influence of more than $200 \mathrm{ft}$ and averaging more than $200 \mathrm{ppm}$ carbon tetrachloride extracted (which corresponds to a removal of approximately 200 lbs of carbon tetrachloride per week at the system flow rate of $300 \mathrm{ft}^{3}$ per minute). Based on this information, a vapor extraction system could be designed which could remove several tons of carbon tetrachloride per year.

Results from the site characterization activities were used to prepare the Environmental Response Action proposal, which was submitted to DOE and the regulators on June 17, 1991. In addition, the existing vapor extraction system is being modified so that the Phase I remediation activities can begin in mid-September of this year. 


\section{A.8 - NEW PRODUCTION REACTOR}

The DOE-HQ plans to build a new facility to produce tritium for nuclear weapons. The Washington Public Power Supply System's WNP-1 Reactor is one facility the DOE is considering.

The DOE issued a draft EIS, which was prepared by Argonne National Laboratory, in April (see Section B.12.1). Testimony at the Richland and Spokane public hearings largely supported conversion. Testimony in Spokane, Seattle, and portland was mixed to negative. The DOE is required to respond to all comments in the final version of the EIS.

From a technological standpoint, conversion is highly feasible. However, some institutional issues need to be addressed. Since it was originally designed to produce electricity, there is the potential for some $\$ 400$ million in annual revenue. The distribution of this revenue is one of the several institutional issues that would need to be addressed.

Conversion of the plant is a continuing political issue. In February, Energy Secretary Watkins stated in a letter to Senator Nunn that DOE will consider any of the technologies at any of the sites. The other two technologies under consideration are a heavy water reactor and a modular high temperature gas reactor, and the other two sites are Savannah River and Idaho Falls.

In early May, the House Armed Services Committee, led by two South Carolina representatives, amended the U.S. Department of Defense authorization bill to include a "sense of the House" resolution that the new production reactor should be sited at Savannah River. In the House Rules Committee, Congressman Morrison of Washington and Stallings of Idaho tried to derail the resolution, but failed.

Westinghouse Hanford has been asked to work on a set of technical questions to provide information for use in the record of decision. Westinghouse Hanford is working with PNL, which has responsibility for the development of the lithium target needed to produce tritium, in the areas of reactor core application design, safety considerations, and project planning.

Studies have shown that with the current state of completion and preservation, conversion of WNP-1 has cost and schedule advantages over other alternatives. Specifically, the plant could be completed in less than 6 years at a cost of about $\$ 2.5$ billion. The other alternatives would cost about twice as much, and take longer to complete. 


\section{A.9 - U03 STABILIZATION CAMPAIGN}

Uranium Trioxide $\left(\mathrm{UO}_{3}\right)$ Operations plans to conduct a stabilization run in the fall of 1991 to convert remaining uranyl nitrate hexahydrate to $\mathrm{UO}_{3}$ powder. Uranyl nitrate hexahydrate is corrosive. It is considered a potential environmental threat for long-term storage. It is slated to be converted to the relatively low hazard, stable, dry powder form. About 200,000 gal of the material will be calcined over a 4-week period. The $\mathrm{UO}_{3}$ will be temporarily stored in specially designed T-hopper containers, awaiting a decision from DOE to reuse the material or place it in long-term storage.

$\mathrm{Pl}$ ans for future operation of $\mathrm{UO}_{3} \mathrm{Pl}$ ant, beyond the stabilization run, await a record of decision about whether remaining $K$ basins' fuel will be processed at PUREX.

The $\mathrm{UO}_{3}$ Operations, Engineering, and Maintenance personnel are in the process of completing key restart tasks which include:

- Reactivating process instrumentation and equipment

- Installing and testing of upgrades to ensure the process is run safely and efficiently

- Training and certifying operating staff

- Completing prestart requirements as set forth by the formal Readiness Review Board, including reviewing and updating environmental documentation as needed.

Facility restart actions are governed by approved Integrated and Maintenance Outage schedules. The readiness review process, with oversight from Westinghouse Hanford safety organizations and DOE-RL, is expected to be completed in September 1991. Final approval to start the facility will require concurrence of Westinghouse Hanford management and DOE-RL.

For 6 months after the stabilization run, the plant will transition to a standby mode. The plant will remain on standby from spring 1992 until the EIS for disposition of remaining irradiated fuel is complete. If the PUREX option is chosen, the plant would begin a 2- to 3-year ramp-up period in parallel with PUREX. Potential alternate uses for the facility are under evaluation. 


\section{A.10 - PLUTONIUM FINISHING PLANT RESTART}

The Plutonium Finishing $\mathrm{Pl}$ ant is $\mathrm{planning}$ to resume operations at the Plutonium Reclamation Facility, one of two major processing areas within the plant. Energy Secretary Watkins directed in October 1990 that the Plutonium Finishing Plant would operate to stabilize scrap materials and prepare inem for long-term storage, and to support material cleanout activities needed to improve the overall safety posture of the facility. The plant is expected to be transferred from DOE-HQ Defense Programs to Environmental Management in FY 1992. The Plutonium Finishing Plant's FY 1991 operating budget is $\$ 78.5$ million, and 437 people are employed there.

The Plutonium Reclamation Facility processes and stabilizes scrap plutonium materials, which are currently stored at the Plutonium Finishing Plant, to produce plutonium nitrate. Restart will follow resolution of two environmental issues.

The first environmental issue involves the S-302-A Catch Tank. This catch tank serves as containment for the 151-S Diversion Box. Liquid wastes from Plutonium Finishing Plant are transferred from the 241-Z facility to Tank 244-TX. From 244-TX, wastes are transferred to Tank 102-SY. The secondary containment for the transfer 1 ine from 244-TX to 102-SY drains to the 151-S Diversion Box. A leak in the S-302-A Catch Tank was identified by a drop in liquid level measurements. A repair of this leak was attempted, but was unsuccessful. Activities are now under way to replace the catch tank. The replacement tank should be ready for beneficial use by September 1991 . Restart cannot proceed until this repair is complete because waste volumes generated during operation would quickly fill Tank 244-TX and need to be transferred to Tank 102-SY.

The second issue involves potentially radioactive liquid effluents discharged to the $216-\mathrm{Z}-20 \mathrm{crib}$. In response to public concerns about the continued discharge of liquid effluents to the soil column, a new Tri-Party Agreement milestone was developed. This milestone includes interim operating restrictions for the 216-Z-20 Crib. Before the stabilization run can begin, we will be required to restrict flow to less than $606 \mathrm{~L}$ (160 gal) per minute and obtain EPA and Ecology approval on a wastewater sampling and analysis plan.

Additional requirements include:

- Implement closed-10op cooling in the plant by January 1994

- Cease discharges to the crib by June 1993

- Provide an inventory of TRU radionuclides discharged to the crib by July 1991

- Evaluate the need for accelerated treatment of TRU material in the wastewater by July 1991. 
This proposed milestone is in a 45-day public comment period.

Activities are under way to resolve these environmental issues, with restart tentatively planned for September 1991 . 


\section{A.11 - GENERAL ACCOUNTING OFFICE REVIEW OF U.S. DEPARTMENT OF ENERGY'S WASTE MANAGEMENT/CLEANUP PROGRAM}

The General Accounting Office is evaluating DOE's Environmental Restoration and Waste Management program as part of the Resource Conservation and Recovery Act of 1976 (RCRA) reauthorization process (see Section A.16). Aspects of the program that General Accounting office intends to evaluate include:

- The pros and cons of transferring responsibility for cleanup to a central entity

- Regulatory compliance matters, such as RCRA/Atomic Energy Act inconsistencies and DOE's self-regulation of radioactive wastes (see Section B.16)

- DOE's cleanup strategies discussed in its Five-Year Plan, as compared with lessons learned from EPA's Superfund (Comprehensive Environmental Response, Compensation, and Liability Act of 1980) program

- Hanford's "flagship cleanup site" as a possible case study of DOE's management efforts

- DOE's waste minimization efforts (see Section B.13).

The General Accounting Office's findings will likely be used as a technical resource for drafting RCRA reauthorization bills. 


\section{A.12 - FEDERAL FACILITY COMPLIANCE ACT (S. 596)}

Congress is again considering the Federal Facility Compliance Act. This law would require Federal facilities to comply with "Federal, state, interstate and local substantive and procedural requirements" for solid waste disposal and management. For the purposes of enforcement, it would expressly waive the Federal government's immunity. It would subject employees, officers, and agents of the United States to criminal penalties under "any Federal, State solid or hazardous waste law." Contractors to Federal agencies also would be at risk.

The major concern of those who oppose the bill is that it would allow various constituencies to reset the national priorities for cleanup of DOE facilities. Attempts were made in the last Congress to lessen the bill's detrimental effects, but all of those efforts failed.

The House passed this bill by overwhelming margins in 1989 and 1990. The bill is earmarked for fast-track treatment by the House this year. Congressman Dinge 11 supports the bill and chairs the committee from which it stems. In the House, the bill number is H.R. 2194.

Senate Majority Leader Mitchell introduced the bill, S. 596, in the Senate this year. It is identical to last year's. It was reported by the committee on May 15. If the bill reaches the Senate floor, it has a good chance of passing. However, there is also Senate opposition, which centers on basic concern about the effect of the bill on the ability of Federal agencies to manage DOE and Defense department cleanup programs and over congressional control of appropriated funds. This opposition may be strong enough to force a compromise, but supporters have so far given little indication of their willingness to negotiate.

The Administration is working on a compromise that probably will be coordinated with Senators Johnston, Nunn, and Warner. 


\section{A.13 - LIQUID EFFLUENT STUDY}

The Liquid Effluent Study effort began in July 1989 in response to early public comments on the Tri-Party Agreement about effluent discharges on the Hanford Site. The purpose of the study was "to provide detailed characterization of Hanford Site liquid effluents, assess waste disposal sites and groundwater contamination in area wells, and evaluate the potential for contaminant migration within receiving soil sites."

The DOE-RL and Westinghouse Hanford have negotiated liquid effluent amendments to the Tri-Party Agreement with EPA and Ecology. These amendments result, in part, from regulators' comments on the Liquid Effluent Study reports. The amendments include: (1) interim operating restrictions for the streams the EPA categorized as high-priority, (2) plans for future sampling and analysis of the streams, and (3) a method to assess the impact of liquid effluent discharge on the receiving sites. At the same time, a separate agreement about permitting was reached with Ecology. As part of the agreement, milestones were set for submitting best available technology/ 240 engineering reports for Phase I and II streams and plans for addressing the "miscellaneous" streams. The parties also agreed to establish additional milestones related to operations, treatment, and disposal of the 33 streams in negotiations to take place by September 1991.

To prepare for the upcoming negotiations, Westinghouse Hanford is preparing a liquid effluent program management plan. This plan will be used as the basis for the negotiations. The program plan will include:

- Overall, integrated liquid effluent management strategy

- Individual management action plan for each of the 33 streams

- A quality assurance program $\mathrm{plan/project} \mathrm{plan} \mathrm{to} \mathrm{address} \mathrm{data}$ quality assurance requirements

- Schedule and funding requirements for the evaluation/development of the "impact assessment" methodology

- Strategy and schedule for addressing the "miscellaneous" streams (not Phase I nor Phase II streams)

- Item-by-item resolution of the regulator comments on the Liquid Effluent Study reports.

"Waste Stream Characterization Report, WHC-EP-0287, Vols. 1 through 4; Liquid Effluent Study Project Plan, WHC-EP-0275, Rev. 2; Liquid Effluent Study Characterization Data, WHC-EP-0355; Liquid Effluent Study Final Project

Report, WHC-EP-0367; Hanford Site Stream Specific Reports, WHC-EP-0342; Liquid Effluent Study: Groundwater Characterization Data, WHC-EP-0366. 


\section{A.14 - CONTAMINATION CONTROL IMPROVEMENT PROJECT}

The purpose of the Contamination Control Improvement Project is to encourage the reduction of radioactive surface contamination in operating areas and the environment of the Hanford Site. Reducing the number of contaminated areas and the severity of contamination will reduce the risk of skin contaminations and internal depositions, minimize personnel exposure, increase site productivity, and improve protection of the environment.

The project identifies and encourages the reduction of radioactive surface contamination. It addresses surface contamination areas in three basic areas: (1) indoors, (2) outdoor operating areas, and (3) inactive outdoor areas. It tracks surface contamination. Over time, indoor surface contamination areas are decreasing. Outdoor surface contamination areas are increasing, because winds and the continuing discovery of old waste sites.

The numbers below describe areas posted permanently as "surface contamination areas." For other posted areas see Section D.8.

\section{Indoors}

The Contamination Control Improvement Project ended in 1989 with the identification of approximately $1,720,000 \mathrm{ft}^{2}$ of posted indoor surface contamination areas. By the end of 1990 , there had been a net reduction of $48,000 \mathrm{ft}^{2}$ of indoor surface contamination areas. By the end of March, the posted active indoor surface contamination areas decreased slightly more. As of May, $1,650,000 \mathrm{ft}^{2}$ are posted as indoor surface contamination areas.

\section{Outdoor Operating Areas}

The Contamination Control Improvement Project ended in 1989 with 597 acres posted as outdoor operating surface contamination areas. By the end of 1990 , there had been a net reduction of 3 acres $\left(123,000 \mathrm{ft}^{2}\right)$. In May 1991, the project reported an additional reduction of more than 4 acres $\left(180,000 \mathrm{ft}^{2}\right)$ in posted outdoor operating surface contamination areas. As of May, 590 acres are posted as outdoor operating surface contamination areas.

\section{Outdoor Inactive Areas}

The Contamination Control Improvement Project ended in 1989 with the identification of 296 acres posted as outdoor inactive surface contamination areas. In 1990, there was a net gain of 83 acres $\left(3,600.000 \mathrm{ft}^{2}\right)$ of outdoor inactive surface contamination areas. Most of this resulted from the discovery and posting of the 300-FF-2 operable unit surface contamination areas. By the end of March, the posted outdoor inactive surface contamination areas had increased to a total of approximately 383 acres. In May 1991, there 
was reported a reduction of $13,000 \mathrm{ft}^{2}$ in outdoor inactive surface contamination areas. As of May, 383 acres are posted as outdoor inactive surface contamination areas

Work is ongoing in the plants and areas. 


\section{A.15 - WEAPONS COMPLEX RECONFIGURATION - HANFORD SITE PROPOSAL}

At the direction of DOE-RL, Westinghouse Hanford prepared the Hanford Site Information package describing the option of locating the reconfigured nuclear weapons complex at the Hanford Site." The Hanford Site was one of five DOE sites preparing such information at the direction of DOE-HQ. This package was submitted to DOE-HQ by DOE-RL on June $3,1991$.

This effort is a continuation of the process that began with the development of the Nuclear Weapons Complex Reconfiguration study. The study was delivered to Congress on February 7, 1991. It presents a reassessment of the current problems facing the nuclear weapons complex, outlines expectations for the complex in the 21st century, and charts a proposed course for achieving "Complex 21." Key points are that Complex 21 will be smaller, less diverse, and less expensive to operate in keeping with the current state of improved relations in the world. It will also comply with all applicable Federal, State, and local laws, regulations, and orders.

The development of Complex 21 (wherever it is located) would not divert funding from the DOE's cleanup efforts. These are two activities that are completely separate budget categories that receive funding in the congressional budgeting process.

The location of Complex 21 (or part of $i t$ ) at the Hanford Site would not interfere with the site's cleanup efforts. The proposed location for the Nuclear Weapons Complex Reconfiguration site is previously unused land. It is separated from presently planned cleanup activities. Site infrastructure costs, such as security, roads, etc., now funded mostly by the cleanup budget, could be shared.

The next step in the process is to prepare a programmatic EIS for the nuclear weapons complex (see Section B.12.1). It is anticipated that Westinghouse Hanford will be asked to continue to support the development of information for the programmatic EIS.

*Hanford Site Information Package for the Nuclear Weapons Complex Reconfiguration Site, DOE-0201, U.S. Department of Energy, Richland, Washington, 1989. 


\section{A.16 - RESOURCE CONSERVATION AND RECOVERY ACT REAUTHORIZATION}

Efforts to reauthurize the bill began in 1988 , but the Clean Air Act dominated the environmental agenda in Congress. Now that the Clean Air Act amendments have been passed, Congress is expected to focus on RCRA reauthorization.

The bill's number is S. 976. While subcommittee chairmen are determined and optimistic about reauthorizing RCRA in this session of Congress, it will likely take a few years before the job is done. Listed below are some of the issues Congress will consider as it reauthorizes RCRA:

- Interstate shipment of wastes

- What constitutes "recycling"

- For municipal solid wastes:

- Source reduction and recycling

- Solid waste planning

- Municipal incineration

- Wastes that have been exempted, such as municipal incinerator wastes, medical wastes, and agricultural wastes

- Exclusion of domestic sewage

- Land disposal restrictions

- Closer scrutiny of Federal facilities.

The Administration is not expected to introduce its own RCRA biil. The EPA, however, is trying to promote Administration, positions on key issues. The DOE-HQ is in the process of developing issue papers on RCRA

Reauthorization. Initial input from field offices has been obtained and final drafts of these papers should be available to the field sometime this summer. The issue papers will be used to brief and educate Congressional members and their staff on DOE's problems with RCRA compliance that could be alleviated through reauthorization.

Specific issue paper topics include:

- Development of special management for radioactive mixed waste

- Providing independent technical assistance on radioactive mixed waste to EPA

- Criteria to set priorities for cleanups conducted under RCRA

- Promotion of innovative waste management and remediation technologies 
- Consistency between RCRA and CERCLA cleanup requirements

- Assurance that reasonable resource levels exist for States to administer the RCRA program

- Promotion of recycling, pollution prevention, and minimizations of hazardous waste

- Assurance of the availability of interstate hazardous waste transport

- A ruling for listed waste to set minimum concentration levels before a requirement is triggered. 


\section{A.17 - EMPLOYEES CONCERNS PROGRAM}

The preferred means of resolving issues is for employees to work with their management. This provides managers the opportunity to fix problems they may not have known about, reminds them to communicate with employees on issues being addressed, enables them to prevent or mitigate the effects of recurrence by sharing the information with others, and builds teamwork.

This policy is clearly stated in the Westinghouse Hanford's Open Door Policy: "Employees are strongly encouraged to first discuss problems with the immediate manager. However, when the employee believes it inappropriate to do so, the employee may elect to use this Open Door policy to contact a higher level of management within their division/department, or any other resource within the company, including the President. All managers shall support and assist in arranging such contacts."

The other ways Westinghouse Hanford and BCS-Richland employees may raise concerns include:

- 3-CARE, a hot-1 ine to the safety department

- Employee Appeal Board, for certain personnel issues

- Human Resources, for general employment issues

- Equar Employment Opportunity Office

- Employee Assistance Program, for personal problems

- Grievance Process, for bargaining unit employees

- Employee Concerns Program.

Westinghouse Hanford established the formal Employee Concerns Program in April 1988 to ensure that issues relating to safety, security, quality, environmental protection, and working conditions receive appropriate attention and that employees can raise these issues without fear of recrimination or reprisal. The scope of the program is designed for use by any employee who believes, for any reason, that resolution of a concern by routine interaction with management or a service or oversight organization is inappropriate or may be ineffective.

An employee who decides to use the Employee Concerns Program can file a concern anonymously or in confidence. Whether or not an employee asks for confidentiality, the identity of the employee who files a concern is treated with a high degree of sensitivity.

The philosophy is that it should be very easy for an employee to file an employee concern. The employee can write the concern or verbalize it in person or on the phone. The employee can address the concern to any Westinghouse Hanford/BCS-Richland manager, including the President; the 
Employee Concerns Program manager; or any Employee Concern Program coordinator. Names of program representatives are posted conspicuously throughout the site as well as on the electronic mail system.

When the Employee Concern Program office is notified of the concern by the receiver, it assigns a tracking number, a coordinator, and an action assignee. The coordinator must ensure that the concern is resolved in a timely manner and report the resolution back to the employee. The action assignee will perform the actions needed to resolve the concern, or investigate the concern and make recommendations to management for action. Resolutions vary in complexity from a simple explanation of a procedure, or a team investigation of a concern and development of long-range commitments. If an employee is dissatisfied with efforts to resolve the concern, the employee has the right at any time to elevate a concern to a higher level or different chain of management, up to and including the President of Westinghouse Hanford or the DOE.

The program has been widely used since its inception. Between April 1, 1988 and Apri1 1, 1991, 1,428 concerns were started.

\section{Types of Concerns}

$42 \%$ Safety, quality, environmental protection or ethics issues

$58 \%$ Policy, pay, benefits, appraisals, and other related issues.

\section{Resolution of Concerns}

$53 \%$ of all concerns were resolved with management generally agreeing with the concern and taking action to change or enforce policy or direction or by making improvements in the work place.

$39 \%$ of all concerns were resolved by explanation of policy or providing needed information. 


\section{A. 18 - HANFORD INTEGRATED PLANNING PROCESS}

The Hanford Integrated Planning Process will provide top-level, technical program planning for all current and future Hanford activities in Environmental Restoration and Waste Management. Historically, the Hanford Site has been managed by multiple programs with separate objectives and few defined interactions between them. Now, since the mission of programs is essentially identical (site cleanup), interactions among programs have become the rule rather than the exception. However, since the programs have been directed separately, inconsistencies in approach and lack of overall coordination have become apparent. This integrated planning activity will enhance both interprogram and intercontractor coordination. It will facilitate progress, efficiency, and public acceptance by both performers and other stakeholders.

The overall process starts with direction from DOE-HQ plannirg documentation. The process will develop a hierarchy of plans starting with a Hanford Strategic Plan setting out the site mission, the long-term vision, and the values guiding the site in the conduct of Hanford cleanup activities.

The Strategic Plan will help guide the development of the Mission Plan. The Mission Plan will define the technical pathways to desired results of cleanup activities. The Mission Plan will define the decision pathways for the development and implementation of the desired results. Finally, it will identify top-level goals and objectives to drive the development of Multi-Year Program Plans. The technical pathways, once defined, should be durable and exhibit stability without changing from year to year, even though the rate of progress may change depending on resource allocations.

The Tri-Party Agreement will guide the planning efforts. The Multi-Year Program plans and the Fiscal Year Work plans, derived from the Multi-Year Program plans, will set forth the specific schedules, work scopes, and define the budgets for the cleanup activities. They will form the basis for the allocation of resources to complete the activities called for by the technical plans.

In addition to the technical program plans, the activity will define a public interaction process to develop an integrated approach to secure input from and to build consensus among stakeholders as to the desired end states and technical pathways. Another important function is the dissemination of information about the overall long-term plans for the disposition of Hanford wastes.

The results of this process will include:

- An Integrated Technical Plan

- Consensus on appropriate pathways for material disposition

- Better definition of required workscope 
- Consistent funding

- Concerted action to clean up the site, consistent from area to area.

This Integrated Planning Activity is a joint DOE-RL and multi-contractor activity. Lead responsibility is assigned to Westinghouse Hanford with PNL playing a major role. However, informal and formal interactions with Kaiser Engineers Hanford and the Hanford Environmental Health Foundation are an important aspect of the process.

Although the full planning process will not be completely implemented until FY 1994, initial draft versions of the Site Strategic Plan and the Mission Plan are due the first of August. The final version of the initial plans are to be complete by September 30, 1991. 


\section{A.19 - HORN RAPIDS CONTAMINATION}

Eight groundwater monitoring wells were drilled and sampled in the vicinity of the Hanford Site's Horn Rapids Landfill, north of Horn Rapids Road and west of Stevens Drive, as part of the Phase I remedial investigation of the 1100-EM-1 operable unit under Superfund. Wells northeast and east of the landfill have been found to be contaminated with several chemicals at levels above primary or secondary drinking water standards through five quarterly rounds of sampling. In particular, levels of trichloroethene, nitrate, and gross beta have been found which exceed drinking water standards. Additional contamination by 1,1,1-trichloroethane, tetrachloroethene, and sulfate not exceeding drinking water standards has also been found. Levels of contamination and applicable drinking water standards are tabulated below:

\begin{tabular}{|c|c|c|c|}
\hline Contaminant & $\begin{array}{l}\text { Concentration } \\
\text { detected (ppb }\end{array}$ & $\begin{array}{l}\text { Drinking water } \\
\text { stanterd (ppb) }\end{array}$ & $\begin{array}{l}\text { Area } \\
\text { background (ppb) }\end{array}$ \\
\hline Trichloroethene & $40-110$ & 5 & 0 \\
\hline $1,1,1$-Trich1oroethane & $0-1$ & 200 & 0 \\
\hline Tetrachloroethene & $0-4$ & - & 0 \\
\hline Nitrate & $140,000-270,000$ & 45,000 & $10,000-35,000$ \\
\hline Sulfate & $60,000-90,000$ & 250,000 & $10,000-40,000$ \\
\hline Gross beta & $50-90 \mathrm{pCi} / \mathrm{L}$ & $50 \mathrm{pCi} / \mathrm{L}$ & $1-30 \mathrm{pCi} / \mathrm{L}$ \\
\hline
\end{tabular}

"Parts per billion.

Subsequent investigation has determined that wells on Advanced Nuclear Fuels Corporation's property are also contaminated with all of these constituents.

The EPA and DOE determined that contaminated groundwater beneath the Hanford Site was the responsibility of DOE based upon Superfund Sections 113 and 120 and Executive Order 12580. DOE has subsequently enjoined Advanced Nuclear Fuels Corporation to participate in the remedial investigation of the groundwater in the vicinity of the Horn Rapids Landfill since the contamination source has not yet been identified. A cooperative DOE/Advanced Nuclear Fuels monitoring program has been requested.

Phase II remedial investigation soil gas surveys indicate a plume of contaminated groundwater extending between the effluent treatment lagoons, of Advanced Nuclear Fuels and Stevens Drive. Six additional confirmatory groundwater monitoring wells are being drilled to define the extent of the plume before aquifer pump tests are planned to determine the rate of groundwater flow in the area. 


\section{A.20 - GENERAL ACCOUNTING OFFICE INVESTIGATION OF SOIL AND GROUNDWATER MONITORING}

The General Accounting Office started an investigation of soil (vadose zone) and groundwater monitoring activities at Hanford during the last quarter. The review is expected to continue through FY 1991. The scope of the investigation, requested by Senator John Glenn, presently involves only a general review of the subject areas. Based on the kick-off meeting and subsequent inquiries, the review includes the following:

- Structure and function of DOE/contractor interfaces

- Implementation plans

- Work plans

- Sampling and analysis procedures

- Quality assurance

- Database systems

- Reporting procedures.

The General Accounting office is also reviewing related Tiger Team findings, followup on the 1987 DOE-HQ "Mary Walker" Environmental Survey and other audit findings, and is apparently using them as a baseline or reference point against which to assess progress. After presentation of preliminary findings to the Glenn committee, the scope will be narrowed, redirected, or terminated depending on the committee's reaction.

In addition to responses to requests for information and documents, Westinghouse Hanford Geosciences staff arranged a field tour of groundwater sampling activities and a demonstration of spectral gamma logging equipment for two auditors from the Seattle office. The audit team was especially interested in the status of previous General Accounting Office recommendations concerning the need for improved spectral gamma logging equipment and procedures.

Another area of particular interest is the relationship between the Hanford Site groundwater protection management program and implementation of the ongoing groundwater monitoring activities conducted for superfund (CERCLA), RCRA, Operational Monitoring and the Site-Wide Surveillance programs (PNL), and the status of the office of well management and groundwater protection covered in the Groundwater Protection Management program. 
WHC - SP - $0434-11$

$06 / 28 / 91$

This page intentionally left blank. 


\section{B.1 FY 1993 ENVIRONMENTAL MANAGEMENT FIELD BUDGET REQUEST}

Westinghouse Hanford submitted the FY 1993 Environmental Management Field Budget Request for Hanford to DOE-RL on June 13, 1991.

The request includes the funding needed to support recent Tri-Party Agreement negotiations and waste tank safety issue resolution. The Hanford Waste Vitrification Plant budget revisions include $\$ 58.2$ million in FY 1992 and $\$ 98.9$ million in FY 1993 to support the December 1999 hot startup commitment. The requested EM funding is as follows:

- FY 1992 minimum required of $\$ 1184.9$ million

- FY 1993 required of $\$ 1544.0$ million.

These requirements reflect increases of $\$ 78.1$ million in FY 1992 and $\$ 43.2$ million for FY 1993 over Case 1 Prime due to recent Tri-Party Agreement negotiations. Increased funding of $\$ 70.8 \mathrm{mill}$ ion is also included in the FY 1992 minimum required to accelerate resolution of hydrogen and ferrocyanide issues in the waste tanks, and perform tank farm upgrades.

Table B-1 shows minimum funding requirements, including the funding needed to support the May 1991 renegotiation of several major and interim Tri-Party Agreement milestones. Milestone commitments in this budget request are dependent upon receiving FY 1992 minimum required and FY 1993 required levels. 
Table B-1. FY 1993 Field Budget Request Summary of Estimates (Environmental Management).

\begin{tabular}{|c|c|c|c|c|}
\hline Category & $\begin{array}{l}\text { FY } 1991 \\
\text { Approp }\end{array}$ & $\begin{array}{l}\text { FY } 1992 \\
\text { Pres Bud }\end{array}$ & $\begin{array}{l}\text { Fy } 1992 \\
\text { Minimum } \\
\operatorname{Req}^{\prime} d^{c}\end{array}$ & $\begin{array}{l}\text { Fy } 1993 \\
\text { Req }^{\prime} d^{d}\end{array}$ \\
\hline \multicolumn{5}{|c|}{$\begin{array}{l}\text { Summary of Estimates - All Funding } \\
\text { (In thousands of dollars) }\end{array}$} \\
\hline $\begin{array}{l}\text { Corrective Activities } \\
\text { Defense (EW-1C) } \\
\text { Non-Defense (EX-10) }\end{array}$ & $\begin{array}{r}22398 \\
397\end{array}$ & $\begin{array}{r}10932 \\
3045\end{array}$ & $\begin{array}{r}10932 \\
3045\end{array}$ & $\begin{array}{r}2405 \\
50\end{array}$ \\
\hline Subtotal & 22795 & 13977 & 13977 & 2455 \\
\hline $\begin{array}{l}\text { Waste Management } \\
\text { Defense (EW-30)(EW-70) } \\
\text { Non-Defense (EX-30) }\end{array}$ & $\begin{array}{r}533589 \\
86929 \\
\end{array}$ & $\begin{array}{r}859770 \\
7385 \\
\end{array}$ & $\begin{array}{r}999962 \\
7385 \\
\end{array}$ & $\begin{array}{r}1285530 \\
18738\end{array}$ \\
\hline Subtotal & $620518^{b}$ & 867155 & 1007347 & 1304268 \\
\hline $\begin{array}{c}\text { Environmental Restoration } \\
\text { Defense (EW-20) } \\
\text { Non-Defense (EX-20) }\end{array}$ & $\begin{array}{r}130851 \\
0\end{array}$ & $\begin{array}{r}148000 \\
6900\end{array}$ & $\begin{array}{r}156700 \\
6900\end{array}$ & $\begin{array}{r}236208 \\
1082\end{array}$ \\
\hline Subtotal & 130851 & 154900 & 163600 & 237290 \\
\hline Total & $774164^{b}$ & 1036032 & 1184924 & i544013 \\
\hline
\end{tabular}

${ }^{2}$ Does not include reprogramming or supplemental budgets (except for Hanford Waste Vitrification Plant: $\$ 58.2 M$ in 1992 and $\$ 98.9 M$ in 1993).

Includes $\$ 14.6 \mathrm{M}$ carryover.

'Required to support May 1991 Tri-Party Agreement negotiations and waste tank safety issues ( $\$ 70.8 \mathrm{M}$ increment over President's Budget).

${ }^{d}$ Includes incremental funding needed to support Tri-Party negotiations. 


\section{B.2 - FIVE-YEAR PLAN}

As it relates to the Hanford Site, the 'Five-Year Plan' consists of the DOE-HQ plan entitled Environmental Restoration and Waste Management Five-Year Plan for FY 1992 through 1996, and the Hanford site-specific plan.

\section{B.2.1 THE DOE-HQ FIVE-YEAR PLAN}

The DOE-HQ Five-Year Plan, updated to cover FY 1990 through 1996 (with emphasis on the latter 5 years), was issued in July 1990. The plan is currently being updated to cover FY 1991 through FY 1997. It should be released in July. It is issued annually. The plan covers nine DOE sites, including the Hanford Site, that conduct environmental restoration, waste management operations, technology development, transportation, and corrective activities. The document stresses cultural changes (changes in the way DOE does business) as well as the technical activities needed for compliance and cleanup. The DOE-HQ Five-Year Plan is the cornerstone of and the framework for DOE's long-term strategy in environmental restoration and waste management.

\section{B.2.2 HANFORD SITE-SPECIFIC PLAN}

Four major parts make up the Hanford site-specific plan. These are the overview document, the vision statement, the detailed information document, and the activity data sheets (ADS) document. All went out for public review from April 20 to July 19, 1990 (90 days). They are described below.

The first document is called Overview of the Hanford Cleanup Five-Year Plan. It summarizes the detailed document described below and provides additional information of a more general interest, such as cultural change within the DOE, a historical account of the extent of the Hanford Site's environmental problems, and nontechnical descriptions of the Hanford Site's wastes.

The vision statement, Five-Year Vision for Hanford Cleanup, is a fourpage publication that is generally distributed with the overview document. It presents the DOE vision of the progress it should achieve in the next 5 years to meet the 30-year goal of cleaning up inactive facilities and waste sites. The status of individual goals in the vision statement, cultural as well as technical, will be included in future updates of the detailed information document.

The detailed information document, approved by DOE-HQ in March 1990, is Environmental Restoration and Waste Management Site-Specific Plan for the Richland Operations Office: Detailed Information, DOE/RL 89-10. This document provides planning information for environmental restoration, waste managenent operations, and corrective activities at the Hanford Site for FY 1989 to 1995. It is the Hanford Site implementing document for the DOE-HQ Five-Year Plan for waste management and environmental restoration. An update was drafted and sent to DOE-HQ on October 31, 1990. This update will not be 
publicly issued except for the public comment and response section. This is because of DOE-HQ changes in plans and because other DOE sites did not have corresponding updates.

Another update is in progress. We expect to issue it about August 1 for a two-month public comment period. It will include activities through FY 1997 based on the latest ADSs. This will coincide with the issuance of the DOE-HQ Five-Year Plan expected in June.

The fourth part of the Hanford plan consists of ADSs. This document, The Hanford Site Environmental Restoration and Waste Management Five-Year Plan Activity Data Sheets, DOE/RL 89-17 Rev. 1, contains a collection of individual data sheets for each activity. An update of the data sheets should be issued soon. The sheets consist of narrative, priorities, funding profiles, alternatives, and milestones for Hanford Site environmental restoration, waste management, and corrective activities. These ADSs form the bas is of the planning contained in the overview and detailed information documents, as well as the Hanford Site data in the national plan.

Key changes from last year are the inclusion of Tiger Team findings, inclusion of all Defense Programs scope beginning in FY 1992, addition of waste tank safety and upgrades, and updated cost estimates for accomplishing the work. 


\section{B.3 - EFFLUENT RELEASE PERMITS}

\section{B.3.1 NATIONAL POLLUTANT DISCHARGE ELIMINATION SYSTEM PERMIT}

The Clean Water Act requires a National Pollutant Discharge Elimination System permit for discharges to rivers. One permit, No. WA-000374-3, governs Hanford's discharges to the Columbia River. The permit was issued December 7 , 1981, expired December 31,1985 , and presently is being renegotiated. Until a new one is issued, conditions of the current permit remain in effect.

The National Pollutant Discharge Elimination System permit specifies discharge points (of which there are eight), effluent limitations, and monitoring requirements. Above-limit conditions are detected by a routine sampling and analysis program for each of the eight discharges. Sample requirements include temperature, flow, $\mathrm{pH}$, free available chlorine, total suspended solids, oil and grease, iron, ammonia, and chromium. Sampling activities for each outfall are summarized and reported to EPA monthly.

The eight separate discharges included in the Hanford Site National Pollutant Discharge Elimination System permit are as follows:

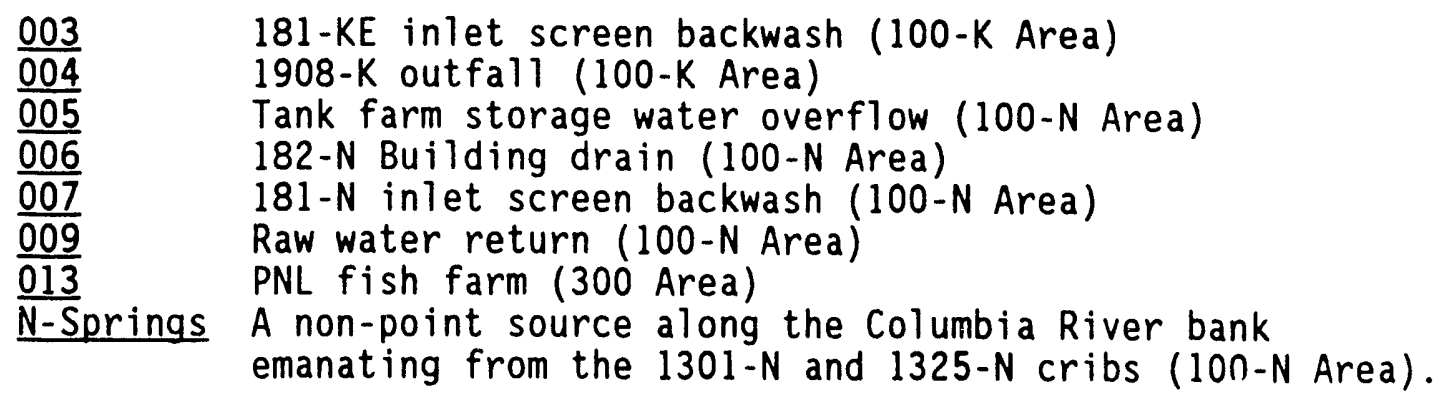

Outfalls 005, 006, 007, and 009 have considerably reduced discharges since $\mathrm{N}$ Reactor is in dry layup.

\section{B.3.2 PREVENTION OF SIGNIFICANT DETERIORATION PERMIT}

Nitrogen oxide emissions from the Hanford Site are permitted under the Prevention of Significant Deterioration (PSD) regulations stemming from the Clean Air Act. Emissions from the PUREX and $\mathrm{UO}_{3} \mathrm{Plants}$ are controlled to specific limits listed in the PSD permit. Emissions from the coal-and oilfired steam plants were grandfathered in the PSD permit upon its issuance in 1980. There have been no PSD permit violations since August 1988.

Since 1987, EPA delegated to Ecology the authority to enforce the PSD program. As one condition for such delegation, Ecology enforces State PSD regulations that are at least as stringent as those of EPA. Any changes to the Hanford Site PSD permit will be processed by Ecology. 
The PSD program regulates pollutants that degrade the environment. The EPA regulates hazardous air pollutants, including radionuclides, under separate standards. (Those are called the National Emission Standards for Hazardous Air Pollutants.)

The Clean Air Act Amendments of 1990 call for removal of a quirk in the law that resulted in Hanford radioactive air emissions being regulated under two permit programs. Such dual regulation has increased costs of permitting without increasing protection of the public.

Though the amendments became law in November of 1990, the PSD implementing regulations have not been changed. On March 11, 1991, EPA Headquarters did issue a memo which called for an immediate halt to the dual regulation. The DOE-RL sent a letter to Ecology calling for removal of the dual permitting burden. A further letter has been drafted that indicates DOE-RL intentions to discontinue observance of the dual regulation unless Ecology responds with a description of why such practice must continue.

\section{B.3.3 REGISTRATION OF RADIOACTIVE AIR EMISSION STACKS}

The Washington State Department of Health, Division of Radiation Protection, has promulgated regulatory controls for radioactive air emissions under allowance provided in Section 116 of the Clean Air Act. The Washington Administrative Code (WAC) 402-80 requires registration with the Department of Health of all radioactive air emission point sources. All Hanford radioactive stacks providing significant emissions are registered with the Department of Health. On August 15, 1989, the Department of Health issued its first Radioactive Source Registration permit, No. FF-01, to the DOE-RL. The permit is issued for a 2-jear period of 1 imited radioactive air emissions from Hanford Site operations.

A total of 130 stacks are registered with the Department of Health and are operated under the permit. Washington State law requires us to give the Department of Health an annual report of emissions from each stack and the resulting offsic dose impact.

Each stack having potential to emit significant airborne radioactivity is monitored to ensure compliance with effluent limitations. Near-field and offsite air sampling stations also are operated to detect any trends toward elevated radioactive releases from stacks as well as from diffuse sources. Immediate reporting is required of any change in facility operations that could result in airborne radionuclide emissions providing additional offsite dose impact. 


\section{B.4 - RESOURCE CONSERVATION AND RECOVERY ACT}

\section{B.4.1 - RCRA INTERIM STATUS}

Westinghouse Hanford has identified 63 treatment, storage, and disposal (TSD) units that must be permitted or closed in accordance with RCRA and Washington State Dangerous Waste Regulations, WAC 173-303. Some of the units have numerous individual components. The single-shell tank TSD unit includes 149 separate tanks. About one half of the TSD units will be closed under RCRA interim status. For the remaining units we will apply for RCRA Part B operating permits. The RCRA permitting and closure plans are discussed in Section B.4.2.

Dangerous waste interim status facilities are summarized as follows:

- 63 TSD facilities under RCRA interim status

- 48 facilities assessed for RCRA interim status compliance

- 35 facilities to be closed under RCRA interim status

- 10 facilities under construction or petitioning for permit withdrawal.

We have assessed 48 TSD facilities to ensure we are meeting RCRA interim status requirements. Where compliance issues were identified, we have taken or set a date for corrective actions consistent with Milestone M-22-00, "Establish Enforceable Corrective Action Schedules," of the Tri-Party Agreement. Schedules for interim status corrective actions now appear as Milestone M-23-00. One exception is that we are still negotiating corrective actions for dangerous waste tank technical requirements.

Only two corrective actions remain. They are to submit the T Plant treatment-by-generator request and to reissue the $B$ Plant contingency plan.

The majority of deficiencies that were corrected were administrative. Several facilities do not meet minimum technological requirements and, therefore, are undergoing closure. Additional corrective action ichedules are being negotiated. Existing tank systems will require substantial upgrades. Discussions of corrective action schedules and negotiation of a new Tri-Party Agreement milestone for interim status tank system technical requirements are under way.

We plan to complete all identified potential RCRA interim status actions by September 1991. The exception to this are closure plans, groundwater monitoring well installations, and negotiated major plant upgrades. 


\section{B.4.2 - RCRA PERMITTING AND CLOSURES}

Ecologv and EPA have assigned the Hanford Site a single dangerous waste penit identification number. This number (WA-78-90008-967) encompasses all TSD waste managenient units at Hanford. These 63 TSD units are co-operated by DOE-RL and two of its contractors (56 by Westinghouse Hanford and 7 by PNL). About half of these units will be closed; the remaining T'SD units will be permitted for operation.

The Tri-Party Agreement outlines the plans, approach, and schedule for meeting RCRA requirements for TSD waste management units at the Hanford Site. Part Two of the agreement has provisions governing TSD hazardous waste facility permitting, closure, and post-closure activities. The Tri-Party Agreement Action Plan delineates the actions to be taken and establishes the overall plan to conduct RCRA permitting and closures.

Because all TSD waste management units will not meet RCRA permitting requirements at the same time, they cannot be permitted simultaneously. Therefore, Ecology and the EPA will issue the initial permit for less than the entire facility. Each TSD operating unit will be added as a major modification to the permit as documentation is completed in accordance with the Action Plan schedule. Each operating TSD unit included in the permit will subsequently be required to operate under the provisions of the permit rather than interim status standards. This permit will eventually grow into a single permit for the entire Hanford Site. The initial permit for the Hanford Site is yet to be issued, but is anticipated in the spring of 1992 .

The RCRA permitting and closures status is shown on Table B-2. 
Table B-2. Dangerous Waste Regulations Permitting Status. (sheet 1 of 3 )

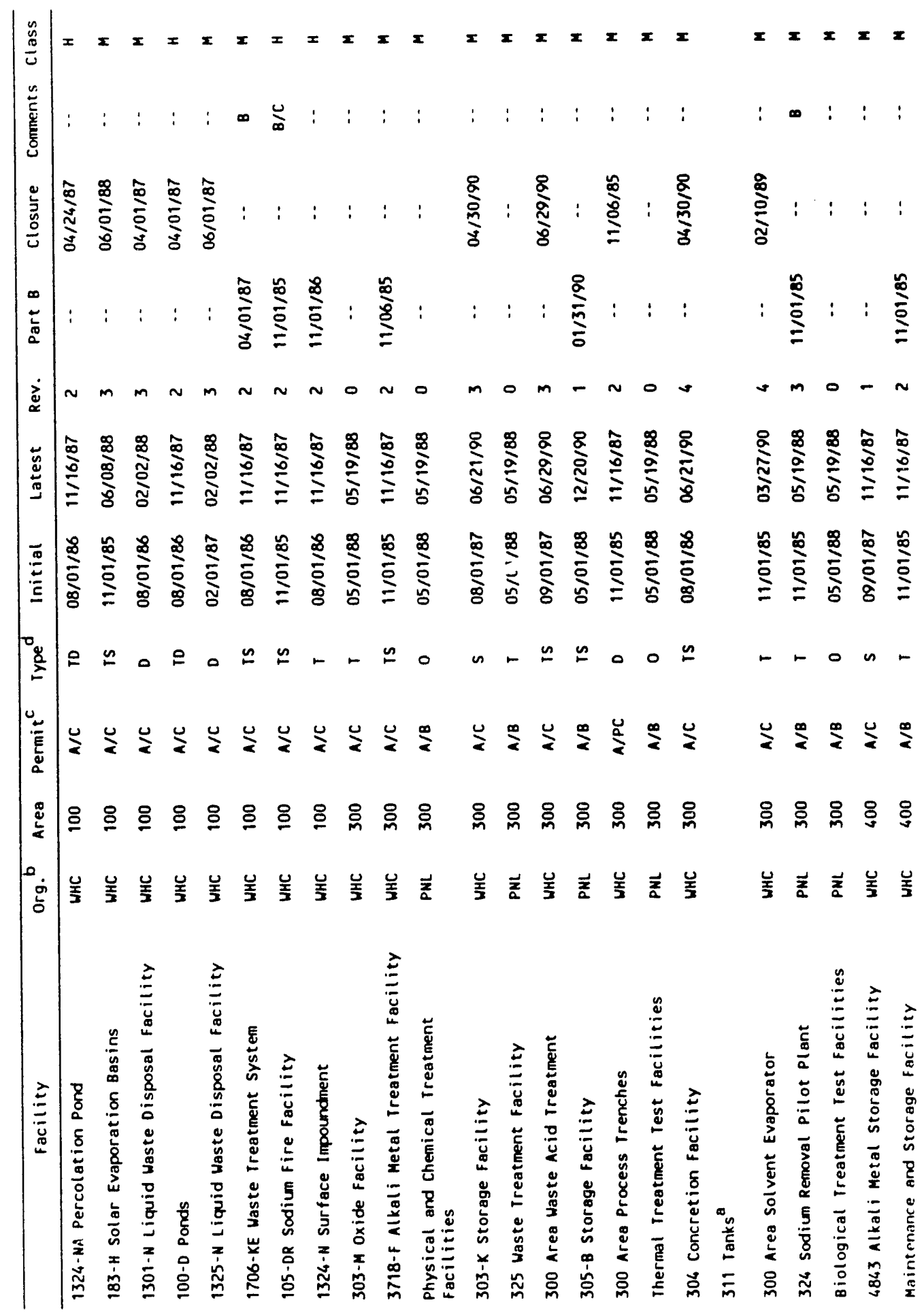


Table B-2. Dangerous Waste Regulations Permitting Status. (sheet 2 of 3 )

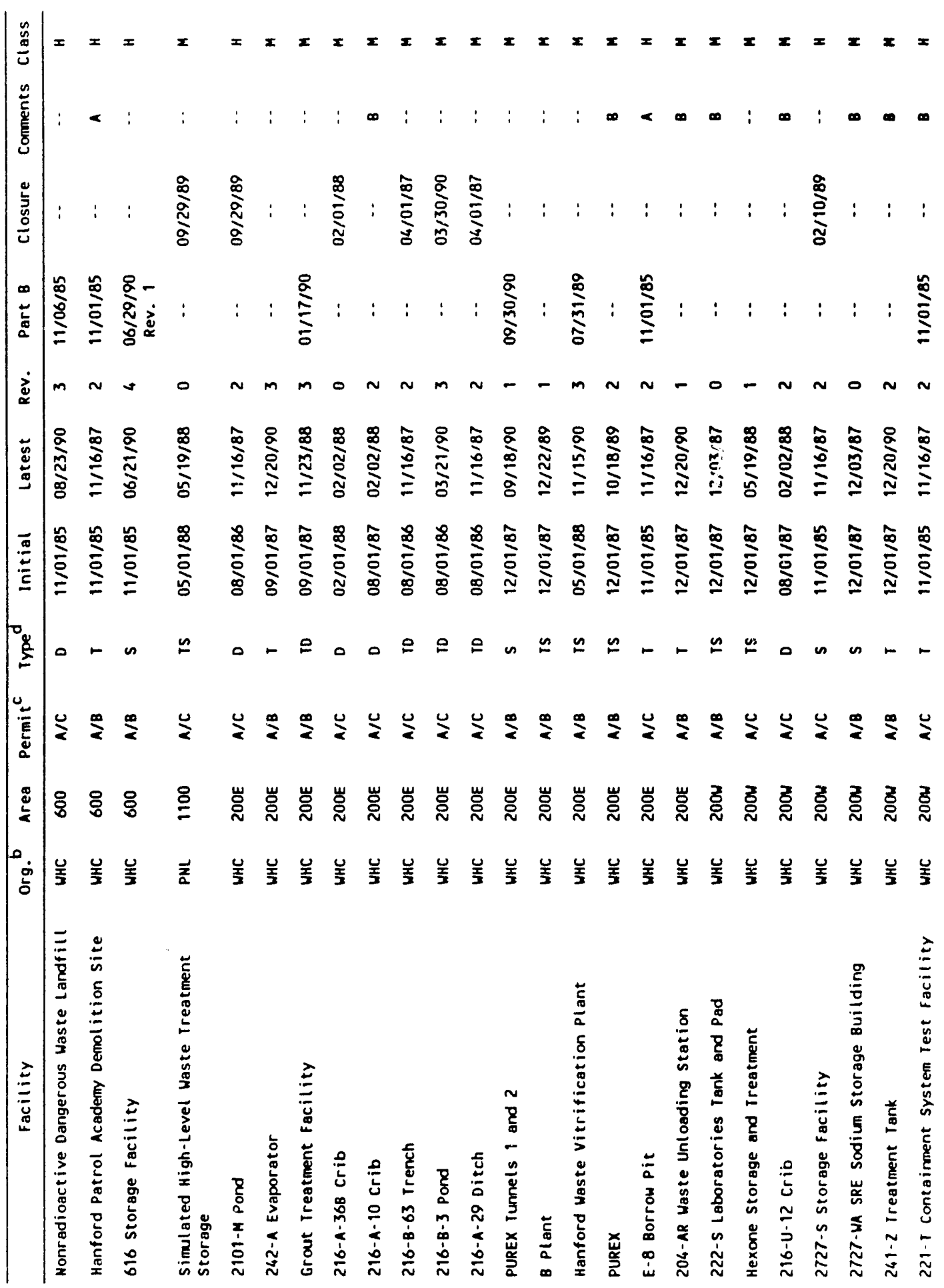


Table B-2. Dangerous Waste Regulations Permitting Status. (sheet 3 of 3 )

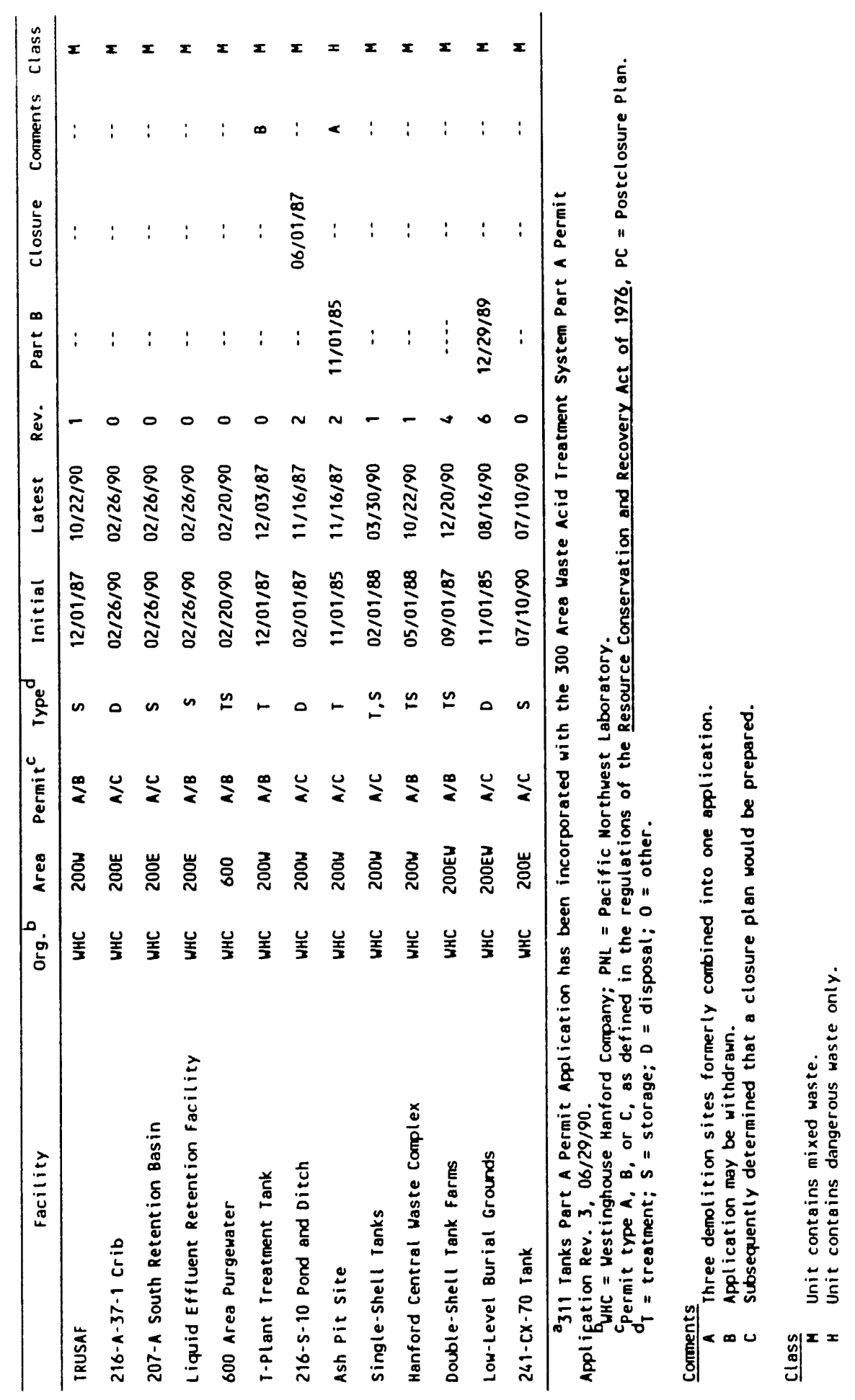




\section{B.5 - SUPERFUND}

\section{B.5.1 SUPERFUND REQUIREMENTS}

In 1980, Congress passed the Superfund (also called CERCLA) to address cleanup of inactive hazardous waste sites. In 1986, Congress amended it to extend cleanup procedures and requirements to include Federal facilities. This is entitled the Superfund Amendments and Reauthorization Act of 1986. The Tri-Party Agreement governs the implementation of the these regulations and the State Superfund at the Hanford Site.

To comply with the Superfund regulations, a potentially responsible party must follow a structured process to assess its site and determine appropriate remediation. The process includes preliminary assessment and site investigation, site characterization and alternative evaluation, documenting remedial action decided upon, and implementing the remedial action decision. Public involvement is required throughout the Superfund process.

\section{National Priorities List}

The National Priorities List (NPL) is an ordered ranking of Superfund sites. These sites were evaluated using a hazard ranking system and placed on the NPL in order of decreasing potential hazard. This hazard ranking system score establishes the priority in which the sites will be funded by the EPA and remediated. The responsible Federal agency, not the established Superfund, will fund remediation of Federal NPL sites. Section 120 of the law requires that Federal agencies with sites on the NPL enter into interagency agreements with EPA to clean up those sites.

To place Hanford's inactive sites on the NPL we first ranked the site through the hazard ranking system. Then we grouped them into aggregate areas (Figure B-1). The NPL package proposed to EPA consisted of four aggregate areas $(100,200,300$, and 1100 Areas), which were scored through the hazard ranking system.

A 60-day public comment period in the summer of 1989 yielded only two comment letters on the Hanford Site nomination. On November 3, 1989, EPA added all four of the Hanford Site waste sites to the NPL (Federal Register, Vol. 54, No. 191, p. 41015). Inclusion on the NPL mandates funding and initiation of cleanup of the four sites. 
Figure B-1. Aggregate National Priorities

List Sites for the Hanford Site.

\section{The Hanford Site}

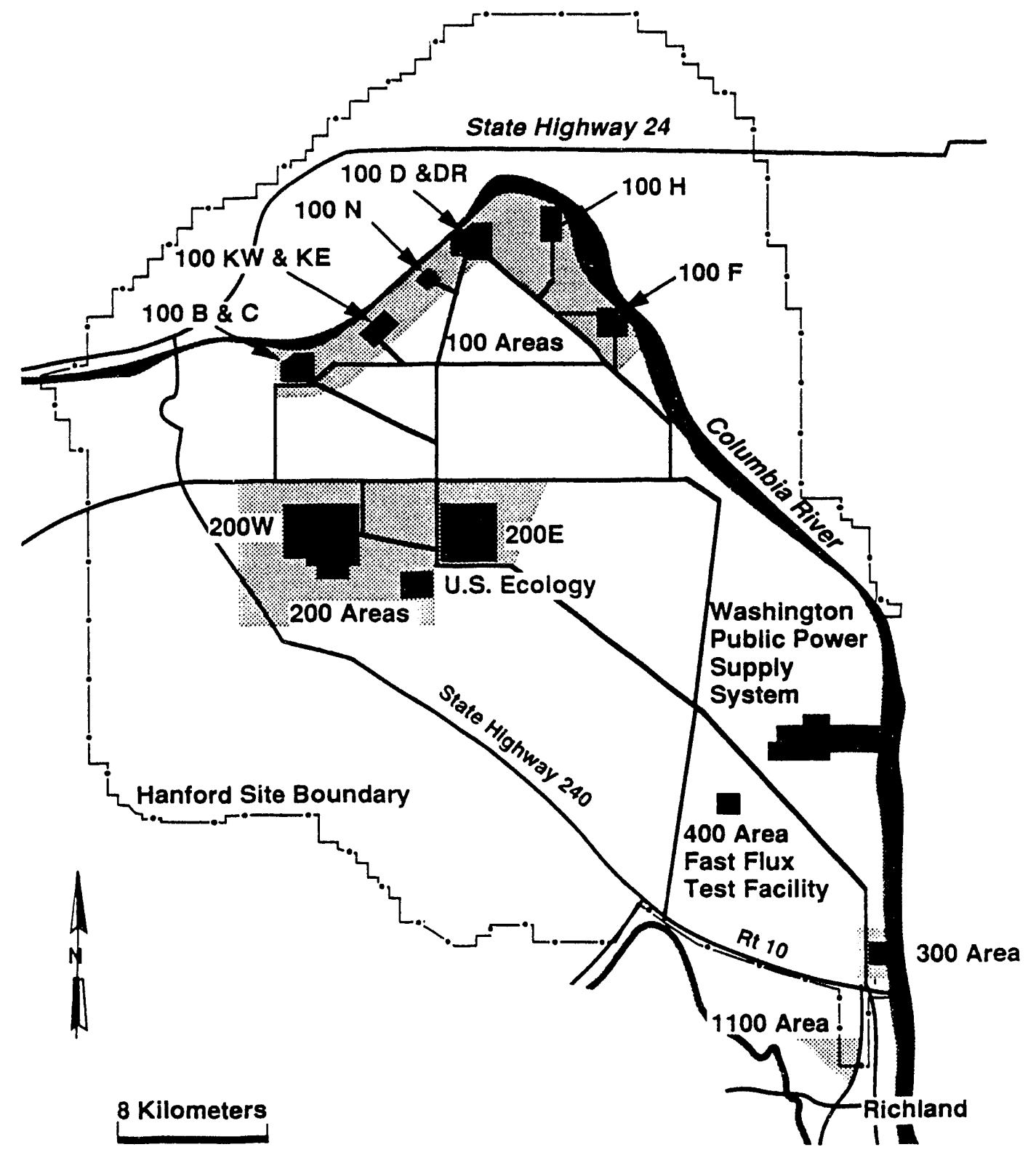

79011048 


\section{B.5.2 INTERIM REMEDIAL ACTIONS}

The radiation area reduction program has stabilized or decontaminated more than 880 acres on the Hanford Site, including stabilization and/or decommissioning of $S$ Pond, $U$ Pond, and Gable Mountain Pond. In addition, about 1,000 acres of inactive waste sites are sprayed annually with selective herbicides. This is to control the growth of vegetation that may penetrate the waste barrier and cause contamination to surface and spread.

The most recent major stabilization effort was completed at Gable Mountain Pond (216-A-25). The pond was commissioned for service in 1957 to receive cooling water from PUREX operations. Facilities eventually served by the pond included PUREX, B P1ant, 242-A Evaporator, 244-AR Vault, 200 East Area Powerhouse, and 241-A Tank Farm. The pond had a wetted area of about 82 acres, and an additional 100 acres surrounding the pond were surface contaminated. The decommissioning of Gable Mountain Pond began in 1984 and was completed in 1988. Filling the pond and placement of soil required about 1 million cubic yards of material. The total cost of the project was $\$ 2.67$ million.

On October 18, 1990, Energy Secretary Watkins proposed three additional accelerated cleanup actions. These actions will be completed as interim response actions, a way to speed up cleanup activities at sites where actions taken now could prevent further spread of contamination. (See Section A.7).

\section{B.5.3 CHARACTERIZATION AND REMEDIATION OF PAST-PRACTICE WASTE UNITS}

The Hanford Site contains 1,502 identified waste management units to be characterized and remediated and/or permitted during the next 28 years. These units include various types of liquid waste disposal sites, solid waste burial grounds, underground tanks, and unplanned release sites. The wastes disposed of in these units include nonhazardous solid, hazardous, radioactive (including low activity, high activity, and TRU), and mixed wastes. To deal with this number of waste units, the Hanford Site was subdivided into four aggregate areas, each of which is included on the EPA NPL.

The four aggregate areas have been divided into 78 operable units. Within the next 28 years, each operable unit will be investigated and remediated under RCRA past-practice and/or Superfund process as defined in the Tri-Party Agreement.

For units addressed under RCRA, the investigation will be documented in a RCRA remedial feasibility investigation/corrective measures study (RFI/CMS); for units addressed under Superfund, the investigation will be documented in an remedial investigation/feasibility study (RI/FS). Although the processes differ somewhat, they are functionally equivalent.

Either EPA or Ecology will serve as the lead agency. The lead regulatory agency concept is to minimize duplication of effort and maximize productivity. The lead agency will oversee actions at specific operable units; the other 
will be the support agency, assisting as needed. The EPA and Ecology will jointly decide which will serve as lead agency for each operable unit.

\section{B.5.4 OPERABLE UNIT STATUS}

In support of the Tri-Party Agreement and the listing of the four Hanford Site aggregate areas on the EPA's NPL, the DOE-RL has initiated the RI/FS or RFI/CMS process. The following paragraphs describe progress to date on these activities.

\section{0-EM-1 Operable Unit}

This operable unit is given a high priority because of the presence of water supply wells about a half-mile east of the vehicle maintenance facility. Groundwater monitoring wells have shown no contamination in the aquifer near the well field. Quarterly monitoring results are reported to the city of Richland.

The 1100-EM-1 operable unit contains seven waste sites associated with vehicle maintenance operations. The unit does not contain radioactive material.

- An abandoned battery acid pit into which an estimated maximum quantity of 15,000 gallons of battery acid was disposed of from 1954 to 1977. A characterization borehole iniough the pit showed that the contamination did not approach levels that would require cleanup actions.

- Two abandoned gravel pits used primarily for disposal of construction debris until 1985. These pits received paints, solvents, and other chemicals from vehicle cleaning operations, but characterization boreholes and groundwater monitoring wells found minimal contamination.

- A waste antifreeze tank, removed in 1986, which was suspected to have leaked. Soil samples from beneath the tank site showed no contamination.

- The site of a minor leak of radioactive water from a shipping cask onto a track. Radiation monitoring at the time of the incident showed that no water reached the ground.

- An area of discolored soil resulting from the surface disposal of a plasticizer. Action is being planned to remove about $2.5 \mathrm{yd}^{3}$ of contaminated soil.

- An abandoned landfill used for disposal of office and construction waste before 1970. Groundwater beneath the 1 andfill and its vicinity has been found to be contaminated with trichloroethene, 
nitrates, and gross beta above drinking water standards, apparently from a source outside the Hanford Site (see Section A.19). No drinking water is affected.

The EPA approved the RI/FS work plan for the 1100-EM-1 operable unit in August 1989. It was the first such work plan to be approved under the TriParty Agreement. The remedial investigation Phase I report was submitted to EPA last August. The feasibility study Phase I and II report was submitted in December to meet the first 1100-EM-1 milestone. By September 1991, work on further RI/FS reports will be transferred to the U.S. Army Corps of Engineers (see Section B.10.5).

\section{0-BP-1 Operable Unit}

The 200-BP-1 operable unit occupies approximately 25 acres within the 200 East Area and includes 13 waste management units (approximately 4 acres). The wastes disposed to the waste management units originated from the U Plant uranium reclamation process and 241-BY Tank Farm operations. The waste management units include 10 inactive cribs and three unplanned releases.

The 200-BP-1 operable unit was ranked third in priority (operable unit working order for environmental restoration remedial action) as a result of a cyanide plume in the groundwater north of the operable unit. The EPA approved the RI/FS work plan for the 200-BP-1 operable unit in March 1990.

Installation of groundwater wells began in April 1990. A total of nine wells have been completed. A groundwater sampling program has begun. Preparation work for source and vadose zone sampling efforts has also begun. One vadose zone borehole has been drilled and sampled to verify that one of the 10 inactive cribs was never used.

\section{0-FF-1/300-FF-5 Operable Units}

The 300-FF-1 source operable unit occupies approximate y 140 acres along the Columbia River in the northeast corner of the 300 Area. The $300-F F-5$ is a groundwater operable unit which underlies and is potentially affected by $300-F F-1$ and two adjacent 300 Area source operable units. The $300-F F-1$ operable unit contains all of the major past and present liquid waste disposal units ill the 300 Area. The $300-F F-1$ waste management units contain residues from process liquid waste staging facilities containing drummed waste $0 i 1$ and small containers of hazardous waste. The EPA approved the RI/FS work plans for the 300-FF-1 and 300-FF-5 operable units in June 1990.

Work was started, and in some cases completed, on the $300-F F-1$ operable unit includes a complete surface radiation survey, a survey of birds, plants, and medium- to large-sized mammals present within the operable unit, sampling and analysis of vegetation for possible contamination, and a compilation of historical records about 300 Area operations. This latter task included interviewing current and former personnel, and accumulating and analyzing old aerial photographs of the area. Radiation levels from an underground pipeline were higher than expected. The pipeline was used from 1954 to 1979 to 
transfer high-activity waste from the laboratories to storage tanks, from which the wastes were sent in rail cars to the 200 Area for disposal. The pipeline is known to have leaked, though monitoring wells show no spread of contamination to the soil. Preparations have begun to start vadose zone drilling, safety documentation and analysis, initial surface geophysics work has been completed, and a report has been issued.

Work started for the 300-FF-5 operable unit includes geophysical surveys of waste sites, archeological surveys of proposed borehole locations, equipment acquisition, preparation of computer models for risk assessment and field test specification, and initiation of drilling specifications in preparation for intrusive work which began in May 1991.

\section{0-HR-1/100-HR-3 Operable Units}

The 100-HR-1 is a source operable unit that occupies about 320 acres adjacent to the Columbia River in the northeast portion of the $100-\mathrm{H}$ Area, which is the site of the retired $1 \mathrm{CO}-\mathrm{H}$ Reactor and support facilities. Primarily due to the presence of the 183-H Solar Evaporation Basins, which will be closed under RCRA as a disposal facility, these operable units have been designated as RCRA past-practice sites and are being investigated under the RFI/CMS process. The 100-HR-3 is a groundwater operable unit that underlies and is potentially affected by $100-H R-1$ and possibly other sources. The RFI/CMS work plans for the 100-HR-1 and 100-HR-3 operable units were submitted for regulatory review in FY 1989. Comments were incorporated and the plans transmitted to DOE-RL in 1990. The DOE-RL submitted these plans to Ecology for comment incorporation review (and approval) in October 1990. Nonintrusive work is under way in the 100-HR-1 and 100-HR-3 operable units pending approval of the work plans.

\section{0-DR-1 Operable Unit}

The 100-DR-1 operable unit is about 380 acres in the north-central part of the Hanford Site, on the south bank of the Columbia River and about 3 n miles north-northwest of the city of Richland. The 100-DR-1 is a source operable unit associated with the 100-HR-3 groundwater unit. The operable unit includes the 105-D Reactor, operated from 1944 to 1967 , and associated facilities, including disposal cribs and trenches and retention basins. The operable unit also includes the 120-D-1 Pond and a waste disposal facility still used for filter backwash water. Consequently, the entire unit has been designated as a RCRA past-practice site and is being investigated under the RFI/CMS process, with Ecology as the lead regulatory agency. The work plan was submitted to Ecology in 1989. Comments have been incorporated and the work plan transmitted in 1990 to DOE-RL, which submitted the plan to Ecology for comment incorporation review (and approval) in 0ctober 1990. Nonintrusive work is under way pending approval of the work plan. 
100-NR-1/100-NR-3 Operable Units

The 100-NR-1 operable unit is an aggregate source/ground water operable unit. It occupies about 640 acres adjacent to the Columbia River in the northern part of the Hanford Site. The city of Richland is approximately 27 air and 38 river miles south of the 100-N Area. The $\mathrm{N}$-Area is bounded on the northeast by the 100-D Area; on the south ind southeast by the 600 Area; and on the southwest by the 100-K Area.

$\mathrm{N}$ Reactor was the last reactor to be constructed at the Hanford Site. It differs -from the other Hanford reactors in that it was designed as a dual purpose reactor capable of producing plutonium and steam. The steam was piped to the nearby Hanford Generating Plant where it was used to produce electrical power.

Ecology and the EPA have determined that the $N$-Area operable units will be addressed under RCRA corrective action authority with Ecology as the lead regulatory agency. The work plans have been written and are currently out for regulatory review.

\section{$100-B C-1 / 100-B C-5$}

The 100-BC-1 operable unit is about 450 acres in the northwestern portion of the Hanford Site adjacent to the Columbia River. It is a source operable unit containing the liquid and sludge disposal sites generally associated with the $\mathrm{B}$ Reactor. The $100-\mathrm{BC}-5$ is the groundwater operable unit that underlies and is potentially affected by the 100-BC-1 and other sources. The RI/FS work plans have been submitted for regulatory review. Comments have been incorporated and the plans resubmitted for a second regulatory review in January 1991.

\section{$100-K R-1 / 100-K R-4$}

The 100-KR-1 operable unit is about 400 acres in the northwestern portion of the Hanford Site adjacent to the Columbia River and northeast of the $B / C$ Reactor area. It is a source operable unit containing the liquid disposal sites associated with the KE and KW Reactors. The 100-KR-4 is a groundwater operable unit that underlies and is potentially affected by the 100-KR-1 and other sources. The RI/FS work plans have been submitted for regulatory review. Two rounds of comments have been incorporated and the plans were resubmitted to the regulators in February 1991. The plans are currently awaiting release for public comment. 


\section{B.6 - DECONTAMINATION AND DECOMMISSIONING}

\section{B.6.1 HANFORD SURPLUS FACILITIES PROGRAM}

The Hanford Surplus Facilities Program was established to perform safe, cost-effective surveillance, maintenance, and decommissioning of surplus facilities at the Hanford Site. Most of the surplus facilities at the Hanford Site were built in the 1940's as part of the Manhattan Project. Located in the 100, 200, and 300 Areas, they include production reactors, chemical separation/processing plants, waste-handling facilities, and ancillary/support structures.

To date, 35 contaminated facilities, including support facilities, stacks, and effluent systems, have been demolished/stabilized since 1983. The decommissioning effort has continued, with two major activities under way. These include the Strontium Semiworks and 183-H Solar Evaporation Basins.

The Strontium Semiworks was a pilot plant for the reduction oxidation and PUREX processes. Decommissioning of the Strontium Semiworks began in 1984 and was originally scheduled to be completed in FY 1989. The project was temporarily placed on hold pending an engineering $\mathrm{plan}$ to remediate three below grade waste tanks. These tanks, designated 241-CX-70, 241-CX-71, and 241-CX-72, are scheduled to be sampled, and based on the analysis, they will be stabilized or cleaned out as appropriate. The project work has resumed, and sampling of Tank 241-CX-71 was completed on schedule in October 1990. Analysis of the samples is ongoing. Wastes should be completely removed from Tank 241-CX-70 by September 1991 .

The 183-H Solar Evaporator Basins received liquid chemical and radioactive wastes from 300 Area fuel fabrication. The basins are near the Columbia River and groundwater beneath the basins has elevated levels of chromium and uranium. Cleanup and closure of the 183-H Solar Evaporation Basins began in FY 1986. A closure plan was submitted to Ecology in FY 1988. The closure plan requires removal of the remaining waste, routine sampling of the groundwater, and basin decontamination and demolition. The closure plan has been revised based on Ecology's comments and resubmitted to Ecology for approval. The public review process is still scheduled for 1991. Closure of the basins is scheduled for FY 1992. Postclosure care, including groundwater monitoring, will continue for 30 years following the demolition and closure.

We successfully completed removing waste from the basins on December 12 , 1990. The Phase I soil sampling from around and beneath the basins concluded on May 3. Current activities are focused on obtaining vadose zone and concrete samples from in and around the basins. 
Preparation of the Surplus Production Reactor Decommissioning-EIS* began in FY 1985. The Surplus Production Reactor Decommissioning-EIS addresses the decommissioning alternatives for ti.e eight surplus production reactors in the 100 Areas. The alternatives being considered include no action, immediate one-piece removal, safe storage followed by deferred dismantlement, and in situ or in-place decommissioning. The draft report was released to the public for a 90-day review that ended July 28, 1989. The DOE has reviewed the comments it received on the draft and prepared the draft final EIS. The draft final EIS is now at DOE-HQ for review and approval. The record of decision is scheduled to be issued in FY 1991.

Decommissioning of the current inventory of facilities in the Hanford Surplus Facilities Program is currently scheduled to be completed in approximately 28 years at an estimated total cost of $\$ 800$ million.

\section{B.6.2 DECOMMISSIONING EIGHT SURPLUS HANFORD REACTORS}

Eight plutonium production reactors were bui?t and operated at the Hanford Site between 1943 and 1971. These reactors $(D, C, D, D R, F, H, K E$, and $K W$ ) have been declared surplus by the DOE and are now available for decommissioning. A ninth reactor, $N$, is being placed in dry standby and is not yet surplus.

A draft EIS was issued on April 28, 1989, to address the alternative methods of decommissioning these sight reactors. Five alternatives were considered:

- No Action. The reictors are left in place and the present maintenance and surveillance programs are continued (a second No Action alternativ: of closing the facilities and doing nothing further is neither responsible nor acceptable and is not considered further). In 19! 0 dollars, the estimated cost of this option is $\$ 43$ million.

- Immediate One-Piec e Removal. The reactor buildings are demolished and the reactor blicks are transported in one piece on a tractortransporter across the site along a predetermined route to an onsite low-level waste burial area. In 1990 dollars, the total estimated cost of this option is $\$ 228$ million.

- Safe Storage Followed by Deferred One-Piece Removal. The reactors are temporarily stored in a safe, secure status for 75 years, after which the reactor buildings are demolished and the reactor blocks are transported in one piece on a tractor-transporter across the

"Draft Environmental Impact State, Decommissioning of Eight Surplus Production Reactors at the Hanford Site, Richland, Washington, DOE-EIS-0119D, March 1989, U.S. Department of Energy, Washington, D.C. 
site along a predetermined route to an onsite low-level waste burial area. In 1990 dollars, the total estimated cost of this option is $\$ 235$ million.

- Safe Storage Followed by Deferred Dismantlement. The reactors are temporarily stored in a safe, secure status for 75 years, after which they are fully dismantled and any remaining radioactive waste is transported to a low-level waste burial area on the Hanford Site. In 1990 dollars, the total estimated cost of this option is \$311 million.

- In Situ Decommissioning. The reactors remain at their present locations, contamination is immobilized, major voids are filled, potential pathways (openings such as large pipes, air ducts, and doors) are sealed, and an engineered mound of building rubble, earth, and gravel is constructed over the decommissioned reactor to act as a long-term protective barrier against human intrusion, water infiltration, and water and wind erosion. In 1990 dollars, the total estimated cost of this option is $\$ 193$ million.

The public outreach program was completed June 1989. The public hearings were completed in July 1989 and the record of decision is currently scheduled to be issued in 1991 .

\section{B.6.3 PLANNED DECOMMISSIONING WORK}

In FY 1992, decommissioning work will continue on the Strontium Semiworks tanks and the 183-H Solar Evaporation Basins. We will close or demolish the basins based on the approval closure strategy, which will be finished after public review of the closure plan and the soil and concrete sampling analysis. The waste in Tank 241-CX-72 will be sampled in FY 1992. We will develop removal alternatives based on the analytical results.

Detailed engineering for reactor decommissioning is scheduled to begin in FY 1992 based on receiving a record of decision in FY 1991. Preliminary engineering and characterization work will also begin in the 233-S Plutonium Concentration Facility and the $232-Z$ Waste Incineration Facility. 


\section{B.6.4 REACTOR OPERATING HISTORIES}

\begin{tabular}{c|c|c|c}
\hline $\begin{array}{c}\text { Reactor } \\
\text { facility }\end{array}$ & $\begin{array}{c}\text { Initial } \\
\text { startup date }\end{array}$ & $\begin{array}{c}\text { Final shutdown } \\
\text { date }\end{array}$ & $\begin{array}{c}\text { Years } \\
\text { operated }^{\text {act }}\end{array}$ \\
\hline B & $09 / 26 / 44$ & $02 / 13 / 68$ & $22^{\mathrm{b}}$ \\
C & $11 / 18 / 52$ & $04 / 25 / 69$ & 17 \\
D & $12 / 17 / 44$ & $06 / 26 / 67$ & 23 \\
DR & $10 / 03 / 50$ & $12 / 30 / 64$ & 14 \\
F & $02 / 25 / 45$ & $06 / 25 / 65$ & 20 \\
H & $10 / 29 / 49$ & $04 / 21 / 65$ & 16 \\
KE & $04 / 17 / 55$ & $01 / 28 / 71$ & 16 \\
KW & $01 / 04 / 55$ & $02 / 01 / 70$ & 15 \\
N & $12 / 31 / 63$ & $01 / 06 / 87^{c}$ & 23 \\
\hline
\end{tabular}

${ }^{a}$ Rounded off to years.

${ }^{b} B$ Reactor was shut down and held in standby status from $03 / 19 / 46$ to $06 / 02 / 48$, then restarted and operated until February 1968.

${ }^{c} \mathrm{~N}$ Reactor is in dry-standby status. 


\section{B.7 - FUTURE SITE USE STRATEGY DEVELOPMENT}

The DOE, other Federal, State, local, and tribal government officials, and members of the public recognize the need to articulate a vision for the future of Hanford. The vision will have an integral part in the transition from the defense mission of the past to the environmental restoration mission and other future new missions. Key parts of this vision are a strategy for cleanup and potential future uses of the land at Hanford. The three parties, in cooperation with other interested participants, are organizing a process to develop alternatives for a future site use and cleanup strategy.

The strategy will be a source of guidance ongoing at Hanford. Currently, the direction of cleanup is being set by DOE and the regulators. The guidance used to set that direction is based on technical judgment and on environmental regulations such as RCRA and Superfund.

This guidance is incomplete. Not all circumstances and substances encountered during Hanford cleanup are covered by regulations, nor does technology currently exist to implement all the regulations or handle all the contaminants. Another key item, essential to establishing the direction of Hanford cleanup, is also missing. That is a clearly defined goal for cleanup stated in terms that are clearly understood by everyone who has an interest in cleanup. The future site use and cleanup strategy will identify general goals for Hanford cleanup in terms of potential long-term site use categories for the Hanford Site.

The ultimate goal of cleanup is to protect public health and mitigate environmental damage from exposure to the contaminants at Hanford. That goal is not specific enough to implement without significantly more guidance. The guidance in a future site use/cleanup strategy can serve as the common denominator from which the key questions about how to implement cleanup can be answered.

The question "how clean is clean" for a given site can really only be answered when it is known whether wastes should be removed from the site and what the land at that site might be used for after cleanup is complete. For example, an area considered a valuable location for tribal gathering of natural foods and medicines could be a candidate for removal of wastes. Or, more of the contaminants may need to be removed from a site to protect public health if that site is to be used for agricultural purposes than if it is to be used for an industrial development. Conversely, it may not be a wise use of resources to restore a part of the site to pristine conditions if a hazardous waste landfill will eventually be located adjacent to it.

To develop the land use strategy, it will be necessary to understand all of the factors that affect 1 and use and cleanup. These include the following:

- Technical Capability. Technology does not currently exist to completely eliminate all contaminants or to clean up many of the sites to background level. There may even be some sites for which no treatment or remediation technology currently exists. It will be 
necessary to consider the status of currently available technology and make judgments about what may reasonably be available in the next 20 or 30 years.

- Public Health and Safety. Certain minimum levels of cleanup will be dictated by the need to protect people from undue risk associated with contaminants migrating from the waste sites at Hanford. Some consideration for what those levels of risk should be and how the level of risk from a given waste site is determined is necessary to develop a future site use and cleanup strategy.

- Public Expectations. Various sectors of the public have differing expectations about what Hanford lands should be used for after cleanup is complete. For example, members of the agricultural community might like the land to be used for irrigated agriculture. Native Americans might wish to exercise provisions of the Treaties of 1855 and applicable Federal statutes and have the land available for tribal use. Ecological interests might like to see the land preserved as wildlife and wilderness areas. Former landowners may wish that the land be returned to them. Many other groups (organized or not) have their own ideas about the future use of Hanford lands. In addition, some decisions, such as the direction of cleanup and the priority given to cleanup of selected sites can be made in the near future (5-10 years). Others, such as final disposition of parts of the land, may take longer. Part of the future site use and cleanup strategy development process should consider the timing of such decisions.

- Social Acceptability. Like public expectations, what is

'acceptable' depends on an individual's point of view. There may be some areas where there will be common ground for all parties. One example might be the remoyal of contamination along the Columbia River shoreline. There are many areas in which there will be significant diversity among opinions. In addition, groups not directly involved with Hanford cleanup and future use decisions will help define what is socially acceptable. For example, host states for geologic repositories and other waste disposal facilities may not be willing to accept the large amount of waste that would be produced if the entire site were to be returned to pristine condition (assuming that were otherwise possible.)

- Cultural Considerations. Native Americans have used portions of the land at Hanford for hunting, fishing, gathering, and social and religious activities for centuries. Religious and cultural sites important to the tribes are located on the Hanford Site. Congress has enacted laws such as the Archaeological Resources Protection Act, the National Historic Preservation Act, and the American Indian Religious Freedoms Act in an effort to protect the cultural resources of the Native Americans. Respect for the Native American way of 1 ife, as well as the Treaties of 1855 , require that careful consideration be given to tribal legal rights and heritage when making decisions about potential future uses. 
- Ecological Considerations. Several threatened or endangered (or potentially threatened) species and unique habitats are located at the Hanford Site. For example, bald eagles are frequent visitors to the Hanford Reach of the Columbia River. Wild salmon spawning grounds are also located on the Reach - - several species of wild salmon are being considered for listing under the Federal Endangered Species Act. One of the last remaining sagebrush steppe habitats in the world is at Hanford. In addition, Public Law 100-605,

commissioned the Hanford Reach Study. The National Park Service will recommend to Congress in November 1991 what protective measures should be taken for the Hanford Reach of the Columbia River.

- Legal Rights and Obligations. Compliance with treaties, laws, regulations, and other legal obligations must be factored into cleanup and future use decisions. These include, but are not limited to, environmental laws, such as RCRA or Superfund; the Treaties of 1855; cultural resource protection laws, such as the Archaeological Resources Protection Act, the American Indian Religious Freedoms Act, and the National Historic Preservation Act; Federal and State regulations relating to the implementation of environmental laws, Federal property management, disposal of high-level and transuranic wastes, etc.; and leases currently held with the State of Washington, the Washington Public Power Supply System, and others.

- Current Land Uses. Hanford Site I ands are currently being used for a number of federal programs, including environmental and energy research and development, ecological preservation, waste management and disposal, and defense programs. Current and potential future uses to support these and other potential future national needs must be factored in to cleanup and future use decisions. Socioeconomic issues associated with potential future uses may also be a factor.

- Suitability. Suitability criteria should be considered when determining future use categories. These include soils, geology, topography, utilities, transportation, existing and adjacent uses, recreational values, natural and cultural resource values, air quality, water quality and availability, etc.

- Costs. The cost of cleanup is estimated to be in the tens of billions of dollars and is expected to rise as more information becomes available about waste sites. The taxpayers will not support unlimited growth in cleanup costs. Some tradeoffs may have to be made to make cleanup affordable to taxpayers.

The development of this strategy will occur as part of the Hanford Remedial Action (see Section B.12.2). The purpose of the Hanford Remedial Action EIS is to address the complex issues associated with cleanup of atiout 1,100 waste sites at the Hanford Site. The development of the strategy as part of this EIS will provide the framework for many future decisions made at the site related to cleanup, future development of the site, placement of potential future facilities, and potential disposition of the land for non-DOE uses. 
Preparation of this EIS will use extensive public involvement to establish reasonable alternatives for the future site uses/cleanup strategy. It is envisioned that the strategy will actually consist of two parts - - the overall cleanup strategy and the future site use categories. Each of the parts would look at the entire site, by the six major geographical areas of the site.

- 100 Area. The site of the retired reactor facilities, located along the Columbia River in the northern central part of the site.

- 200 Areas. The sites of the chemical processing and waste management and disposal facilities, located on a plateau in the center of the site.

- 300 Area. The site of fuel fabrication and research and development activities, located along the Columbia River in the southeastern part of the site.

- 400 Area. The site of the Fast Flux Test Facility located in the southern central part of the site.

- $1100 / 3000$ Area. The site of maintenance, construction, and site support activities, located adjacent to the city of Richland in the extreme southern part of the site.

- 600 Area. The remainder of the site not included in the other organized areas, including the Arid Lands Ecology Reserve, south of Highway 240 to the crest of Rattlesnake Mountain; the Wahluke Game Preserve and Saddle Mountain Wildlife Refuge, located north of th.e Columbia River; the open tracts of land in the central part of the site, including that part occupied by the Washington Public Power Supply System's commercial reactor facilities.

For the first part of the EIS, alternative cleanup strategies considered for each of the six areas could include: stabilization in place, with or without groundwater monitoring and stabilization; removal to onsite waste disposal facility, with or without groundwater cleanup; removal to offsite repositories, with or without groundwater cleanup; or no cleanup.

For the second part of the EIS, future site use categories for the major geographical areas could include:

Unrestricted. No restrictions on use of that portion of the site would result from wastes or other contamination left behind by the Hanford cleanup actions. Any specific land use (i.e; agricultural, residential, research and development, etc.) could fit into an unrestricted future use category.

- Restricted. Some permanent restrictions on possible future use of that portion of the site result from waste sites or contamination remaining after cleanup has been completed. The restrictions would be placed to prevent human exposure to levels of radioactivity or 
hazardous chemicals higher than allowable exposure standards. Isolation of the restricted part of the land (surface or subsurface soils or groundwater) would be accomplished to prevent migration to unrestricted areas.

- Exclusive. That portion of the land would be dedicated for the disposal of radioactive or hazardous wastes. No other future uses would be permitted. The surface and subsurface soils and groundwater would be permanently monitored and isolated to prevent migration to unrestricted or restricted areas.

It is important to note that the actual contents and structure of the Hanford Remedial Action EIS is highly dependent on the input received from extensive public involvement processes. The alternatives suggested above are possibilities which should be considered and may be altered as a result of public involvement during the scoping and alternative development process. The intent of this process is for the working group to ident ify a reasonable number of alternatives which would be evaluated in the EIS. DOE may choose to evaluate additional alternatives as well. Under the National Environmental Policy Act, DOE is responsible for selecting alternatives and making final decisions.

Representatives of DOE, EPA, the National Park Service, the States of Washington and Oregon, the Yakima Indian Nation, the Confederated Tribes of the Umatilla Indian Reservation, and Benton, Franklin, and Grant Counties met in November 1990 to begin planning. The DOE, EPA, and the State of Washington took an action to find and jointly fund an external, independent facilitator to help the group design a process for development of the alternatives. The facilitator should be on board in summer 1991 and the challenge of developing future site use cleanup strategy alternatives will begin in earnest. 


\section{B.8 - ENVIRONMENTAL MONITORING AT HANFORD}

\section{B.8.1 ENVIRONMENTAL MONITORING PROGRAM}

Environmental monitoring of the Hanford Site and annual reporting of results are conducted in accordance with guidance from DOE Orders 5480.1B, $5484.1,5400.1$, and 5400.5. Environmental monitoring provides for the measurement and interpretation of the impact of Hanford Site operations on the public and the onsite and offsite environment. The annual Hanford Site Environmental Report is normally distributed by June 1 of each year to all interested parties. The 1989 report has been distributed, and the 1990 report is being prepared. The 1989 results are summarized in Section B.8.2.

Samples are collected and radiation is measured according to three zones from main onsite operating areas to the offsite environs. The first zone extends from operating facilities to the Site perimeter. Air monitoring stations surround each operating area because air transport is a critical pathway for rapid transport of radioactive materials. Groundwater is sampled from wells near operating areas and along potential transport pathways. In addition, samples of soil, native vegetation, and wildlife are collected and radiation measured to determine the effectiveness of effluent controls and to detect any buildup of radioactive materials from long-term operations.

The second monitoring zone includes a series of sampling stations and groundwater monitoring wells positioned around the Hanford Site perimeter. Both hazardous chemical and radiological concentrations are measured in groundwater samples. Milk, crops, soil, and native vegetation are monitored to detect any influence from the Hanford Site on locally produced food and farm products. The Columbia River is monitored upstream of the Hanford Site and at Richland where it is used for public drinking water. Water pumped from the river for irrigation is also monitored. The U.S. Geological Survey monitors water quality at the Priest Rapids Dam and at Richland.

The third monitoring zone consists of locacions within a 80-kilometer radius of the Hanford Site. Monitoring at communities provides an assurance to the public that Hanford Site effluents are monitored and radionuclide concentrations are recorded at populated areas. Distant locations are also monitored to provide data to compare with data collected from the Hanford Site perimeter and onsite locations. Routine environmental sample types and measurement locations are shown in Table B-3.

The potential radiation doses received by the public are calculated from environmental monitoring data when Hanford-related radionuclide concentrations are measurable. However, data from the offsite environs and communities near the Hanford Site usually do not indicate a measurable effect from Hanford Site operations. When concentrations are too low to be detected by monitoring, potential radiation doses to the public are calculated using data from effluent measurements and computer models. The computer models are specific to the Hanford Site and vicinity and include local dietary habits and recreational use of the Columbia River. These models simulate the movement of 
radioactive materials through the environment, food pathways, and consumption by the public, and estimate the resulting radiation dose.

Table B-3. Routine Environmental Sample Types and Measurement Locations.

\begin{tabular}{|c|c|c|c|c|c|}
\hline & \multicolumn{5}{|c|}{ Sample locations } \\
\hline & $\begin{array}{c}\text { Total } \\
\text { number }\end{array}$ & Onsite & Derimeter & $\begin{array}{c}\text { Nearby } \\
\text { communities }\end{array}$ & $\begin{array}{c}\text { Distant } \\
\text { communities }\end{array}$ \\
\hline Air & 53 & 24 & 14 & 9 & 6 \\
\hline Groundwater & 567 & 567 & & & \\
\hline Columbia River & & & 2 & 2 & \\
\hline Irrigation water & 1 & & 1 & & \\
\hline Drinking water & 14 & 9 & 5 & & \\
\hline $\begin{array}{l}\text { Columbia River } \\
\text { sediments }\end{array}$ & 5 & & 3 & 1 & 1 \\
\hline Ponds & 3 & 3 & & & \\
\hline Foodstuffs & 8 & & 5 & 1 & 2 \\
\hline Wildlife & 17 & 14 & 3 & & \\
\hline Soil and vegetation & 38 & 15 & 14 & 3 & 6 \\
\hline Dose rate & 88 & 34 & 39 & 9 & 6 \\
\hline Waste site surveys & 73 & 73 & & & \\
\hline Railroad/roadway survey & 17 & 17 & & & \\
\hline Shoreline survey & 27 & & 27 & & \\
\hline Aerial survey & 1 & & 1 & & \\
\hline
\end{tabular}

\section{B.8.2 CURRENT RADIOACTIVE RELEASES TO THE OFFSITE ENVIRONMENT}

The Hanford environmental monitoring program includes the measurement of radioactivity in environmental media on and around the Hanford Site. Environmental measurements ard evaluations are performed on the following areas:

- Penetrating radiation

- Air

- Soil and vegetation

- Food and farm products

- Wildlife

- Columbia River water

- Groundwater 
- Air and water effluents

- Dose impact.

A summary of monitoring results from the Hanford Site Environmental Report for Calendar Year 1989, PNL-7346, are as follows.

\section{Penetrating Radiation}

There is no indication of any Hanford contribution to the offsite penetrating radiation dose. Some onsite locations near waste storage and handling facilities have levels that are higher than background but still below DOE Radiation Protection Standards.

Air

Measurements of radioactivity in air at the site perimeter show concentrations to be near background and far below a 11 DOE and EPA guidelines. Air concentrations for tritium and iodine-129 at the downwind perimeter location were statistically higher than at an upwind distant location. These differences are likely due to site operations. However, even the maximum single perimeter sample for any radionuclide was only 0.1 percent of the applicable DOE Derived Concentration Guide. Annual average $\mathrm{NO}_{2}$ concentrations at all sampling locations were less than 14 percent of Federal and Washington State ambient air standards.

\section{Soil and Vegetation}

There is no indication of buildup of radioactivity off the Hanford Site attributable to past or current operations.

\section{Food and Farm Products}

The levels of radionuclides in farm products in the Hanford Site vicinity that could be influenced by irrigation with Columbia River water or Hanford air emissions show coricentrations similar to background at distant locations. The one exception to this is the iodine-129 in milk. Concentrations of iodine-129 in milk at the perimeter of Hanford is higher than concentrations at distant background locations. The concentrations is very low and far below all DOE and EPA standards.

\section{Wildlife}

Concentrations of radioactivity in wildlife on the Hanford Site are mostly at background concentrations. Some elevated concentrations are observed from burrowing animals such as rabbits that are collected in the vicinity of underground disposal sites. Concentrations are such that if these animals were consumed, the dose would be below applicable standards. 


\section{Columbia River Water}

The radionuclide concentrations in the Columbia River downstream of the Hanford Site are far below all EPA and Washington State drinking water standards.

\section{Groundwater}

Groundwater concentrations exceed the Safe Drinking Water Act standards for tritium and nitrate in the 100, 200, 300, and 600 Areas, and near the old Hanford townsite. Other pollutants that exceeded drinking water standards near operating areas included chromium, cyanide, carbon tetrachloride, and trichloroethylene. Also, the standards are exceeded for tritium, ${ }_{90}^{60}$ cobalt, ${ }^{90}$ strontium, ${ }^{99}$ technetium, ${ }^{129}$ iodine, and ${ }^{137}$ cesium near operating areas. Onsite drinking water supplies meet the drinking water standards.

\section{Air and Water Effluents}

Effluents from the Hanford Site operations are continually monitored. The major nuclides in 1989 airborne effluents were $180 \mathrm{Ci}$ of hydrogen-3 (tritium) and $1,600 \mathrm{Ci}$ of radon-220. Airborne effluents contained approximately $0.11 \mathrm{C} i$ of iodine-129. The major effluents to the Columbia River were $1.7 \mathrm{Ci}$ of strontium-90 and $74 \mathrm{Ci}$ of tritium.

\section{Dose Impact}

In 1989, the radiation dose from all pathways was $0.05 \mathrm{mrem}$ from all pathways. The average per capita dose was $0.004 \mathrm{mrem}$. These values compare to the DOE standard of 100 mrem per year for the maximally exposed individual.

Further detail on the environmerital status of the Hanford environment can be obtained from Hanford Site Environmental Report for Calendar Year 1989, PNL-7346.

\section{B.8.3 GROUNDWATER MONITORING}

The status of groundwater monitoring activities, issues, special related topics of current interest, and recent interpretive information are summarized below.

\section{Special One-Time Sampling Activity}

Sampling and analysis at 53 selected wells were completed during the last quarter at sites that are in the assessment mode for RCRA or have shown trends in the past. This was a limited, one-time sampling effort to obtain groundwater data during the period of extended negotiation of the replacement 
analytical services contract. In an April 1991 letter to DOE-RL, Ecology requested that full-scale RCRA monitoring activities be reinitiated within 45 days. Ecology noted that failure to comply would trigger "other administrative alternatives" to ensure compliance with state and Federal hazardous waste regulations.

The Office of Sample Management has received and validated some of the analytical results from the offsite contract laboratories used for this sampling. Interpretive highlights of these early arrivals are noted below.

\section{KE Fuel Storage Basin}

Concentrations of tritium in samples from two of four wells next to this facility are within the range of levels that have persisted for several years (e.g., approximately $700,000 \mathrm{pCi} / \mathrm{L}$ in the well with the highest concentration, compared with a drinking water standard of $20,000 \mathrm{pCi} / \mathrm{L})$. The source that sustains this localized groundwater contamination in the $100 \mathrm{~K}$ Area remains obscure. As part of the aggregate area data review for the 100 Area, an investigation of possible sources and near-field hydrologic characteristics of the site is planned.

\section{$216-\mathrm{A}-10 \mathrm{Crib}$}

This crib received process condensate (or distillate) from PUREX until it was replaced by the 216-A-45 Crib in 1987. Tritium concentrations in a key well at this site have declined from a maximum of $7,000,000 \mathrm{pCi} / \mathrm{L}$ in 1986 to $1,370,000 \mathrm{pCi} / \mathrm{L}$ in March 1991. PUREX process condensate is one of the principal sources of tritium in groundwater that moves northwest as well as southeast of PUREX and can be considered the source of the tritium plume (Figure $B-2$ ).

\section{6-B-62 Crib}

Located northwest of B Plant in the northwestern quadrant of 200 East Area, this crib received $B$ Plant process condensate until 1986. Rapidly increasing tritium concentrations were observed in a key well at this site between 1987 and 1989 , reaching an apparent maximum of $180,000 \mathrm{pCi} / \mathrm{L}$. Recent results (March 21, 1991) from the special sampling effort indicate a decline to $35,000 \mathrm{pCi} / \mathrm{L}$. Since this crib did not receive significant amounts of tritium, and has been in standby mode since 1986, the source may be the tritium plume spreading northwest from PUREX (see Figure B-2). This illustrates the difficulty in evaluating groundwater contamination in the 200 Areas at the operable unit or disposal facility scale of investigation. 
Figure B-2. Tritium Concentrations in the Hanford Site Unconfined Aquifer in 1989.

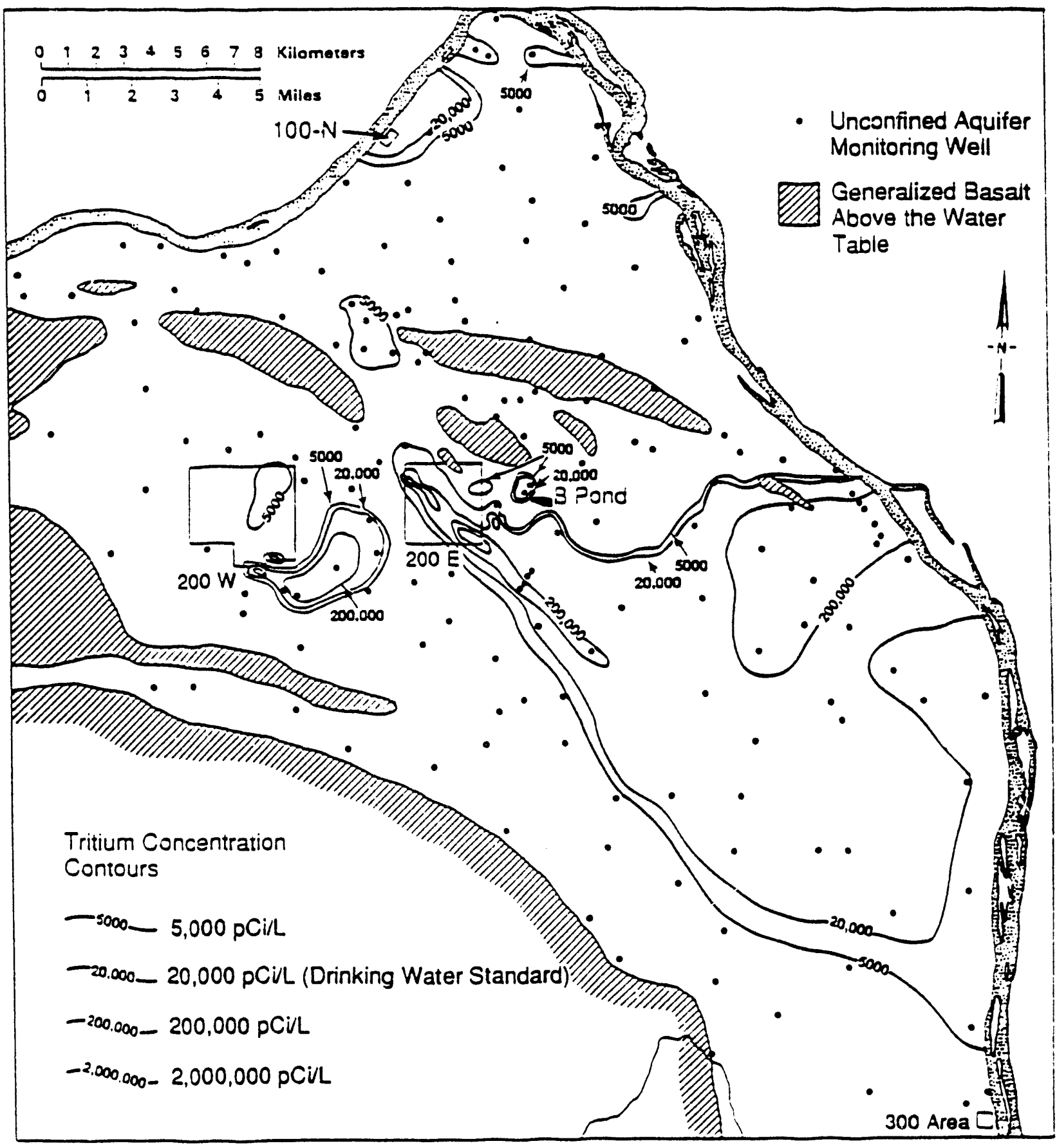

79103125.2 


\section{$216-z-20 \mathrm{Crib}$}

Wastewater from the Plutonium Finishing Plant is discharged to this crib (see Section A.10). Continued disposal of Plutonium Finishing Plant wastewater is required to maintain safety systems and for low-level waste disposal. Recent sampling resulis from two wells monitoring this crib confirm the presence of elevated carbon tetrachloride and chloroform (150 to $1,200 \mathrm{ppb}$ and 13 to $50 \mathrm{ppb}$, respectively). The new groundwater quality standards (WAC 173-200) for these constituents are $0.3 \mathrm{ppb}$ for carbon tetrachloride and $7.0 \mathrm{ppb}$ for chloroform. The occurrence of these constituents beneath the crib is attributed to residual solvent waste discharged to the adjacent cribs between 1955 and 1973, since only very low concentrations have been found in the plant's liquid effluent. A possible groundwater contamination pathway may involve absorption of carbon tetrachloride and chloroform vapor in the soil by the wastewater as it spreads laterally and migrates downward near the residual solvent source(s). Recent soil vapor extraction tests at the 216-Z-1A Crib, about $150 \mathrm{~m}$ west of the crib, confirm the presence of high soil vapor concentrations. It is hoped remediation by soil vapor extraction for the Expedited Response Action at this site may reduce this source of chlorinated hydrocarbons in groundwater (see Section A.7.4).

In addition to the carbon tetrachloride issue at this active disposal site, EPA and Ecology requested additional information concerning the status of transuranics in the soil column and groundwater. Additional characterization work began during the last quarter to provide this information and/or to support a waste discharge permit. Preliminary results from spectral gamma logs for wells next to the crib and radioanalysis of drill cuttings from a new well near the south end of the crib are consist $n$ t with discharge records. The records indicate only very small quantities of transuranics were added to this crib. In addition, americium and plutonium isotopes in groundwater from the two monitoring wells at this site (sampled on March 20, 1991) were not present at detectable levels (i.e., $<0.05 \mathrm{pCi} / \mathrm{L}$ ). These initial findings were discussed with EPA and Ecology on May 20, 1991.

\section{RCRA Sites}

The one-time special sampling results for RCRA sites in the assessment mode will be highlighted next quarter after more of the analytical results have been received and evaluated.

- Carbon Tetrachloride Plume in 200 West Area--Groundwater sampling in the 200 West Area was supplemented last quarter for the carbon tetrachloride expedited response action and special one-time, interim sampling. The sampling provided new chlorinated hydrocarbon data from some new RCRA well locations and confirmed previous measurements from others. This new data was combined with existing data for the period from 1989 to the present to update the carbon tetrachloride plume shown in Figure $B-3$. The distribution pattern reveals a high concentration "core" in the general northerly direction of groundwater filow away [downgradient] from the source areas ( $Z$ cribs). The core is surrounded by a low-concentration 
"halo" that extends beyond the 200 West boundary, suggesting a total area of more than $10 \mathrm{~km}^{2}$ that is above the $0.3 \mathrm{ppb}$ standard. Characterization of the source and evaluation of remediation options are under way.

- Superfund Groundwater Characterization--Sampling and analysis for the 1100-EM-1 and 200-BP-1 operable units continues on schedule. offsite analytical services vendors analyze samples collected at approximately 71 wells. General groundwater-related findings are reported el sewhere. Selected hydrochemical results from these programs are integrated with other groundwater monitoring data for larger-scale studies as appropriate and for preparation of sitewide plume maps.

In addition to the above, groundwater characterization activities are in progress for the 100 Aggregate Area (see Figure B-1). The activity is to be completed by the end of FY 1991 and includes:

- Compiling existing water table elevation, geologic and hydrochemical data

- Investigating the fitness-for future use of existing wells

- Summarizing existing informistion on the interactions between groundwater and the Columbia' River.

Results of this characterization work will help us plan the number and location of new monitoring wells as well as support other topics.

Westinghouse Hanford has proposed to DOE-RL an integrated groundwater investigation for the region that includes the 200 East and 200 West Areas. In addition to synthesizing existing information, it would allow a limited expansion of current groundwater sampling and analysis programs. The proposal al so includes reconnaissance of selected wells using the spectral gamma logging system to assess the occurrence and distribution of radionuclides in the soil column at or near suspected sources.

- Selected Groundwater Plume Maps--Groundwater contaminant plume maps based on previous data and interpretations are shown in Figures B-4 through $B-10$. These plots provide a general view of the location and extent of more localized contaminant plumes. 
Figure B-3. Contour Map of the Carbon Tetrachloride Plume.

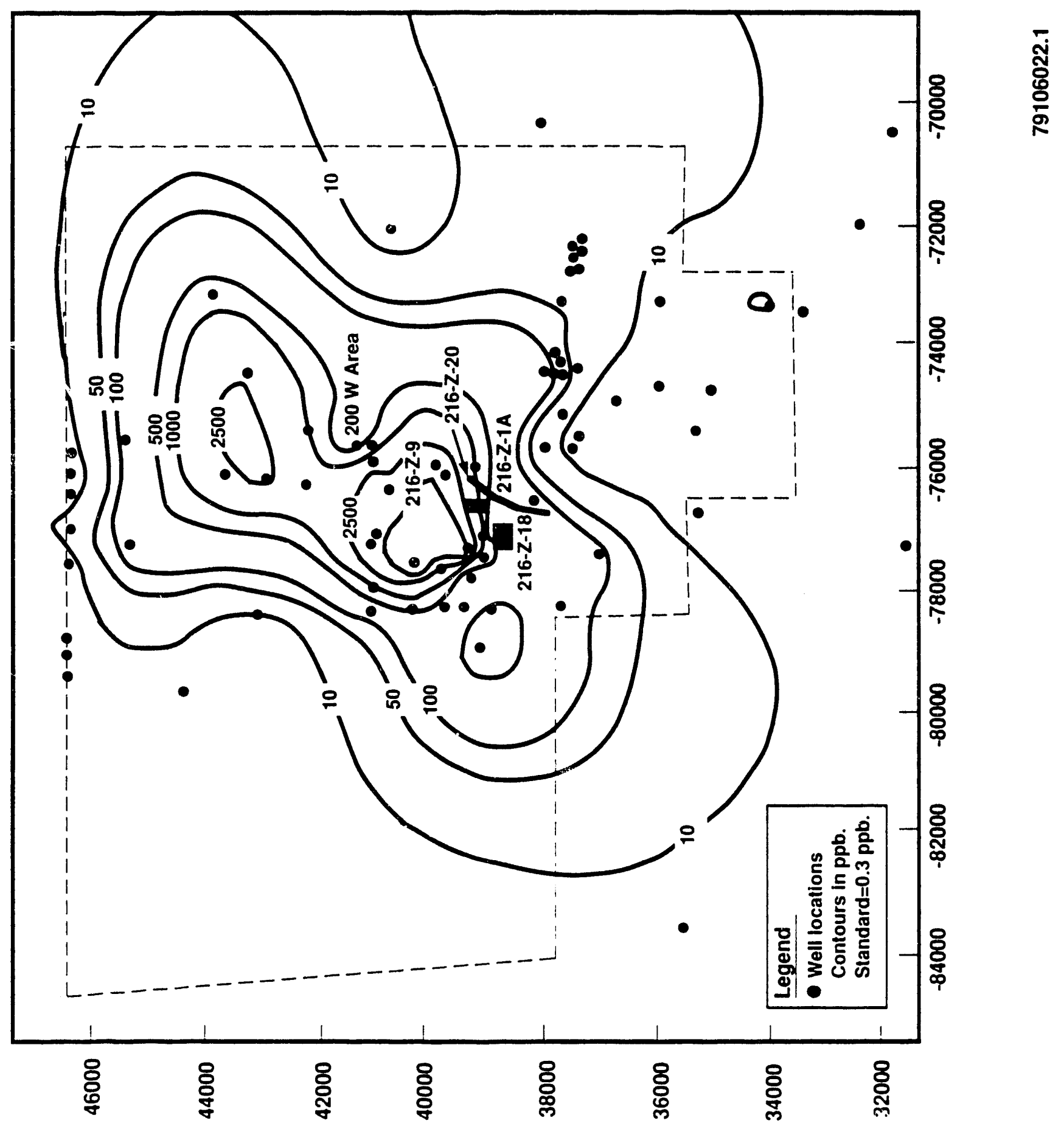


Figure B-4. Nitrate $\left(\mathrm{NO}_{3}\right)$ Concentrations in the Hanford Site Unconfined Aquifer in 1989.

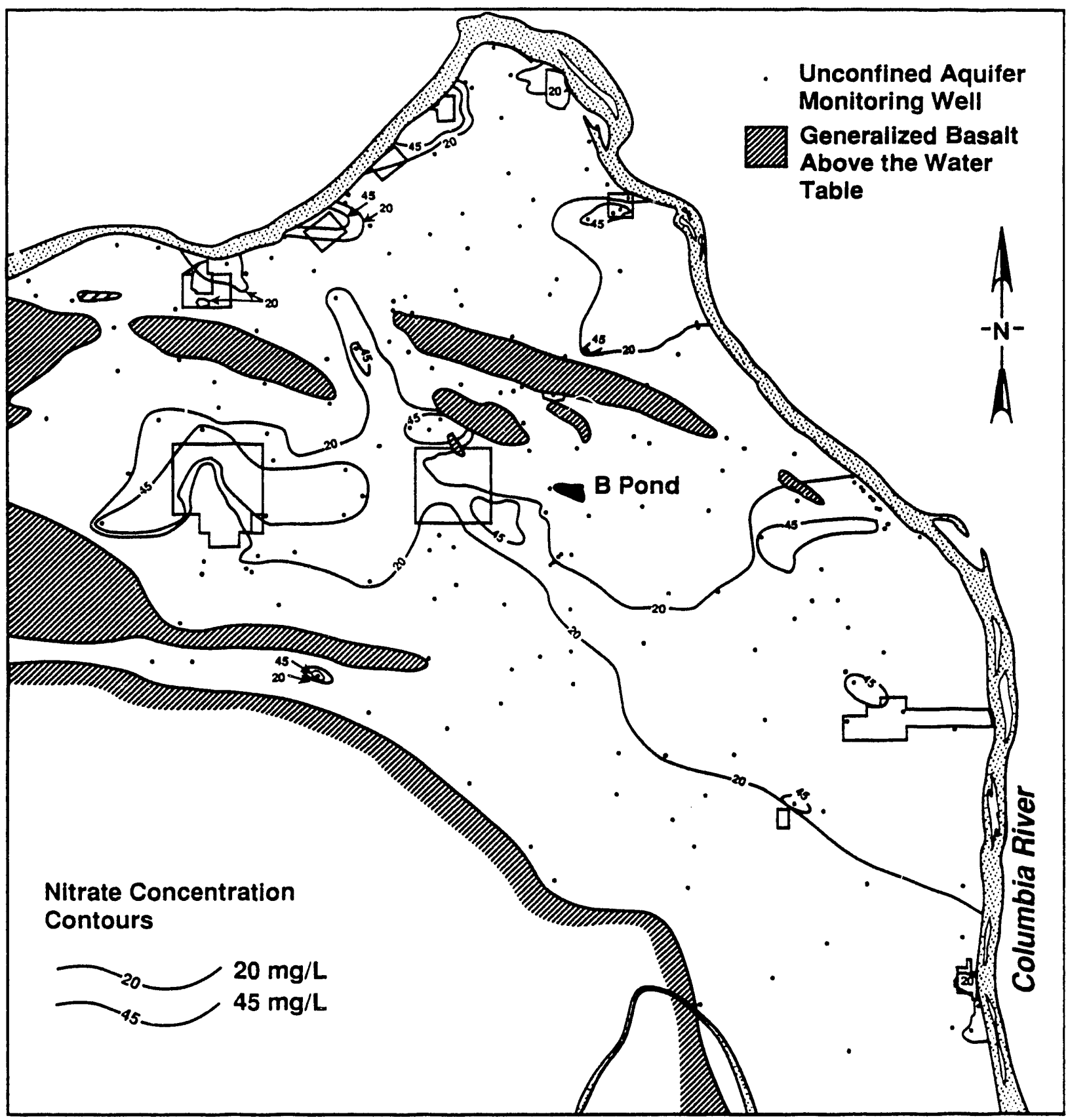

79103125.2 
Figure B-5. Uranium Plumes in the 300 Area.

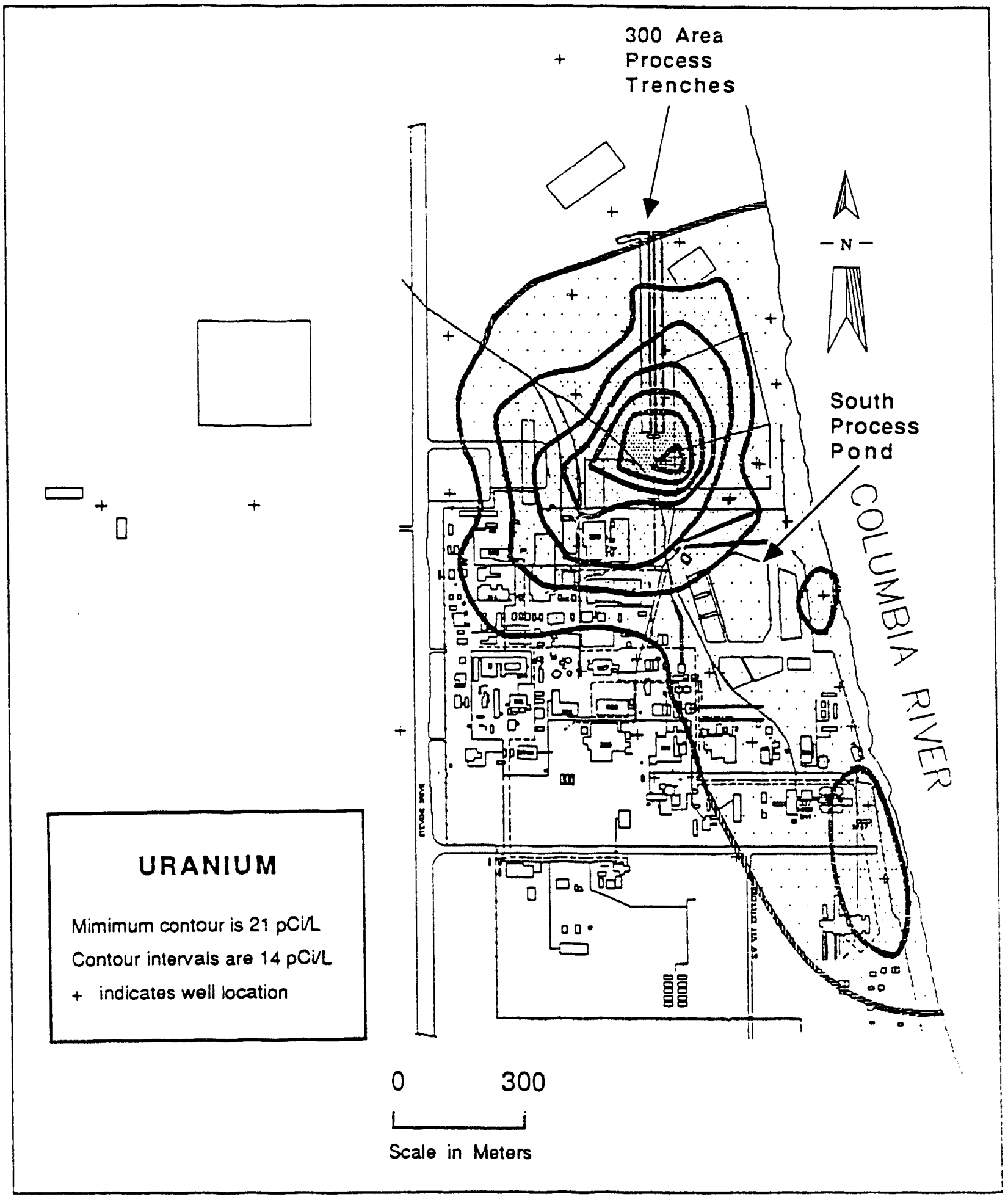


Figure B-6. Average Chromium (filtered sample) During 1990.

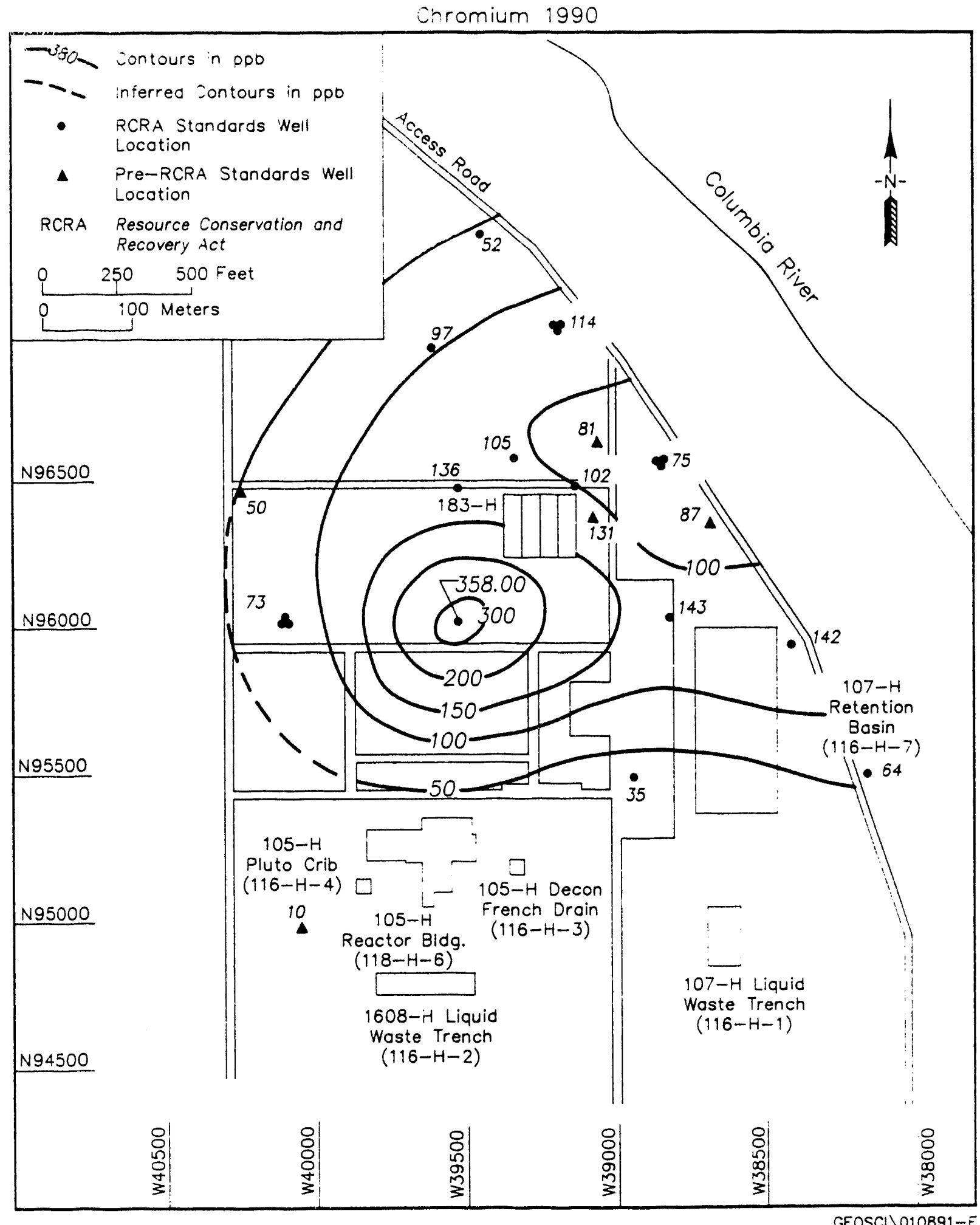


Figure B-7. Strontium-90 Plume in the 200 East Area.

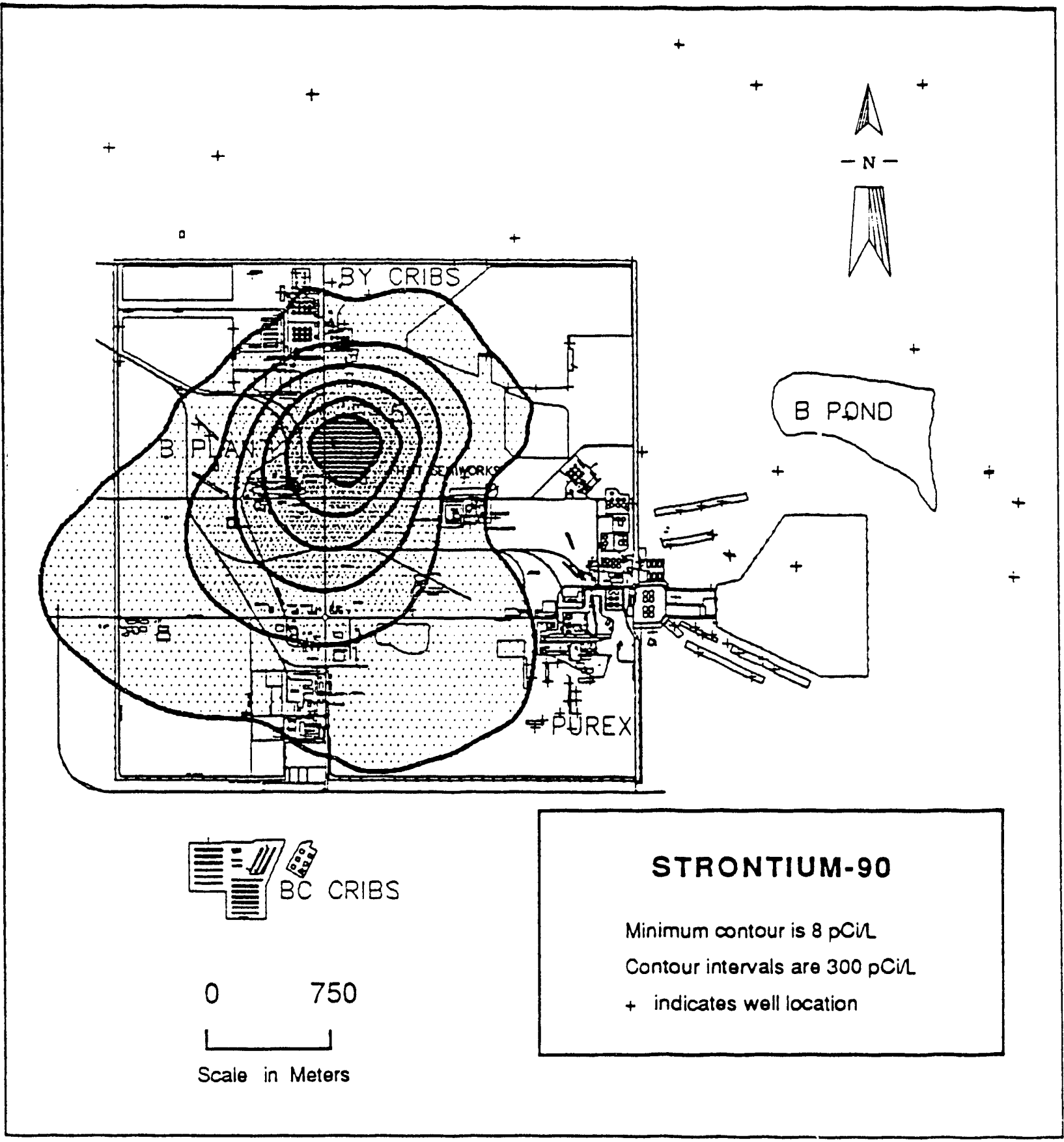


Figure B-8. Iodine-129 Plume in the 200 West Area.

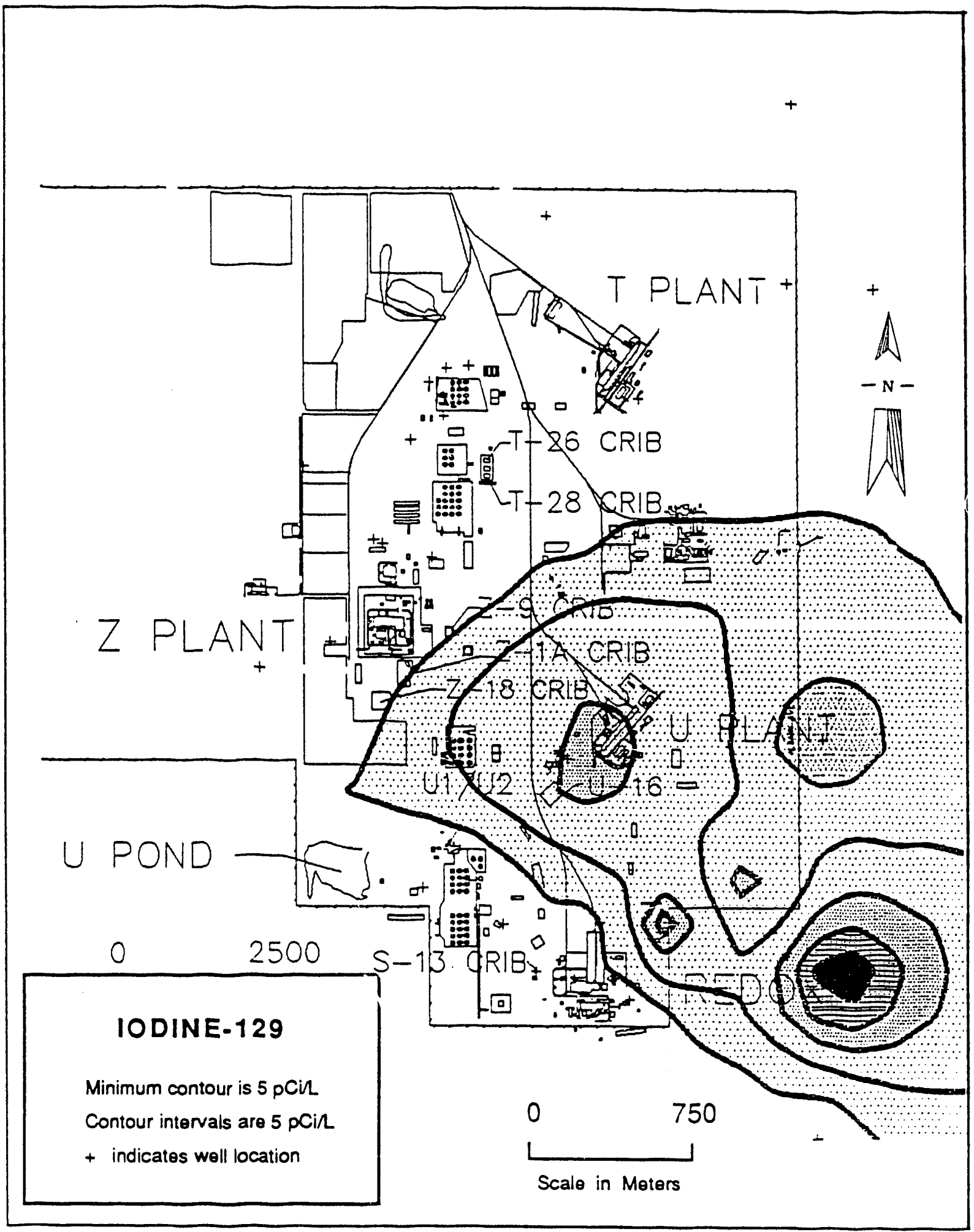


Figure B-9. Technetium-99 Plume in the 200 West Area.

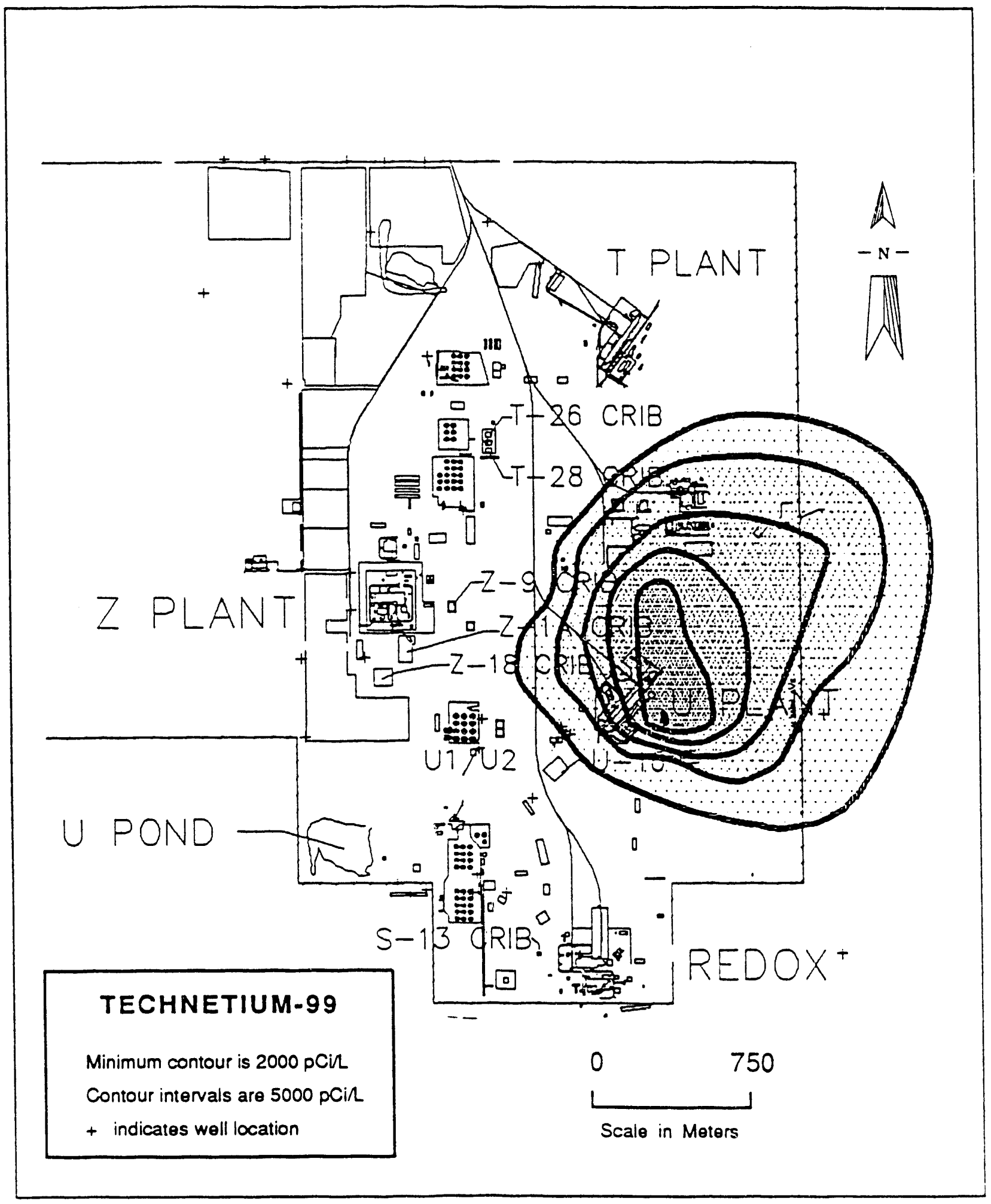


Figure B-10. Contour Map of the Carbon Tetrachloride Plume.

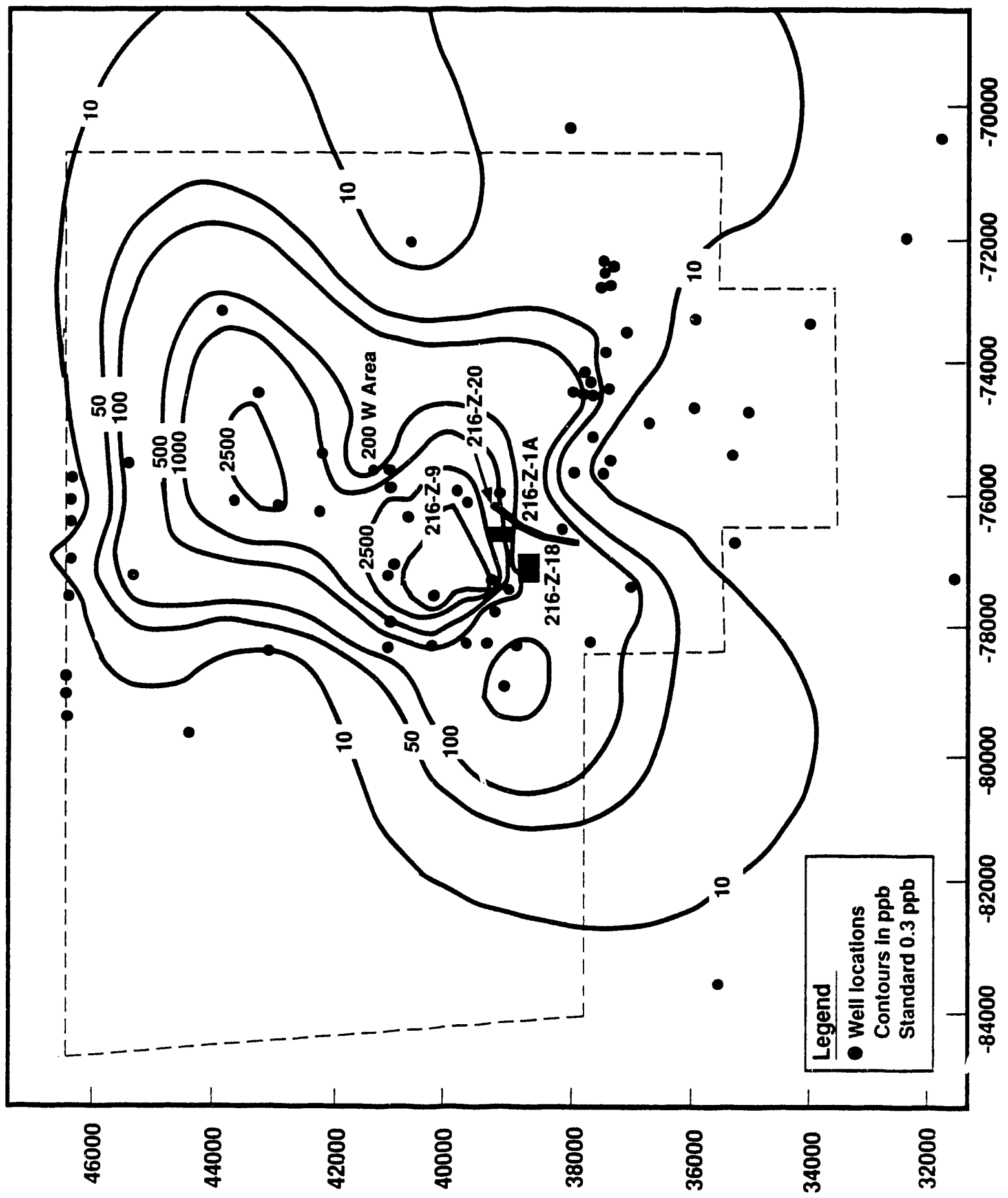


Contaminated areas that are more limited in distribution may be potential candidates for pump and treat remediation. For example, recent bench-scale tests to remove uranium and chromium from Hanford Site groundwater using patented sorbents (such as an algal byproduct fixed in an inert matrix) were successful. Test waters for these studies were collected near the 300 Area process trench at the head end of the uranium plume and from near the center of a mini-plume of chromium-containing groundwater near the $183-\mathrm{H}$ Solar Evaporator Basin (see Sections A.7.3 and B.6.1). This work was sponsored by the Technology Development Program. Westinghouse Hanford scientists are evaluating this technology for potential near-term application at Hanford. Pump and treat schemes for the more localized and high concentration portions of contaminant plumes (see Figures B-5 through B-10*) may be implemented via expedited response actions and/or during the scheduled RI/FS phase of Superfund site investigations.

"Hanford Site Ground-Water Surveillance for 1989, June 1990, PNL-7396, Evans, J. C., R. W. Bryce, D. J. Bates, and M. L. Kemner. 


\section{B.9 - COMPLIANCE ORDERS AND NOTICES OF VIOLATION}

Since 1984, Hanford has received nine compliance orders or notices of violation from the Ecology or EPA Region 10. Required corrective actions have been implemented in accordance with the ordem: or consent agreements negotiated after the orders. Hanford has recuived only three orders or notices since June 1989. The first two were formal Notices of Violation received from Ecology in June and August 1989, and the third, also issued by Ecology, was called a Notice of Noncompliance. A summary of these notices and the corresponding response by Hanford follows.

June 1989

Ecology issued a Notice of Violation within the following two areas based on its inspection of the 183-H Basins and the 216-S-10 Pond and Ditch.

- A continuous single-stand rope fence with appropriate warning signs around the 216-S-10 Pond and Ditch needed to be constructed.

- Two corroded and leaking drums containing mixed waste located at the 183-H Basins needed to be stabilized.

A single-strand barrier rope was installed with appropriate warning signs around 216-S-10 Pond and Ditch. The contents of the two leaking drums were removed and repackaged in appropriately prepared drums. The damaged drums were cut up and packaged in a similar manner. An inspection was conducted on the other drums containing dangerous waste at the $183-\mathrm{H}$ facility and no irregularities were noted. The Central Waste Complex, which receives 183-H dangerous waste drums, was inspected and no irregularities were noted. An analysis also was conducted on the probable cause of the corrosive material found on the drums. The results of this analysis were presented to Ecology.

\section{August 1989}

Ecology issued a Notice of Violation within the following three areas based on their inspection of the 216-A-29 Ditch, 216-B Pond and the Central Waste Complex.

- Need to construct at a minimum, a continuous single-strand chain fence with appropriate warning signs around the 216-A-29 Ditch.

- Four radiation warning signs were found unsecured on the ground near the 216-A-29 Ditch and 216-B Pond facilities.

- Ten waste drums that had exceeded the 90-day accumulation period while at the generating facility were found at the Central Waste Complex. 
A continuous single-strand barrier was installed around the 216-A-29 Ditch and 216-B Pond. The unsecured signs have been reposted. Periodic inspections will be conducted to identify necessary corrective actions such as unsecured signs.

The 10 drums were partially characterized and properly stored at the Central Waste Complex. A letter identifying the dangerous and mixed waste satellite and less-than-90-day accumulation areas on the Hanford Site was transmitted to Ecology.

\section{December 1990}

On December 10, 1990, Ecology notified DOE-RL and Westinghouse Hanford of a Notice of Noncompliance for returning 68 problem drums from the Central Waste Complex to the generator, the 183-H Basins. Ecology did not take any formal action, but requested that the 68 drums be repackaged and returned to the Central Waste Complex before December 25, 1990.

DOE-RL received concurrence from Ecology to extend the deadline to January 15, 1991. The repackaging of the drums began on December 18; however, this effort was hampered by bad weather. Eight additional working days were lost. All 68 of the problem drums were later repackaged and returned to the Central Waste Complex by January 25, 1991. Ecology was both verbally notified by Westinghouse Hanford and officially notified by DOE-RL of this additional delay. The remaining 1,600 problem drums will be repackaged or overpacked at the Central Waste Complex without being returned to the 183-H Basins. 


\section{B.10 - EXTERNAL PARTICIPANTS IN HANFORD CLEANUP}

\section{B.10.1 ROLE OF INDIANS AT HANFORD}

Indians lived at the Hanford Site for thousands of years, until the $1940^{\prime} \mathrm{s}$, when the site was closed for the Manhattan Project. The Hanford Site is on land ceded in treaties with the Yakima Indian Nation and the Confederated Tribes of the Umatilla Indian Reservation. The tribes retain rights and privileges in the ceded areas. They can take fish at all the usual and accustomed places, and hunt, gather roots and berries, and pasture their stock on unclaimed lands.

In November, Congress passed the Native American Graves Protection and Repatriations Act. This law protects Indian burial sites and regulates the removal of human remains and funerary, sacred, or cultural patrimony effects. Other laws protect Indian rights at the Hanford Site and other places. Besides the treaties, other laws protect Indians' culture at the Hanford Site.

- The American Indian Religious Freedom Act protects Indians' rights to believe, express, and exercise their traditional religions, including the right of access to religious sites.

- The Archaeological Resource Protection Act protects archaeological resources on public or Indian lands. That includes criminal penalties for disturbing the remains of Indian activities.

- The Archaeological and Historic Preservation Act preserves significant historic or archaeological data, including relics, that might be destroyed by Federal projects.

- The National Historic Preservation Act.

And many more. Also, a number of State laws and DOE regulations al so protect Indian sites at Hanford.

The Hanford Site is special to the Indians. Because the Hanford Site has been closed to the public since the $1940^{\prime} \mathrm{s}$, it holds a rich store of archaeological sites. Many are undisturbed.

Gable Mountain is viewed as a sacred and religious site to some of the Indians in this area. Gable Mountain is where youths went for the wayikin, or spiritual quest. The individual may meditate for a number of days. They receive guidance for their lives and their people.

The DOE began to consult with affected Indians about Gable Mountain in 1987 , during the repository studies. As a result of consultation with affected tribes during the repository program, we removed the Near-Surface Test Facility and reclaimed the mountain after Congress canceled the repository studies. 
Which Indians?

The Yakima indian Nation has many different bands, or groups. Fourteen bands signed the treaty in 1855. Their reservation is west of the Hanford Site in Toppenish, near the city of Yakima.

The formal name of the Umatilla Indians' government is the Confederated Tribes of the Umatilla Indian Reservation. The tribes are the Umatilla, Cayuse, and Walla Walla.

The Wanapum band still lives in this area. Wanapum means "river people." They live just north of the Hanford Site near the Priest Rapids Dam. In fact, the rapids, now covered by the dam, were named the Priest Rapids because fur traders who observed a Wanapum man performing a religious ceremony thought he looked like a Catholic priest.

The Nez Perce Tribe is annther Hanford neighbor. Their reservation is in Idaho near Lewiston. The Nez Perce used to hunt and fish in this area. They were designated an "affected" tribe during the repository studies. Their ceded lands are east of the Hanford Site.

\section{How Else are Indians Involved at Hanford?}

Tribes are involved in decisions that could affect their treaty rights. Today, the Yakima and the Umitilla Indian governments participate in the Energy Secretary's State and Tribal Government Working Group. This panel reviews DOE-HQ cleanup $\mathrm{pl}$ ans for DOE waste sites. A similar group reviews Hanford-specific cleanup plans. The Nez Perce Tribe is a part of this group. The DOE is providing grant money to the Yakimas and Umatillas (see Section B-11) to be involved in Five-Year Plan activities. A similar grant is being considered for the Nez Perce.

The Yakima Indian Nation is opening an office in Richland for its oversight of Hanford activities. The office will be managed by Robert Cook.

The Umatillas also receive funding to address their concerns about transporting wastes to the Waste Isolation Pilot Plant (see Section B.16).

The Umatilla, Nez Perce, and Yakima Indian governments, along with local, State, and Federal agencies, are consulting with DOE to determine a long-term future site use strategy for the Hanford Site. The DOE and its contractors are working to help tribes prepare their young people to be a part of Hanford's future. The Energy Secretary committed to work with the tribes to develop Hanford cleanup-related training programs for tribal members and support educational efforts for their children. This supports national education goals to increase the number of women and minorities in math, science and engineering fields. Activities that support these goals include job fairs, employment efforts, outreach efforts at tribal educational centers, providing computers for tribal education centers, and establishing programs for cooperative education and affirmative action. 
On the national level, the DOE recognizes the role of the affected Indian governments in the Hanford Site cleanup. On the working level, the key roles need to be defined more specifically.

During the repository studies, three Indian tribes formally participated as "affected tribes." These were the Nez Perce, Umatilla, and Yakima nations. The law guiding those studies provided funding to allow the tribes to participate to protect their interests.

On cultural resource and religious rights and access issues, DOE works with the Umatilla and Yakima nations and also with ths Wanapum tribe.

A member of the Nez Perce Tribe is on the Technical Steering Panel of the Hanford Environmental Dose Reconstruction Project (see Section C.12.1). Eight Indian reservations are located within 200 miles of the Hanford Site. Because their lifestyles are different from those of non-Indians, their uptake of radiation would be different, too. Thus, the researchers have set up coritracts with experts and members of these eight tribes to gather information about their diets and lifestyles so doses can be estimated for those people. The eight tribes are the Yakima, Colville, Kalispel, and Spokane in Washington, the Nez Perce and Coeur d'Alene in Idaho, and the Umatilla and Warm Springs in Oregon.

\section{B.10.2 WASHINGTON STATE'S ROLES AT HANFORD}

Since we have entered a regulatory environment, and most notably since the signing of the Tri-Party Agreement, Ecology has played a significant role at Hanford. Ecology is the regulating agency for RCRA. Ecology represents the state in Tri-Party Agreement matters. Ecology regulates Hanford for nonradioactive air releases. Ecology, however, is not the only Washington agency with a role at the Hanford Site. The State's other participants in Hanford matters are listed below.

The Governor's Office communicates with both DDE-HQ and DOE-RL on policy, funding, and Congressional affairs. The State's involvement in the Western Governors' Association cooperative agreement for activities relating to TRU shipments to the Waste Isolation Pilot Plant is conducted at this level.

The Department of Health regulates the Hanford Site for radioactive air releases. It implements a part of the Federal Clean Air Act. It regulates Hanford's public water system. It is also involved in radiation safety issues and emergency preparedness and response.

The Department of Community Development receives DOE funding to ensure communities are prepared for emergencies. It oversees DOE's environmental monitoring program and gives emergency planning training. These funds also go to the Department of Health and the State Patrol.

A11 Hanford Site contractors participate in the workers compensation program administered by the state's Department of Labor and Industries. 
Washington State has a citizens' panel called the Nuclear Waste Advisory Council, which advises Ecology on the public's concerns about Hanford issues. It has subcommittees on public involvement and transportation.

The State Patrol participates in the Western Governors' Association cooperative agreement in matters relating to transportation safety and emergency response.

Washington's Utilities and Transportation Commission inspects highway route controlled quantity shipments leaving the State and routed through Oregon. (Jregon inspects shipments inbound for the Hanford Site at the Idaho boundary.)

The Energy Facility Siting and Evaluation Council in the Washington State Energy office sites energy facilities. If future facilities were sited at Hanford, that agency would be involved.

Please see Section B.11 for information about DOE funding to Washington State agencies and Section B.16 for information about the State's transportation concerns.

\section{B.10.3 OREGON'S ROLE AT HANFORD}

Oregon has no regulatory role at the Hanford Site. It is, however, downstream and down the road from the Hanford Site. Oregon's support is crucial for cleanup funding. The State and its citizens are concerned about Hanford's past, present, and future impacts on them.

Oregon's main concerns are about the commitment to the 30-year cleanup goal, DOE's sovereign immunity, delays to Tri-Party Agreement milestones, tank safety, funding levels, the national priority systems, and whether Hanford will be considered for new defense activities. Oregon supports TRU waste shipments from Hanford to New Mexico if certain safety and emergency preparedness actions are taken. However, Oregon citizens question whether this is safer than leaving the wastes at Hanford. Oregon is critical that DOE does not provide it and its citizens meaningful opportunities to participate in or influence DOE decisions.

Oregon is on the Energy Secretary's State and Tribal Government Working Group, which reviews DOE's national cleanup plans. Oregon also participates in the Hanford State and Tribal Government Working Group (which includes EPA), which reviews site-specific cleanup plans.

The Oregon Department of Energy takes the lead in the State's involvement at Hanford. Its responsibilities include policy development, Congressional affairs (in close coordination with Washington through the Washington/Oregon liaison on Hanford issues, Jeff Brecke1), cleanup oversight, transportation safety, emergency preparedness and response, and public involvement. The department represents Oregon in Western Governors' Association activities relating to TRU shipments to the Waste Isolation Pilot Plant. Mary Lou Blazek 
represents the State as the vice-chair of the Technical Steering Panel on dose reconstruction.

Oregon's Hanford Waste Board is composed of agency heads and members of the legislature. The board recommends policy to the governor and legislature. The Hanford Advisory Committee is a citizens' panel to advise the board. Members include representatives from public interest groups and local officials on the Interstate-84 corridor who are responsible for transportation safety. The Committee seeks public involvement and focuses on transportation and tank issues. Governor Roberts has introduced legislation to combine the board and advisory committee, reduce its size, and make it more active and influential. It has passed and will become effective this summer.

The Water Resources Department gives technical support on groundwater and tank safety issues.

The Health Division conducts environmental monitoring and supports emergency response management.

Oregon State University gives technical support to the Oregon Department of Energy. It has a contract to do survey research on public opinion on nuclear waste transportation and provide other support for public involvement efforts.

Please see Section B.16 for information about Oregon's transportation concerns. See Section B.11 for information about DOE funding to the Oregon Department of Energy.

\section{B.10.4 COMMUNITY RELATIONS ACTIVITIES IN SUPPORT OF HANFORD CLEANUP}

Federal and State laws call for public involvement in decisions about remedial cleanup and permitting activities. The RCRA, Superfund, and Washington State Hazardous Waste Management Act have provisions for public involvement. For the Hanford Site, DOE-RL, Ecology, and EPA developed a plan for community relations and public involvement in Tri-Party Agreement activities.

The quarterly information meetings mandated by the Tri-Party Agreement were held in April in the Tri-Cities and Yakima. Seventy-eight (down from the usual 100 plus) attended the Tri-Cities meeting and 22 attended the Yakima meeting.

At both meetings, the public had an opportunity to become informed and to comment on EPA's and Ecology's response to DOE's proposal to change several Tri-Party Agreement milestones.

The June meetings focused on Tri-Party Agreement changes and were hosted by the Washington Nuclear Waste Advisory Council. About 240 attended. The council's participation in Tri-Party Agreement meetings is consistent with its efforts to encourage greater public involvement in Hanford cleanup issues. 
The next quarterly meetings will be held in 0ctober.

Meeting dates are announced about three weeks in advance through the Hanford Update newsletter, which is mailed to about 2,300 people. Published quarterly, the Hanford Update has been expanded from four to eight pages to give more in-depth coverage of cleanup issues. The meetings are also announced in news releases and paid newspaper advertisements. Before each meeting, we conduct a media outreach effort to ensure the press is aware of the issues to be discussed. The eight-page quarterly update is published as a joint effort of the three parties. It is one of their primary means to communicate the status of cleanup to the public. In addition, four Hanford information repositories are maintained.

\section{B.10.5 ARMY CORPS OF ENGINEERS ROLE IN HANFORD SITE CLEANUP}

On JuTy 27, 1990, DOE and the U.S. Army Corps of Engineers signed a memorandum of understanding and an Interagency Agreement. The agreement delineates the Corps of Engineers' role in the cleanup of the Hanford Site. It specifically covers the following areas:

- Engineering services

- Cost estimating

- Value engineering

- Technical assistance (including peer reviews)

- Other assistance as needed and mutually agreed to

- Sitewide topographic and geographic survey of monitoring wells and inactive waste sites

- Operable unit assessment activities management

- 1100-EM-1, beginning in FY 1991

- 1100-FR-1 mixed waste operable unit, beginning in FY 1992

- A minimum of one additional operable unit per fiscal year from FY 1992 to FY 1995

- Operable unit cleanup activity management

- 1100-EM-1, beginning in FY 1994

- Other units as assigned

- Additional tasks as mutually agreed to.

Actions in Congress led to the Corps of Engineers' participation in Hanford cleanup. A House Appropriations bill in mid-June 1990 specifically required DOE to use the engineering services of the Walla Walla District of the Corps of Engineers for Hanford cleanup. 


\section{B.11 - FUNDING FOR STATE AND TRIBAL OVERSIGHT}

The DOE funds the States of Washington and Oregon and the Yakima Indian Nation and the Confederated Tribes of the Umatilla Indian Reservation to participate in Hanford Site cleanup activities. Preliminary discussions with the Nez Perce Tribe are under way, but the ultimate level of funding is unknown. The Indian nations are invited to participate in recognition of tribal sovereignty and treaty rights related to ceded 1 ands.

Washington State's grants for FY 1991 RCRA and Superfund oversight total $\$ 5.3$ million, an increase of $\$ 3.8$ million from FY 1990 . The grants reflect a staff increase of 24 full-time equivalents.

Specifics of the FY 1991 grants are as follows.

\section{State of Washington Oversight Funding}

Grant Name: Environmental Oversight (RCRA)

Description: Funding for environmental oversight activities at the Hanford Site in support of DOE activities, including technical analysis, work to be performed under the Tri-Party Agreement, and data sharing on air, soil, vegetation, wildlife, fish, foodstuffs, ambient radiation, and water sampling in the environs of the Hanford Site.

Grantee: Ecology

Amount: $\quad \$ 3,317,358$ - FY 1991

Award Date: December 1, 1990

Grant Name: Environmental Oversight (Superfund)

Description: Funding for environmental oversight activities at the Hanford Site in support of DOE activities, including technical analysis, work to be performed under the Tri-Party Agreement, and data sharing on air, soil, vegetation, wildlife, fish, foodstuffs, ambient radiation, and water sampling in the environs of the Hanford Site.

Grantee: Ecology

Amount: $\quad \$ 2,007,642$ - FY 1991

Award Date: December 1, 1990 
Environmental Monitoring and Emergency Preparedness

Grant Name: Emergency Preparedness and Environmental Monitoring Activities

Description: Provides funding for emergency preparedness activities such as emergency planning, training, hazards assessments. It al so funds environmental radiological monitoring activities such as sampling, analysis, reporting, and oversight of DOE's monitoring program. (These activities are separate from those conducted under the State's Radioactive Air Emissions Program). Funds from this grant are distributed to Washington Department of Health, Washington State Patrol, and Washington Department of Community Development.

Grantee: Washington State Department of Community Development

Amount: $\quad \$ 1,100,000$ - FY 1991

Award Date: January 1, 1991

Yakima Indian Nation Five-Year Plan Funding

Grant Name: Environmental Restoration and Waste Management/Five-Year Plan Program

Description: Provides funding to assist the Yakima Indian Nation with activities related to the Environmental Restoration and Waste Management Five-Year P? an. These activities primarily involve review of DOE plannirg activities to assist DOE in ensuring treaty rights and cultural resources are not impacted as a result of environmental restoration activities being conducted at DOE's Hanford Site.

Grantee: Yakima Indian Nation

Amount: $\quad \$ 728,000$ - FY 1991

Award Date: October 1, 1990

Confederated Tribes of the Umatilla Indian Reservation Five-Year Plan Funding

Grant Name: Environmental Restoration and Waste Management/Five-Year Plan Program

Description: Provides funding to assist the Confederated Tribes of the Umatilla Indian Reservation with activities related to the Environmental Restoration and Waste Management Five-Year Plan. These activities primarily involve review of DOE planning activities to assist DOE in ensuring treaty rights and cultural resources are not impacted as a result of environmental restoration activities being conducted at DOE's Hanford Site. 
Grantee: $\quad$ Confederated Tribes of the Umatilla Indian Reservation

Amount: $\quad \$ 234,733$ (thru 12/31/91)

Award Date: April 9, 1991

The DOE and the Confederated Tribes of the Umatilla Indian Reservation signed a cooperative agreement on May 15 for the Confederated Tribes of the Umatilla Indian Reservation to participate with DOE in the safe transportation of TRU waste from Hanford to the Waste Isolation Pilot Plant. Although no TRU waste shipments from Hanford to the Waste Isolation Pilot Plant are imminent, the cooperative agreement describes activities that DOE and the Umatillas will work on together to erisure safe transportation of TRU waste to the Waste Isolation Pilot Plant site across Indian reservations. The cooperative agreement will:

- Strengthen the Confederated Tribes of the Umatilla Indian Reservation's capabilities where it has regulatory or safety responsibilities

- Increase understanding of the Waste Isolation Pilot Plant transportation activities being undertaken to reduce shipment risk

- To identify and resolve issues of relevance to the Confederated Tribes of the Umatilla Indian Reservation as they relate to TRU waste shipments. The cooperative agreement is for a 5-year period brginning May 15, 1991 and ending December 31, 1996. It will be funded annually, with an initial budget of $\$ 50,000$.

\section{State of Oregon Funding}

Unlike Washington and the Indian Nations, Oregon receives funds through a contract with DOE-RL. This contract began during the civilian repository program and continues to include oversight of the Hanford Site activities, not specifically the repository program.

Under this contract, the State shall perform a 4-year research and development program with respect to the high-level waste (HLW) activities at the Hanford Site and the effects of such activities on the health of the people and environment of Oregon. The contractor will develop and operate a program to provide information to the public about the Hanford Site cleanup and HLW transportation needs and operate a program to disseminate information to the public and key opinion leaders on proposed cleanup, transport, and disposal activities and costs.

The contractor is the Oregon State Department of Energy. The contract is for $\$ 2$ million for 4 years, beginning April 1, 1989, and is limited to $\$ 500,000 /$ year. 


\section{Other Grants to Washington and Oregon}

Although the Tri-Party Agreement is one of the most talked about and best known agreements, it is only one of many agreements by which DOE funds the States. The DOE awards numerous grants to the States for a variety of programs.

The DOE funds programs that include energy conservation, university research, emergency preparedness, and environmental monitoring. The DOE-RL funds these programs throughout Washington, Oregon, Idaho, and Alaska. Some of these grants go to State agencies while others are passed to local communities. Grants range from less than $\$ 100,000$ to almost $\$ 4.0$ million. Some DOE grants require States to contribute a matching amount, while others fund a program in its entirety. 


\section{B. 12 - HANFORD ENVIRONMENTAL IMPACT STATEMENTS}

Several EISs are in the planning and scoping stages at the Hanford Site. They will receive intense public ir.terest and scrutiny. This section gives brief description of pending, planned, and past EISs affecting the Hanford Site.

\section{B.12.1 ENVIRONMENTAL IMPACT STATEMENTS IN PROGRESS}

\section{DOE-HQ Office of Environmental Restoration and Waste Management Programmatic Environmental Impact Statement}

Purpose - This EIS will evaluate the potential environmental impacts, nationwide, of DOE's environmental restoration and waste management program. It will include actions for remediations, compliance with RCRA and Superfund, restoration, waste management, and repositories. Energy Secretary Watkins committed to prepare this EIS in January 1990.

Scoping - The scoping period for this Programmatic EIS began in October and ended February 19, 1991.

Status - The notice of intent was published in the Federal Register in October 1990. Scoping hearings were held in key cities near DOE waste sites from December 3 through December 19 . They resumed on January 7 and continued through February 8. Hearings were held in Portland, Seattle, Richland, and Spokane in December. Because of the holiday season, the comment period was lengthened to 120 days. Comments received here in the Northwest centered on lack of funding for restoration, concerns with the DOE managing restoration work, support for stabilizing waste onsite, opposition to transporting TRU wastes to the Waste Isolation Pilot Plant, and the need for future land use planning at the Hanford Site. The implementation plan is now in development.

DOE-HQ Office of Defense Programs Modernization Programmatic Environmental Impact Statement

Purpose - This Programmatic EIS would assess the potential impacts of the overall restructuring of the DOE defense program and its facilities.

Scoping - The scoping period began on February 11 and will close on September 30, 1991.

Status - On February 11, DOE-HQ announced it will prepare this EIS under a program called "Complex 21." On that day, DOE-HQ also issued an Invitation for Site Proposals soliciting offers of 1 and to be used for building one or more nuclear weapons complex facilities, which would 
operate in the refigured complex. See Section A.15 for information on the Hanford Site response.

In the March 7, 1991 Federal Register, DOE-HQ announced it will hold public scoping meetings in Washington, D.C. and near each of the 13 major sites of the weapons complex, and near any other site identified for the relocation of the weapons complex. Meetings began in Albuquerque on March 20 and will cont inue through August. The meeting near the Hanford Site will be held in Richland on July 31, 1991.

The record of decision is scheduled to be issued in late 1993.

Irradiated Fuels

Environmental Impact Statement

Purpose - This EIS will provide the information needed to decide how to process the irradiated fuel stored at Hanford (see Section C.11). Originally it was planned to reprocess all of this fuel in the PUREX Plant to recover the uranium and plutonium. In October 1990, the DOE Secretary announced a decision to use the National Environmental Policy Act process to determine the disposition of the fuel. This EIS will consider impacts of using PUREX and other alternatives for final disposition of the Hanford irradiated fuel.

Scoping - The tentative date to publish the notice of intent in the Federa7 Register is summer 1991. After the notice of intent is published in the Federal Register, public scoping meetings will be conducted in accordance with the National Environmental Policy Act process.

Status - In mid-October 1990, the DOE Secretary announced this EIS would be prepared. Westinghouse Hanford staff began working to achieve this goal in December 1990. The DOE-RL will select a technical support contractor to prepare the EIS. Westinghouse Hanford is in the process of gathering technical information to support the EIS preparation. It will take 2 or 3 years before the record of decision is issued.

DOE-HQ Office of New Production Reactors

New Production Reactor Capacity Draft

Environmental Impact Statement

Purpose - This draft EIS assesses potential environmental impacts of the proposed action to provide new tritium production capacity, both on a programmatic and site-specific level. Hanford, as well as Savannah River Site and the Idaho National Engineering Laboratory, are evaluated as site locations for the facility. The draft does not name a preferred a) ternative. 
Status - The 45-day comment period closed June 17, 1991. The DOE held 13 public hearings to accept comments on the draft, inciuding hearings in Richland, Spokane, Seattle, and Portland in late May (see Section A.8).

Decommissioning of Eight Surplus Reactors at the Hanford Site, Richland, Washington Draft Environmental Impact Statement

Purpose - This draft EIS assess potential environmental impacts of decommissioning reactors on the Hanford Site. The draft EIS evaluated five different alternatives. Decommissioning of $N$ Reactor is not included within the scope.

Status - The DOE-HQ is very close to authorizing the issuance of the final EIS. See Section B.6.2 for more information.

\section{Comprehensive River Conservation Study/EIS - Hanford Reach of the Columbia River, National Park Service, Draft Environmental Impact Statement}

Purpose - This draft EIS will evaluate options for the future management of the Hanford Reach of the Columbia River. In a 1988 bill, Congress directed the National Park Service to develop and analyze a series of protection alternatives, including designation of the Hanford Reach in the National Wild and Scenic Rivers system.

Status - Analysis of alternatives began last spring. Representatives from more than 40 agencies and groups helped review issues, alternatives, and draft reports. The DOE participated in the study team that leads the efforts. The National Park Service plans to issue the draft EIS in early summer. Public hearings will follow in Richland, Basin City, Yakima, and Seattle. The final report is due to Congress by November 1991 .

\section{B.12.2 PLANNED ENVIRONMENTAL IMPACT STATEMENTS}

Waste Tank Safety Issues

Supplemental Environmental Impact Statement

Purpose - Energy Secretary Watkins announced that a supplement to the HDW-EIS would be prepared to address waste tank management and safety issues. This announcement followed the October 1990 General Accounting Office audit of the single-shell tank program. For this study, a Washington State University professor calculated the impacts of the maximum credible accident in the HDW-EIS, an explosion from ferrocyanide and nitrate in a single-shell tank. The professor concluded the impacts of that accident would be more severe than calculated in the HOW-EIS. 
Scoping - At present the precise scope of this EIS is still undetermined.

Status - Preparation of the formal report will not proceed until DOE-HQ provides direction on the EIS's scope. In the meantime, considerable investigation and sampling work is under way in the tank farms. Information from this work will be used to prepare the EIS. In mid-June Westinghouse Hanford formally recommended combining this EIS with the single-shell tank supplemental EIS, below.

\section{Single-Shell Tanks}

Supplemental Environmental Impact Statement

Purpose - This supplement to the HDW-EIS will evaluate options for disposing of single-shell tank wastes. In the record of decision for the HDW-EIS, we deferred the decision about how to handle the wastes in the single-shell tanks until the tank wastes are characterized and barrier periormance, retrieval, processing, and disposal performance were evaluated.

Scoping - To be determined.

Status - A Tri-Party Agreement milestone calls for closure of the singleshell tanks by 2018. This schedule causes concerns, which may require preparation of this supplemental EIS sooner than originally planed. We may publish a notice of intent in late 1992, and complete the EIS

by 1996. In mid-June Westinghouse Hanford formally recommended combining this EIS with waste tank safety issues supplemental EIS, above.

\section{Hanford Remedial Action}

\section{Environmental Impact Statement}

Purpose - If approved, this EIS would assess the potential impacts of remediation alternatives at the Hanford Site. This EIS would place major emphasis on cumulative impacts. We will still prepare specific National Environmental Policy Act documentation as needed for specific remediation of individual operable units. This EIS would be examined every 5 years to ensure it sufficiently documents impacts from actual remediation activities.

While the HDW-EIS covered disposal of double- and single-shell tank wastes and TRU wastes, and the Surplus Production Reactor Decommissioning EIS covered disposal of the eight production reactors and related facilities, an EIS is still needed to address environmental restoration and management of the liquid effluent disposal sites and buried solid low-level wastes.

Scoping - Assuming DOE-HQ approval in summer 1991, the scoping period would begin the following fall or winter. 
Status - The DOE-RL submitted an Action Description Memorandum to DOE-HQ for review and approval. The DOE-RL recommended that an EIS is required to evaluate cumulative impacts of remedial action alternatives. A decision is expected from DOE-HQ in summer 1991.

Hanford Sitewide

Environmental Impact Statement

Purpose - As part of his 10-point initiatives in June 1989, the Energy Secretary mandated an EIS for each DOE facility. This EIS will document the overall operations and activities at the Hanford Site. It will serve as an integrative document to identify the completeness of National Environmental Policy Act documentation and to forecast additional documentation requirements.

Scoping - To be determined.

Status - Action has yet to be initiated for this EIS.

\section{B.12.3 PAST ENVIRONMENTAL IMPACT STATEMENTS THAT AFFECT THE HANFORD SITE}

- ERDA-1538, Final Environmental Impact Statement--Waste Management Operations, Richland, Washington, December 1975. This EIS presented the impacts and alternatives available for the Hanford Waste Management Operations Program. A record of decision was never issued for this EIS, however, a record of decision was issued for the supplemental EIS (see DOE/EIS-0063).

- DOE/EIS-0026, Final Environmental Impact Statement--Waste Isolation Pilot Plant, October 1980. It was proposed to construct a Waste Isolation Pilot Plant to provide a research and development facility to demonstrate the safe disposal of TRU wastes resulting from the defense activities and programs of the United States. This EIS considered sites, including Hanford, in various regions and media. It did not, however, address Hanford's TRU wastes. The record of decision, 46 FR 9126, was issued January 28, 1981.

- DOE/EIS-0026-FS, Final Supplement Environmental Impact Statement-Waste Isolation Pilot Plant, January 1990. This supplement evaluated the environmental impacts associated with new information and changes in the proposed action since the record of decision was issued in the final Waste Isolation Pilot Plant EIS. It covered Hanford's TRU waste and the transportation of that waste to New Mexico. The record of decision, 55 FR 25689, was issued June 13, 1990. 
- DOE/EIS-0063, Supplement to ERDA-1538, Final Environmental Impact Statement, Double-She 71 Tanks for Defense High-Level Radioactive Waste Storage at the Hanford Site, April 1980. This EIS evaluated the environmental impacts of the construction and operation of 13 tanks for high-level radioactive liquid waste storage on an interim basis until long-term or final disposal of the wastes could be achieved. The record of decision, 45 FR 46155, was issued July 1980.

- DOE/EIS-0080, Final Environmental Impact State--Decommissioning of the Shippingport Atomic Power Station, May 1982. This EIS evaluated the environmental impacts of the decommissioning of the Shippingport Atomic Power Station located on the Ohis River at Shippingport, Pennsylvania. The preferred alternative proposed to immediately dismantle and remove all fluids, piping, Eijuipment, components, structures, and wastes to a waste disposal area. The Hanford Site and Savannah River Site were chosen as possible disposal areas. The Hanford Site has received the reactor vesSEl. The record of decision, 47 FR 36276, was issued August 1982.

- DOE/EIS-0089, Addendum to Environmental Impact Statement-. Operation of PUREX and Uranium Oxide Plant Facilities, Hanford Site, Richland, Washington, February 1983. This addendum and the draft EIS (DOE/EIS-0089D) constitute the final EIS. It was proposed to resume the operation of the PUREX/UO $\mathrm{O}_{3}$ facilities. Operations did indeed resume. The record of decision, 48 FR 21993, was issued May 1983.

- DOE/EIS-0113, Final Environmental Impact Statement--Disposal of Hanford Defense High-Level, Transuranic and Tank Wastes, Hanford Site, Richland, Washington, December 1987. This report, commonly referred to as the HDW-EIS, examined the potential impacts calculated for alternatives for the final disposal of existing defense wastes stored at the Hanford Site since 1943 and future wastes (those produced after October 1983). On the basis of this report, the DOE decided to pretreat existing and future double-shell tank wastes, vitrify the high-level fractions for onsite burial, continue to store the cesium and strontium capsules for ultimate disposal in a geologic repository, and build the Waste Receiving and Prucessing (WRAP) facility to prepare the newly generated and retrievable stored TRU wastes for disposal offsite. Decisions were deferred about single-shell tank wastes, TRU-contaminated soils, and pre-1970 buried suspect TRU-contaminated solid wastes in the 200 Area plateau. The record of decision, 53 FR 12499, was issued April 1988. 
- Final Environmental Impact Statement on the Disposal of Decommissioned, Defueled Naval Submarine Reactor Plants, U.S. Navy, Washington D.C., May 1984. This EIS identified and evaluated alternatives to allow an informed decision on how to dispose of the defueled reactor compartments. It considered seabed as well as 1 and disposal. The record of decision was issued in 1984. It called for 1 and disposal, with the Hanford Site being used in the near future since most of the submarines are being decommissioned on the West coast of the United States. 


\section{B.13 - WASTE MINIMIZATION GOALS AND STATUS}

\section{B.13.1 PROGRAM OBJECTIVES AND SCOPE}

Westinghouse Hanford's Wi jte Minimization Program was designed to meet DOE Orders 5400.1 and 5820.2A, and DOE-HQ guidance, which is consistent with EPA guidelines. The major elements of the program are:

- Top management support

- Employee training, awareness, and incentives

- Program scope, objectives, goals

- Waste minimization assessments/audits

- Accurate cost accounting

- Accurate waste accounting

- Technology transfer

- Program evaluation.

The program focuses on preventing the generation of waste. It also implements a strategy to reduce the volume and toxicity of waste that are nevertheless generated. In order of priority, the program advocates waste generation prevention using source reduction and rec $^{\prime} \mathrm{cl}^{\mathrm{ing}}$ techniques, treatment, and finally disposal of wastes. Wastes targeted for minimization include radioactive (high-level, TRU, low-level), radioactive mixed, hazardous, and non-RCRA regulated wastes.

Each Westinghouse Hanford facility that generates, treats, stores, or disposes of hazardous, radioactive, or mixed waste has prepared a facilityspecific waste minimization plan. The plan focuses on a facility's specific waste. Each individual wastestream will be identified and characterized with respect to origin, composition, quantity generated, cost, environmental and safety impacts and waste minimization potential. The plans provide a vehicle for setting annual waste minimization goals and provide a trackable system for documenting waste minimization achievements.

The Hazardous Waste Reduction Act passed by the Washington State Legislature requires a more in-depth evaluation of wastestreams than currently exists. In addition, DOE has required all facilities to perform Process Waste Assessments which closely parallel the State requirements. The Pollution Prevention Act of 1990 mandates additional requirements for documenting waste minimization efforts. Westinghouse Hanford and DOE-RL are in the process of evaluating the impact of these new requirements on the Waste Minimization Program.

\section{B.13.2 ACCOMPLISHMENTS}

The 1990 Annual Waste Reduction report was completed March 31, 1991 and submitted to DOE-HQ. In 1990, approximately $5,906,000 \mathrm{~kg}$ of waste were avoided using waste minimization techniques, for an estimated $\$ 633,000$ cost savings. The actuai cost savings from avoided disposal, including avoided 
liability costs, are difficult to determine because final treatment and disposal methods for most waste have yet to be finalized.

Many of the waste minimization successes in 1990 resulted from finding users 'or excess chemicals using onsite contacts via the Surplus Chemical Exchangt or informal channels. Approximately $2,700 \mathrm{~kg}$ of waste were avoided across the Hanford Site through exchanges directly related to the Surplus Chemical Exchange. The sorting table at $100-\mathrm{N}$, initially designed to sort radioactive waste for compaction, was siccessful in recovering numerous reusable items such as masks, boots, gloves, and overalls, saving approximately $\$ 15,000$ in purchasing costs in 1990.

Waste minimization techniques are also an improvement to the health and safety of workers. Identifying and using less hazardous materials to perform an activity reduces the hazard of the operation. Several Hanford facilities have successfully substituted less hazardous materials in their activities.

Waste minimization efforts were successful in allowing the continued operation of Hanford Site facilities while working to restart the evaporator. Task teams were established at each plant to evaluate the minimization potential for each radioactive liquid wastestream. The task teams established maximum waste generation limits at each plant. In addition, a multifunction Tank Space Management Board consisting of plant managers was established to review efforts to reduce wastes generated and to exceed established volumes. The volume of liquid waste avoided through waste reduction efforts to date exceeds 11 million liters.

A paper recycling program has expanded to include several Westinghouse Hanford buildings both in town and on the site. Since January 1991, approximately 56,000 $1 \mathrm{~b}$ of paper have been recycled. 


\section{B.14 - LAND, AIR, AND WATER CONTROL AT HANFORD}

The Hanford Site is about $1,450 \mathrm{~km}^{2}\left(560 \mathrm{mi}^{2}\right)$, roughly half the size of Rhode Island (Figure B-11). Parts of its borders are marked by fences and parts by the Columbia River. About 10 percent of Hanford Site lands are used for its nuclear and energy missions. This section discusses specials uses and control of Hanford Site Iand, air, and water.

\section{B.14.1 LAND}

The western part of the Hanford Site has been designated as an Arid Lands Ecology Reserve. The area is managed for the DOE-RL by PNL. Its boundaries are the crest of Rattlesnake Ridge to the west, Highway 240 to the east, and Highway 24 to the north. The Arid Lands Ecology Reserve is a (124 $\mathrm{mi}^{2}$ ) outdoor laboratory for ecological research. It is the last remaining expanse of shrub-steppe ecology in the United States. The area has been a reserve formally for more than 25 years and has been undisturbed by human development for almost 50 years. Scientists at PNL study it in its pristine state. Access there is limited for scientific purposes.

North and east of the Columbia River is an area called the Wahluke 5lope. The DOE issued a permit to the U.S. Fish and Wildlife Service and Washington State Department of Game (now the Washington State Department of Wildlife) for this use of the land in 1975. It is about $489 \mathrm{~km}^{2}\left(189 \mathrm{mi}^{2}\right)$. The portion permitted to the U.S. Fish and Wildlife Service has no public access and is used for a wildlife preserve. Portions of the Saddle Mountain National Wildlife Refuge are on Hanford Site land. The portion permitted to the Washington State Department of Wildlife is open to public access as a recreation area during daylight hours. The State rents some of it to ranchers to graze their cattle, too.

The area is remote and has never been used for Hanford nuclear operations. It is not pristine, however. Wind carried airborne releases from the production reactors to this area in Hanford's earlier years. After the government acquired the area in 1943, it used the Wahluke Slope as a buffer zone and at times as a base for military defense of the Hanford Site until 1975. It had seven antiaircraft batteries. These were replaced in the 1950's with three NIKE missile sites. The U.S. Army managed those sites.

An investigation that began in December 1989 has found hazardous waste in old garbage dumps. One dump found was a polychlorinated biphenyl (PCB) disposal site the Bureau of Reclamation established. Another had soil contaminated with a pesticide. Others had materials such as empty oil cans. The DOE is evaluating options for cleaning up these sites.

Near the northwest corner of the Hanford Site is the Midway substation. The Bonneville Power Administration has owned the land at Midway since before the Hanford Site's establishment. When the DOE was formed in 1977, it took 
Figure B-11. Hanford Site Land Use.

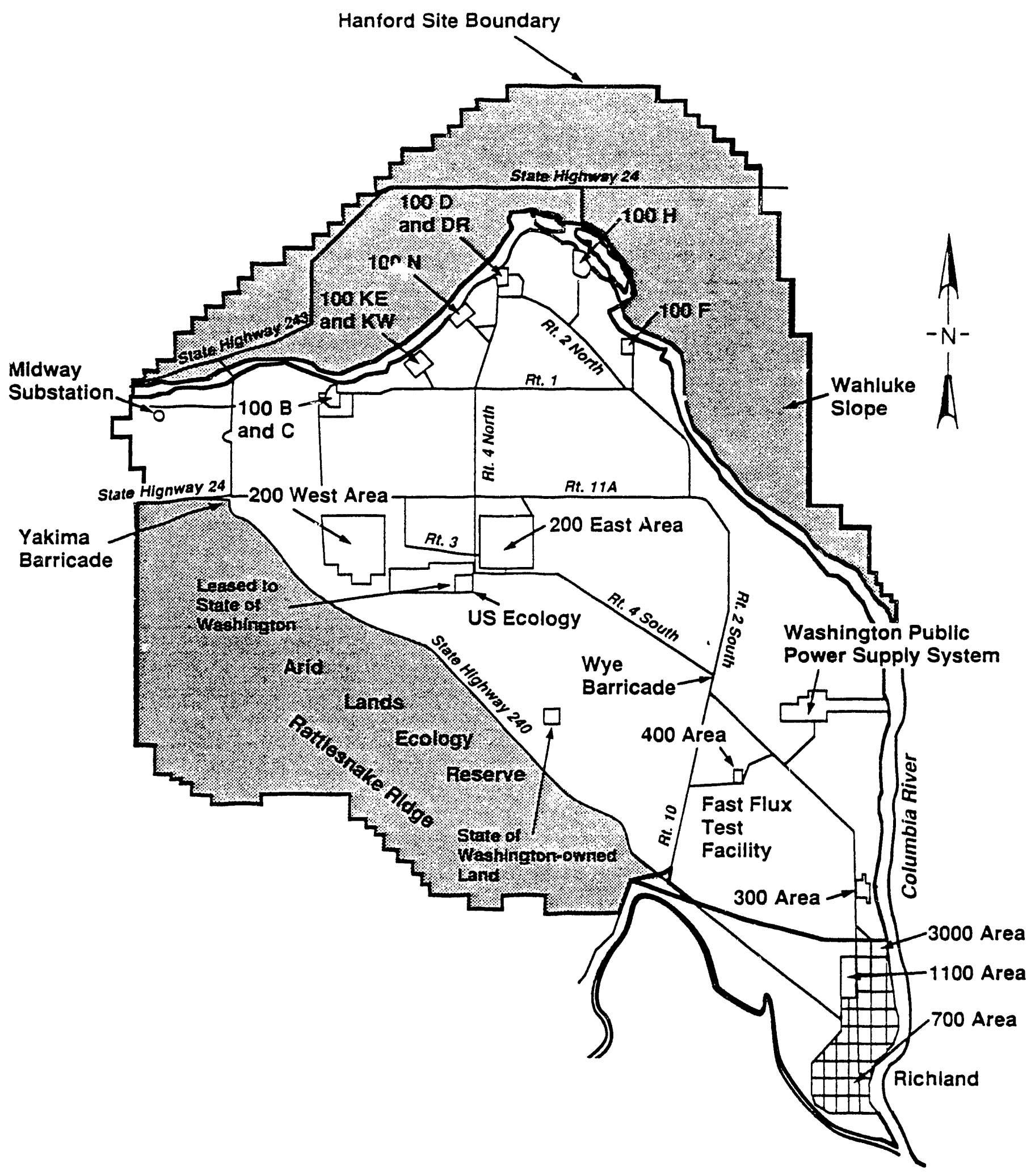


over the Bonneville Power Administration. It al so took over the Atomic Energy Commission, which became the Energy Research and Development Administration. So, while the Midway substation is a part of DOE and Hanford, it is not a part of DOE-RL. It is funded differently, too.

The Midway substation is about 21 ha (52 acres). Until about 5 years ago, there was a small community there where substation workers lived. Its average population was 55. It was self-supporting, and even had a school. The last resident left in 1987, when Bonneville Power Administration mechanized the substation. The DOE-RL considered but declined to buy that land for the Hanford Site.

At present the General Services Administration is selling as a block 20 of the houses from the Midway community. Occasionally neighbors' horses drift onto the land. The DOE periodically contacts those neighbors to ask them to retrieve their horses. Today, fishermen use the land. They have access from a road off Highway 240 the county used to maintain.

The Bonneville Power Administration has a use permit from DOE-RL for the H. J. Ashe Substation. This substation is about 8.5 ha ( 21 acres), about a quarter mile north of the Washington Public Power Supply System WNP-2 Reactor.

The rest station on Highway 240 near the Vernita Bridge is on land permitted to Washington State Department of Transportation. The state established the rest station in the early 1970's; after Highway 240 was opened for public use.

The DOE issues four yearly permits to allow access to Rattlesnake mountain. There are transmission towers there for ham radios and cellular telephones. Three of the permits are to commercial companies, and one is to the Tri-City Amateur Radio Club.

The DOE leases 1,000 acres between the 200 East and 200 West areas to the State of Washington. It is a 99 -year lease through the year 2060 . The state's agency, Ecology, then subleases 100 acres of that 1 and to U.S. Ecology. This private company operates a commercial low-level waste disposal site.

The DOE has leased 834 ha $(2,061$ acres $)$ to the Washington Public Power Supply System for the construction and operation of its commercial nuclear reactors. It is a 99-year lease that expires in 2065.

The State of Washington also owns outright 97 ha (240 acres) in the middle of the Hanford Site. The state's land is off Highway 240, opposite the Arid Lands Ecology Reserve. It is not marked, and the state does nothing with it. The DOE sold this 1 and in 1978. The deed states the land can only be used for a hazardous materials disposal site. At that time the national plan was for each state to have its own site for this use. In practice today, the state sends its hazardous waste to a disposal site in Arlington, Oregon.

A few years ago the official estimate of the size of the Hanford Site changed from $1,476 \mathrm{~km}^{2}\left(570 \mathrm{mi}^{2}\right)$ to $1,450 \mathrm{~km}^{2}\left(560 \mathrm{mi}_{2}\right)$. This stemmed from a 
reassessment that began in 1984 to account for the lands that the DOE had sold over the years. The official size is $1455.5 \mathrm{~km}^{2}\left(562 \mathrm{mi}^{2}\right)$. Initially the Hanford Site encompassed $1,657^{2}\left(640 \mathrm{mi}^{2}\right)$, including the city of Richland, the Yakima River delta, and more land south and north of the site's present boundaries.

\section{B.14.2 AIR}

Airspace over most of the Hanford Site is called a "National Security Area." This places no restrictions on pilots aside from the restrictions that apply anywhere else. So pilots must stay more than 1,000 feet above ground level over areas with buildings. Notices on navigation charts state, "Notice: for reasons of national security, pilots are requested to avoid flight below 2,400 ft mean sea level."

The National Security Area covers the Hanford Site from the 300 Area on the south, upriver to a few miles upriver from the Vernita Bridge, south to Highway 240 to the Horn Rapids substation, then back to the 300 Area. In other words, it covers all but the very southern tip of the Hanford Site. Airspace has been managed this way since 1975 .

When the Hanford Site was established, airspace was prohibited from ground up for the whole former $1,657 \mathrm{~km}^{2}\left(640 \mathrm{mi}^{2}\right)$. Airspace changed from prohibited to restricted in the early 1960 's. Pilots could fly over the Hanford Site if they were above $10,000 \mathrm{ft}$ mean sea level. This change was partly in response to aviation interests.

\section{B.14.3 WATER}

The DOE owns Hanford land down to the high water mark of the Columbia. The Army Corps of Engineers owns the rest. The public has access to Army Corps of Engineers lands. The State owns the riverbed itself. The Army Corps of Engineers controls most islands. The DOE owns three: Locke (near $100 \mathrm{D}$ Area), Savage (opposite $100 \mathrm{~F}$ Area), and Wooded (near the 300 Area). These islands are nearest the original facilities for plutonium production.

Islands the DOE owns are posted but not fenced. State and Federal laws protect the cultural and natural resources on all the islands. Those islands provide nesting and spawning habitat for birds and fishes. 


\section{B.15 - TIGER TEAM ASSESSHENT ACTION PLAN}

Hanford Site personnel submitted the Preliminary Action Plan to DOE-HQ ahead of schedule on April 10. This action plan, if approved by the Secretary of Energy, will represent the Hanford Site's response and planned actions to the Tiger Team Assessment. Since the first action was submitted on January 30, 1991, much work was done in revising the action plan to incorporate DOE-HQ's comments. The comments focused on our integration and commitments to the planned actions, and how the site would assure corrective action implementation. The DOE-HQ provided comments to 228 of the 371 responses and planned actions with the expectation to revise and incorporate comments to the introductory material as well.

The DOE-HQ comment disposition and resolution process went well, thus enabling the site to continue with the planned actions that had been established in August and September 1990. On the whole, DOE-HQ thought the action plans would resolve the findings and mainly commented for clarity and schedule improvements. This review and approval process is lengthy but has not inhibited the schedule of our planned actions.

The DOE-RL and all contractors are maintaining a database to track these actions with the first sitewide status update expected by June 30,1991 . Following approval of the Action Plan, all planned actions will be tracked to closeout. Closure of planned actions will be performed by DOE-RL on a graded basis depending on the severity of the Tiger Team Finding.

The cost estimates and schedules through FY 1991 have been established consistent with requested funding levels for the site. Resource estimates for planned actions which require funding under the DOE-HQ Environmental Restoration and Waste Management program are consistent with the Requirements Case in the Five-Year Plan.

The message from DOE-HQ was that it was looking for visible signs of improvement (i.e., culture change, communications, morale, and utilization of resources). The Hanford Site is committed to these changes. One major area of focus is in the self-assessment process. We are committed to performing future self-assessments to evaluate the long-term adequacy of corrective actions in resolving the Tiger Team findings.

Management attention and commitment are also required to ensure that appropriate and prompt changes are made. Steps must be taken to ensure:

- The degree of formality and rigor of Environment, Safety, and Health activities at the Hanford Site are at an acceptable level when compared to the commercial nuclear industry

- The desired Environmental, Safety and Health culture change is being achieved at all levels

- Resources are efficiently used 
- The internal Environment, Safety and Health review process, including independent oversight, self assessment, and corrective action, is appropriate

- The integration and prioritization of Environment, Safety and Health activities is adequate.

A Hanford root cause evaluation team was formed to further evaluate root causes. This team focused on root cause/causal factors of the Tiger Team's key findings. Planned actions include mejor sitewide initiatives structured to improve conduct of operations. The actions will bring the Hanford Site into compliance with all applicable laws and regulations. They will establish of implementing programs to ensure that senior and middle management are frequently present in the field to personally assess safety-related performance as well as operations, housekeeping, and facility conditions. The actions will, most importantly, set up a new system for ranking and tracking issues and a new facility performance indicator program with further c?pabilities.

These activities, along with specific planned actions, should not only correct specific findings and concerns identified by the Tiger Team Assessment, but should also correct root causes that may be impacting operations sitewide. 


\section{B.16 - ATOMIC ENERGY ACT - RESOURCE CONSERVATION AND RECOVERY ACT INCONSISTENCIES}

Inconsistencies between the Atomic Energy Act and RCRA cause challenges in complying with environmental regulations. This question faces the DOE complex nationwide. Some of the issues concern circumstances in which it is unclear how both RCRA and the Atomic Energy Act requirements should be jointly implemented. Other issues are about the potential applicability of RCRA to the management of certain nuclear materials. In many cases, the Atomic Energy Act's requirements to conduct activities to keep doses as low as reasonably achievable conflict with requirements of RCRA. Hanford Site wastes present a number of these challenges.

Examples:

- Representative sampling of nonhomogeneous waste forms. Representative sampling of nonhomogeneous waste forms to meet RCRA standard testing methodologies is difficult. The use of process knowledge in determining that a waste is not hazardous is often not enough to satisfy regulations.

- Compliance with RCRA land disposal restrictions. Compliance with certain provisions of the RCRA land disposal restrictions program is now impossible for DúE mixed waste streams, particularly those provisions involving storage of land disposal restricted waste.

- Near-term compliance with RCRA technical standards. Due to the llazard!; imposed by the radioactivity associated with certain mixed wastes, strict adherence to some RCRA technical standards may not be achievable in the near term.

- Scrap or excess lead. Does RCRA apply to the storage of radioactively contaminated lead for the purpose of future use?

- Scrap and residue. Does RCRA apply to the management of materials that are scrap or residues, which contain valuable source or special nuclear materials that can be reclaimed, recycled, or recovered?

In January 1990, Westinghouse Electric Corporation and the Savannah River Operations Office sent letters to DOE-HQ outlining compliance issues affecting DOE sites that Westinghouse operates. The DOE then formed a task force with representatives from affected sites to develop or clarify an appropriate interpretation on these issues. The work group has developed draft DOE position papers and proposed strategies. These issue papers are being circulated to DOE field and program offices and the DOE's Office of General counsel for review and comment. After the DOE's understanding of these issues is clarified internally, DOE intends to begin discussions with EPA and/or the U.S. Nuclear Regulatory Commission (NRC) on certain issues, as appropriate. 
At Hanford, DOE has notified its reguiators of the compliance issues we consider unresolved and of national significance. Ecology has not formally responded. The EPA is addressing this issue on the national level. 


\section{B.17 - TRANSPORTATION CONCERNS}

Transportation issues and concerns are important to the public and their representatives, including those from Washington, Oregon, the Yakima Indian Nation, and the Confederated Tribes of the Umatilla Indian Reservation. State and tribal involvement in radioactive materials transportation has been noteworthy in the following areas:

- DOE-HQ Transportation Assessment and Integration workshop

- Cesium shipments returning from Denver, Colorado

- Western Governors Association/DOE Risk Communications training

- Waste Isolation Pilot PIant shipments and cooperative agreements

- Request for onsite inspections of highway route controlled quantities and shipment data

A separate transportation issue of high visibility and interest is the onsite shipping guidance from DOE-HQ.

The DOE-HQ Transportation Management Program (EM-50.1) is evaluating its organization and program to determine what actions are necessary to ensure that it is responsive to transportation and packaging needs in the $1990^{\prime} \mathrm{s}$. This effort was undertaken to evaluate recent important changes in DOE organization, policies, and management philosophy. The Transportation Assessment and Integration Project will explore how to better support the transportation program and field offices as well as coordinate with the Environmental Restoration and Waste Management Five-Year Plan and community relations activities associated with environmental restoration and cleanup. The assessment has been split into eight issue areas. Two Westinghouse Hanford managers have been assigned lead principal investigator positions. They are to conduct the assessment and prepare the recommendation for training and institutional and outreach programs. Westinghouse Hanford hosted a large workshop in St. Louis, Missouri, May 20-23 to gather information about needs and concerris of vested parties in DOE transportation. Representatives from Washington, Oregon, and Confederated Tribes of the Umatilla Indian Reservation participated in the workshop.

The States of Colorado, Oregon, Washington, Idaho, and Wyoming have expressed strong interest and need for involvement on planned cesium shipments from the Denver IOTECH facility to Hanford. About 35 shipments are planned to begin later in 1991 and run until December 1992. A joint meeting was held on April 24, 1991 in Colorado with concerned State agencies and DOE-HQ, DOE-RL and Westinghouse Hanford. Washington and Oregon are requesting that DOE consider using the Waste Isolation Pilot Plant transport safety program on an incremental basis for these shipments.

The States of Oregon and Washington continue to press for early shipments of TRU waste to the Waste Isolation Pilot Plant. A Congressional directive 
that Hanford shipments be included in the Waste Isolation Pilot Plant test phase was incorporated into the Energy and Water Development Appropriations Bill. The Waste Isolation Pilot Plant Project office has entered into a cooperative agreement with 10 western corridor states, including Washington and Oregon, through the Western Governors' Association. The purpose of the agreement is to address transportation concerns identified by the states, including accident prevention, emergency preparedness and public information. Each State submits its plans to the Waste Isolation Pilot Plant Project office for review and approval. The Oregon and Washington work $\mathrm{pl}$ ans have been approved for funding in all areas for a total of $\$ 150,000$ each.

The DOE also is entering into cooperative agreements with tribal governments along the Waste Isolation Pilot Plant shipment routes. These agreements will be jointly administered by Waste Isolation Pilot Plant and the DOE field offices. In this regard, DOE-Waste Isolation Pilot Plant and DOE-RL signed an agreement May 15, 1991 with the Confederated Tribes of the Umatilla Indian Reservation for a total funding of $\$ 50,000$.

Oregon requested that $D O E-R L$ al low the state to inspect highway route controlled quantity shipments at the Hanford Site before departure. Oregon law requires all highway route controlled quantity shipments be inspected upon entering Oregon. Oregon has entered into an agreement with the Washington Utilities and Transportation Commission to allow Washington to conduct those inspections at the Hanford Site, which is close to the State line. Oregon is concerned that, if there is a problem, corrective measures should be conducted at the Hanford Site before the shipment leaves. In response to this request, Westinghouse Hanford is arranging for the inspections with the Washington Utilities and Transportation Commission before the shipment leaves. This approach worked well several years ago for outgoing cesium shipments. Oregon has also requested a written summary every 6 months of all placard shipments leaving Hanford. Westinghouse Hanford has provided this information to DOE-RL for transmittal to Oregon.

The DOE-HQ provided guidance that requires shipments of hazardous materials transported on, across or along public access roads that traverse the Hanford Site meet U.S. Department of Transportatic regulations. As a result all hazardous materials shipments south of the Wye Barricade on Route $4 S$ or Route 10 are considered to be offsite shipments and require compliance with the U.S. Department of Transportation regulations. Additional guidance is expected to declare DOE site roads south of the Wye Barricade as "public" and subject to U.S. Department of Transportation regulations, but permit temporary barricading as an alternative to full U.S. Department of Transportation compliance. The DOE-RL and Westinghouse Hanford Transportation and Packaging have actively supported and assisted DOE-HQ in the development of the onsite guidance document. Westinghouse Hanford's Transportation and Packaging has issued letters to the operating facilities outlining the new policy and the anticipated changes in handling hazardous material shipments. 
The Western Governor's Association work group on TRU shipments and the DOE-HQ Transportation Management Program co-hosted a risk communications workshop April 18-19 in Salt Lake City. Westinghouse Hanford, in collaboration with Bob Robison of Oregon, planned and facilitated the workshop.

Robison is the chairman of the Western Governors' Association work group. The workshop focused on the risk communications principles and public involvement. The states requested that DOE support the meeting with transportation and public affairs representatives from DOE sites in Colorado, Idaho, and Richland. This effort was very well received by the states. 


\section{B. 18 - THE COLUMBIA RIVER'S HANFORD REACH}

Decisions today will determine the future of the Hanford Reach of the Columbia River. A congressionally mandated study is selecting a preferred alternative for the protection of the last free-flowing section of the Columbia River.

Congress passed a law in 1988 for a comprehensive study of the Hanford Reach. The act called for the National Park Service to take a couple of actions. One was to inventory and evaluate the river's resources. The Park Service completed this in April 1990. Another was to develop and analyze a series of protection alternatives, including designation of the section in the National Wild and Scenic Rivers system. The law requires the Park Service to complete its study and present it to Congress by November 1991, 3 years from the date the law was passed.

\section{How was the Study Conducted?}

The National Park Service has the lead in the study. Officials from the Park Service, the DOE, and the U.S. Fish and Wildlife Service direct the study overall and do most of the day-to-day work.

A task force advised the study team. Representatives from more than 40 agencies and groups helped review the issues, alternatives, and draft reports. The task force represented a wide cross-section of interests in the river. Members included private landowners on the Reach, environmental groups, Benton and Franklin County commissioners, the U.S. Fish and Wildlife Service, the National Park Service, other State and Federal agencies, and the DOE.

\section{What are the Alternatives?}

Options range from no action to a wild and Scenic River. Which State or Federal agencies would manage the area, whether development would be limited, and how far from the shore the protection would extend, among others, are to be determined.

Analysis of the alternatives began in May. The 1 aw creating the study calls for consideration of the option of designating all or parts of the river into the Wild and Scenic Rivers Program.

Debate over the options has been lively. Understandably, many study participants have competing interests.

\section{What is the Status Now?}

The Park Service will announce its preferred alternative in a draft EIS to be issued in the early summer (see Section B.12.1). A public comment 
period will follow. Public hearings are will be held in Richland, Basin City, Yakima, and Seattle. The record of decision, due to Congress in November, will present the study team's final recommendation.

\section{What is the Study's Impact on Hanford?}

Impacts today are limited. Basically, we must coordinate and consult on any activity that might affect the values for which the river is being studied. The law states that for 8 years after its enactment (in 1988), no Federal agency may build any dams, or navigation or channelization projects. It also requires all other activities, to the extent practicable, to be planned and implemented to minimize adverse impacts on the river's resources. The law lays out a procedure for conducting activities that affect the river. See Section C.15 for discussion of how Hanford Site activities are conducted in this new regulatory context.

Future impacts are hard to describe today. It's reasonable to believe that after November 1991, some of the Hanford Reach will be protected. The degree of protection and width of the protected corridor remain to be determined, but it's unlikely a no action option would result. The future impacts could be great if a protective zone is established along the river. For example, it could preclude stabilizing any waste sites along the river. Instead, they might have to be relocated. That's why this study is an important part of our future site use strategy. 


\section{B.19 - TECHNOLOGY NEEDS FOR ENVIRONMENTAL RESTORATION}

Success in cleanup hinges on four key ingredients: qualified workers, adequate funds, public and political support, and successful technologies. Some of these technologies are yet to be developed. The need to find better, smarter, faster, and cheaper ways to clean up Hanford is clearly recognized.

Technology support to waste management is focused primarily in the areas of characterization, minimization, treatment, storage, and disposal for tank wastes and solid wastes. For environmental restoration, efforts center on characterization, risk and performance assessment, and remediation of old waste sites.

In a joint effort, PNL and Westinghouse Hanford have developed a list of the main technology needs for the Hanford Site Environmental Restoration Remedial Action Program. That list is presented below.

- Predictive capabilities to develop and evaluate alternative remediation methods

- Hydraulic barrier modeling

- Remedial Action Assessment system

- Groundwater flow and contaminant transport under variably saturated conditions

- Multiphase, multifluid flow, and transport analyses

- Improved techniques for sensitivity and uncertainty analyses

- Improved analytical methods for hazardous and radioactive materials

- Improved methods for hazardous waste site monitoring

- Mobile laboratories

- Low cost field analytical screening techniques

- Real time analytical techniques for treatment equipment process control

- Improved sample turn around times

- Automated fixed laboratory analysis processes

- In situ isolation using surface and subsurface barriers to contaminant migration

- Long-term permanent isolation barriers and warning marker systems

- Slurry walls

- In situ vitrification barriers

- Sorbent barriers

- Cryogenic barriers

- Grout curtains

- Chemical adders

- Tank dome filling

- Waste retrieval from tanks and underground structures 
- Robotic articulated arms and other mechanical methods

- Hydraulic sluicing

- Radiation hardened equipment with remote sensing and control

- Sluice barriers

- Waste transfer systems

- In situ characterization of wastes

- In situ monitoring of vadose zone and groundwater and geohydrologic properties

- Improved void detection techniques and geophysical surveying techniques

- Portable/miniaturized gas chromatographs, mass spectrometers, and sample preparation equipment

- Multi-wavelength spectral imaging

- High resolution spectral gamma detection, neutron activation, and others

- Improved partitioning methods

- Segregation of mixed wastes into hazardous chemicals and radionuclides

- Selective removal of target waste species

- Solids dissolution

- Clarification centrifuge

- Strontium, TRU, and cesium extraction

- Technetium removal

- Molecular recognition

- Complexant destruction

- Improved groundwater treatment methods

- Bioremediation

- Thermochemical conversion

- Enhanced contaminant extraction

- In situ treatment of wastes

- In situ precipitation techniques for gases and chemicals

- Bioremediation

- In situ vitrification

- In situ heating

- In situ grouting

- In situ drying of tanked wastes

- Offgas collection and treatment

- Polyethylene encapsulation

- HLW glass formulation

- Denitration

- Waste form assessment to evaluate reduction in mobility, toxicity, and leachability

- Leachrate validation 
- Improved soil treatment methods

- Transportable soil washing equipment

- Bioremediation

- Vitrification

- In situ heating

- Grouting

- Vapor extraction

- Soil flushing/solution mining

- Improved waste forms to reduce mobility, toxicity, and leachability

- Grout

- Glass

- Polyethylene encapsulation

- Treatment of mixed wastes

- Real time analytical techniques for cleanup equipment process control

- Mobile incineration equipment

- Mixed waste segregation into hazardous chemical and radionuclide components

- In place treatment of residual wastes after retrieval

- Robotics to decrease exposure, improve drilling efficiency, reduce number of support personnel

- Soil gas monitoring in coarse geologic media

- Improved organic destruction methods

- Contamination control during waste retrieval, sampling, and remediation

- Foams and fixants

- Bulk waste transport techniques

- Transportable containment structures

- Alternate drilling techniques

- Improved container integrity sensors

- Substitutes for hazardous chemicals to implement waste mirimization

- Decontamination techniques that do not generate mixed wastes

- In excavation secondary wastes

- Equipment modifications for ease of decontamination

- Improved remote size reduction techniques

- In excavation cutting equipment

- Transportable size and volume reduction equipment. 
This page intentionally left blank. 


\section{C.1 - HANFORD ENVIRONMENTAL COMPLIANCE PROJECT}

Increased funding requirements for the Hanford Environmental Compliance Project have led to its redesignation as a major system acquisition in August 1990. This designation moves approval authority for key decisions, validations, and cost (greater than $\$ 50$ million) and schedule (greater than 6 month) changes from a program executive to the acquisition executive. As a major system acquisition, the DOE-HQ Energy Systems Acquisition Advisory Board must review and make recommendations for new projects to the acquisition executive.

Because the project is in mid-stream, Hanford Environmental Compliance Project management will propose that prior key decisions be 'grandfathered.' The project plan has been updated and will be sent to DOE-HQ for review in June.

The Hanford Environmental Compliance Project includes those capital improvements deemed necessary to support DOE's commitment to achieve compliance with applicable environmental requirements at the Hanford Site. In February 1987, DOE prepared a budget request to Congress to establish line item funding for the project. The line item targeted approximately $\$ 180$ million in capital funding in FY 1989 through FY 1995 for new facility construction and upgrades to existing facilities.

The Hanford Environmental Compliance Project will help ensure environmental compliance. It includes subprojects for liquid effluent treatment and disposal, groundwater monitoring, hazardous waste storage, analytical support upgrades, and environmental control upgrades of existing facilities. Its 1989 and 1990 subprojects were validated for funding appropriations of $\$ 12$ million and $\$ 27$ million, respectively. The FY 1991 and 1992 subprojects have also been validated and conceptual designs have been completed.

The total estimated cost for the Hanford Environmental Compliance Project is now defined at $\$ 224.3$ million. Subprojects included in the Hanford Environmental Compliance Project, estimated cost, schedule, and location are shown in Table $\mathrm{C}-1$. 
Table $\mathrm{C}-1$. Subprojects Included in Hanford Environmental Compliance Project.

\begin{tabular}{|c|c|c|c|c|c|}
\hline \multirow{2}{*}{$\begin{array}{l}\text { Project } \\
\text { number }\end{array}$} & \multirow{2}{*}{ Subproject } & \multirow{2}{*}{$\begin{array}{l}\text { Total } \\
\text { estimate to } \\
\text { complete } \\
(x \$ 1,000)\end{array}$} & \multicolumn{2}{|c|}{ Schedule } & \multirow{2}{*}{$\begin{array}{c}\text { Location } \\
\text { (areas/facilities) }\end{array}$} \\
\hline & & & start ${ }^{b}$ & End $^{c}$ & \\
\hline$H-017 H$ & $\begin{array}{l}\text { Groundwater Monitoring Well } \\
\text { System }\end{array}$ & $\$ 12,000$ & $01 / 89$ & $03 / 93$ & $\begin{array}{l}\text { Hanford Site (approxi- } \\
\text { mately } 165 \text { wells) }\end{array}$ \\
\hline$W-007 H$ & $\begin{array}{l}\text { B Plant Process Condensate } \\
\text { Treatment Facility }\end{array}$ & 14,700 & $01 / 89$ & $04 / 93$ & 200-East/B Plant \\
\hline$W-020 H$ & $\begin{array}{l}\text { Waste Management fagilities } \\
\text { Cathodic Protection }\end{array}$ & 7,100 & $01 / 89$ & $09 / 92$ & $\begin{array}{l}200 \text {-West, } 200 \text {-East/piping } \\
\text { and tanks associated with } \\
\text { various facilities }\end{array}$ \\
\hline$V-791 H$ & $\begin{array}{l}300 / 400 \text { Area Waste Water } \\
\text { Facility }\end{array}$ & 1,500 & $08 / 89$ & $10 / 90$ & 300,400 Areas \\
\hline$W-016 H$ & $\begin{array}{l}\text { Radioactive Mixed Waste Storage } \\
\text { Facility }\end{array}$ & 8,700 & $04 / 89$ & $09 / 93$ & 200-West \\
\hline B- $680 \mathrm{H}$ & $\begin{array}{l}\text { Plutonium Finishing Plant } \\
\text { Liquid Low-Level Waste System } \\
\text { Modification }\end{array}$ & 6,900 & $11 / 90$ & $09 / 93$ & $\begin{array}{l}200-\text { West/Plutonium } \\
\text { Finishing Plant }\end{array}$ \\
\hline $\mathrm{C}-031 \mathrm{H}$ & $\begin{array}{l}\text { Plutonium Finishing Plant } \\
\text { Liquig Effluent Treatment with } \\
\text { TRUEX }\end{array}$ & 17,400 & $07 / 91$ & $10 / 96$ & $\begin{array}{l}200 \text {-West/Plutonium } \\
\text { Finishing Plant }\end{array}$ \\
\hline $\mathrm{W}-\mathrm{O} 10 \mathrm{H}$ & $\begin{array}{l}\text { B Plant Environmental } \\
\text { Compl iance Upgrade }\end{array}$ & 3,500 & $01 / 90$ & $03 / 92$ & 200-East/B Plant \\
\hline $\mathrm{W}-019 \mathrm{H}$ & $\begin{array}{l}\text { Waste Sampling and } \\
\text { Characterization Facility }\end{array}$ & 16,600 & $01 / 90$ & $09 / 91$ & 200-West/Redox Facility \\
\hline$W-024 \mathrm{H}$ & $\begin{array}{l}\text { B Plant Radiological and } \\
\text { Contaiment Upgrades }\end{array}$ & 12,000 & $01 / 91$ & $03 / 95$ & 200-East/B Plart \\
\hline $\mathrm{H}-041 \mathrm{H}$ & $\begin{array}{l}\text { Environmental Hot Cell } \\
\text { Expansion }\end{array}$ & 13,800 & $01 / 91$ & $09 / 93$ & 200-West/Redox Facility \\
\hline $\mathrm{C}-018 \mathrm{H}$ & $\begin{array}{l}\text { 242-A Evaporator/PUREX Liquid } \\
\text { Effluent Treatment Facility }\end{array}$ & 52,600 & $01 / 91$ & $06 / 94$ & 200-East/PUREX \\
\hline$L-045 H$ & $\begin{array}{l}300 \text { Area Treated Effluent } \\
\text { Disposal Facility }\end{array}$ & 14,700 & $01 / 92$ & $12 / 94$ & $300 /$ To be determined \\
\hline $\mathrm{H}-049 \mathrm{H}$ & $\begin{array}{l}200 \text { Area Treated Effluent } \\
\text { Disposal Facility }\end{array}$ & 42,800 & $01 / 92$ & $06 / 95$ & $200 /$ To be determined \\
\hline
\end{tabular}

aDates subject to change depending on availability of funding.

Start definitive design.

dConstruction complete (not necessarily ready to proceed with operation).

dprogrammatic changes have placed these subprojects on hold. 


\section{C.2 - SOIL COLUMN DISCHARGE ALTERNATIVES}

Congress directed DOE to provide a document entitled Plan and Schedule to Discontinue Disposal of Contaminated Liquid Effluents Into the Soil Column at the Hanford Site.' This document presented an implementation $\mathrm{plan}$ for providing alternative effluent treatment and disposal of contaminated effluents being discharged to the soil column on the Hanford Site.

The original strategy for implementation of alternative treatment and disposal systems included the prioritization of effluent streams into two phases. The Phase I streams were considered of higher priority; alternative treatment and disposal systems for those streams would be implemented by 1995 within schedule and funding constraints. Those streams designated Phase II would be included in projects addressed after completion of the Phase I projects.

Based on consideration of the Clean Water Act, and the Washington Water Pollution Control Law, the best available technology economically achievable would be evaluated and applied to all discharges going to the soil column. The process of selecting and implementing alternative treatment and disposal technology would include preparation of required National Environmental Policy Act documentation.

Significant progress has been made toward the implementation of these actions since the original plan and schedule were issued. Several modifications also have been made to the implementation strategy. These changes resulted from altered facility missions, changing regulatory positions, and experience gained during implementation of the original plan and schedule. They were reflected in the Annual Status Report of the Plan and Schedule to Discontinue Disposal of Contaminated Liquids into the Soil Column at the Hanford Site. ${ }^{3}$

The Status Report also presented a review of the approach that established the Phase I and II priorities. In the revised priority list (Westinghouse Hanford Company, WHC-EP-0196-2), the following effluents were identified as Phase I streams:

- N Reactor effluent

- PUREX chemical sewer

${ }^{1}$ U.S. Department of Energy-Richland Operations Office, 1987, Plan and Schedule to Discontinue Disposal of Contaminated Liquid Effluents Into the Soil Column at the Hanford Site, DOE 065, Richland, Washington.

${ }^{2}$ Best available technology does not mean zero discharge or clean discharge.

${ }^{3}$ Westinghouse Hanford Company, 1989, Annual Status Report of the Plan and Schedule to Discontinue Disposal of Contaminated Liquids into the Soil Column at the Hanford Site, WHC-EP-0196.2, Richland, Washington. 
- PUREX process condensate

- PUREX ammonia scrubber condensate

- $\mathrm{UO}_{3}$ Plant process condensate

- $\mathrm{UO}_{3}$ Plant wastewater

- B Plant chemical sewer

- B Plant process condensate

- Plutonium Finishing Plant wastewater

- 222-S Laboratory wastewater

- 2101-M Laboratory wastewater

- T Plant wastewater

- 300 Area process wastewater

- PUREX steam condensate

- B Plant steam condensate

- S Plant wastewater

- 242-A Evaporator process condensate

- 2724-W laundry wastewater

- 163-N Demineralizer wastewater.

The following effluents were designated as Phase II streams:

- 242-S Evaporator steam condensate

- AY/AZ Tank Farm steam condensate

- 209-E Laboratory wastewater

- 183-D filter backflush wastewater

- PUREX cooling water

- B Plant cooling water

- 241-A Tank Farm cooling water

- 242-A Evaporator cooling water

- 242-A Evaporator steam condensate

- 244-AR Vault cooling water

- T Plant Laboratory wastewater

- 284-E Powerplant cooling water

- 284-W Powerplant cooling water

- 400 Area secondary cooling water.

The current strategy involves a number of projects to address the higher priority Phase I streams by June 1995, deferring the resolution of issues on the lower priority Phase II streams until sometime after that date but before December 1999. The best available technology treatment, either source controls, end-of-pipe treatment, or both, will be implemented for all streams.

"We discontinued this effluent because we no longer use the laboratory. 
Also, wherever needed, ccilection, retention, and additional treatment capabilities will be provided. The DOE will seek permits for the final disposal of these streams, whether to State-Approved Land Disposal Structures or to the Columbia River, according to the State of Washington regulations.

Please see Section A.13 for more information. 


\section{C.3 - HANFORD WASTE VITRIFICATION PLANT PROJECT}

Status

- Project validated FY 1987

- Plant preliminary design complete; detailed design initiated in January 1990

- Construction to start April 1992; complete 1998.

- Operations to start December 1999.

- Erchitect/engineer contractor is Fluor Daniel, Inc.

- General construction contractor is UE\&C-Catalytic Inc.

- Estimated cost is $\$ 1,060$ million (capital cost)

- FY 1991 budget is $\$ 60.0$ million

- TY 1992 budget is $\$ 119.0$ million.

- Estimated total project cost is $\$ 1.600$ million.

\section{Plant Design}

The vitrification process is based on technoiogy and engineering developed at PNL. The DOE has built a similar plant in Savannah River, South Carolina. The plant is being cold tested now. Hot startup is scheduled for 1992. Another plant is being built in West Valley, New York. In addition, France, Germany, Great Britain, and Japan have vitrification plants built or under construction. Hanford Site engineers interact extensively with engineers at these plants to exchange technical information and to learn from their successes and failures.

The Hanford Waste Vitrification Plant will be built near B Plant in the 200 East Area. The vitrified waste will be contained in steel canisters $3 \mathrm{~m}$ $(10 \mathrm{ft}$ ) tall by $60 \mathrm{~cm}(2 \mathrm{ft})$ diameter. Canisters will be produced and stored at the facility until a permanent repository is available. The storage area for the canisters is modular in design and can be expanded as necessary. The present design has storage capacity for 2,000 canisters.

\section{Operations}

When operating, the Hanford Waste Vitrification Plant will have a staff of approximately 300 people. It will operate 24 hours a day. The glass production rate is $100 \mathrm{~kg}(220 \mathrm{lb}) /$ hour with more than 300 canisters produced per year. The melter operates at $1,149^{\circ} \mathrm{C}\left(2,100^{\circ} \mathrm{F}\right)$ with a predicted service 1 ife of 3 to 5 years. 


\section{4 - CENTRAL WASTE COMPLEX}

Status

- Hanford Central Waste Complex site evaluation report released in 1988

- Storage of low flashpoint mixed waste begun in 1988

- Eight low flashpoint storage modules operating by FY 1990

- Thirteen $372 \mathrm{~m}^{2}\left(4,000 \mathrm{ft}^{2}\right)$ mixed waste storage buildings operating by FY 1990

- Construction begun on Phase I of Large Mixed Waste Storage Facility

- Design completed on Phases II through IV of large mixed waste storage facility

- Engineering study completed on office support complex

- Engineering study under way on Enhanced Radioactive and Mixed Waste Storage Phase V.

\section{Description}

The Hanford Central Waste Complex provides storage and treatment of solid waste at the Hanford Site. The complex will perform waste receipt, storage, repackaging, volume reduction, certification, treatment, and offsite shipment for a high percentage of solid TRU mixed wastes generated, stored, and received at the Hanford Site. Some newly generated low-level waste also will be processed in the WRAP Facility.

The following facilities exist or will be included in the Hanford Central Waste Complex:

- Low Flashpoint Storage Modules. Eight are operational. The modules are small pre-engineered buildings with $176 \mathrm{ft}^{2}$ of floor space each. They are used to store flammable and low-level mixed waste with flashpoints below $38^{\circ} \mathrm{C}\left(100^{\circ} \mathrm{F}\right)$. A study is under way to modify two of the modules to store low flashpoint TRU waste. The cost per module is $\$ 50,000$.

- Mixed Waste Storage Buildings. Thirteen are operational. The 2401-W, 2402-W, and 2402-WB through 2402-WL buildings are all operational. They are being used to store most categories of mixed waste, including TRU. The floor space of each building is $372 \mathrm{~m}^{2}$ $\left(4,000 \mathrm{ft}^{2}\right)$, with a capacity of 1,000 drums. The cost per building is $\$ 300,000$. 
- Large Mixed Waste Storage Facility. The large mixed waste storage facility will consist of four separate buildings (Phases I through IV). They will be used to store specific categories of lowlevel mixed waste. The first three buildings each will have a 11,000 55-gallon drum-equivalent capacity and the fourth will have a 18,000-drum-equivalent storage capacity. The total estimated cost for the first phase is $\$ 2.2$ million.

- Enhanced Radioactive and Mixed Waste Storage Phase V. This facility will consist of three storage buildings, plus support buildings primarily for storage of retrieved Hanford Site wastes. It will have space for about 27,000 drum equivalents of radioactive and mixed waste, low-level waste, and TRU waste awaiting treatment or disposal. Total estimated cost is $\$ 8.4$ million.

- Waste Receiving and Processing Facility. The WRAP will perform waste receipt, repackaging, certification, treatment, and volume reduction for low-level waste, TRU, low-level mixed waste, and TRU mixed waste. Not all functions will be required for each waste type. An adjoining storage facility will be necessary for storage of waste waiting for WRAP processing. Retrieval facilities will be required to exhume the stored TRU wastes, which will be a significant portion of WRAP throughput. (WRAP and these related facilities are discussed in detail in Section C.5)

- Hanford Central Waste Support Complex. Activities in the Hanford Central Waste Complex require additional change room and office building space. This will be provided in two buildings or phases plus temporary buildings. 


\section{C.5 - WASTE RECEIVING AND PROCESSING FACILITY}

Status

- Module I validated in FY 1989

- Conceptual design completed for Module I in FY 1989

- Advanced conceptual design for Module I started in FY 1990, but was terminated because of funding constraints. The advanced conceptual design will be done at the same time as the definitive design, which began in January 1991

- Conceptual design started for Modulc II in FY 1990

- Module II validation expected in FY 1991

- Engineering study for TRU retrieval for WRAP processing started in FY 1990

- Engineering study for Enhanced Radioactive and Mixed Waste Storage Phase V started in FY 1990

\section{Description}

The WRAP Facility will provide the solid waste treatment required for radioactive and mixed solid wastes at the Hanford Site. In urder to accelerate the project, it was divided into two phases. The initial phase uses established technology, which allows more time to better define the remaining functions to be included in the second phase.

The first phase is called WRAP Module I. Module I will receive contacthandled TRU, mixed TRU, low-level, and mixed low-level solid wastes. These wastes are to be received from storage or are newly generated. Newly generated wastes originate either on site or off site, and will have been certified by the generator in accordance with the Hanford Site Waste Radioactive Solid Waste Acceptance Criteria. The facility will provide for examination, certification, and shipping (for both modules) of boxes and drums of contact-handled TRU wastes for disposal in accordance with the TRUPACT-II (transuranic packaging transporter) criteria and Waste Isolation Pilot Plant waste acceptance criteria. Other waste types will be examined, packaged, and certified to the appropriate criteria and shipped for disposal. The facility will do limited treatment of hazardous wastes and decontaminate small process support items. Definitive design will begin in FY 1991, and operation will begin in FY 1996. The total estimated cost for Module I is \$54 million.

The second phase is called WRAP Module II. This phase will receive remote-handled TRU wastes, low-level mixed wastes, newly generated contaminated retrieval equipment up to $(60 \mathrm{ft})$ long, and wastes in contairiers larger than can be handled in Module I. The facility will provide for 
permanent disposal of wastes in the Waste Isolation Pilot Plant or the permanent disposal site at Hanford, as appropriate for the waste type. The total estimated cost for Module II is $\$ 300 \mathrm{million}$.

An engineering study for a retrieval facility to provide the necessary equipment, weather, and contamination protection to retrieve TRU waste stored underground for WRAP processing and shipment to Waste Isolation Pilot Plant began in FY 1990. It is now planned to validate this project in FY 1994.

An engineering study for an enhanced radioactive and mixed waste storage facility for newly generated and stored waste awaiting WRAP processing began in FY 1990.

\section{Operations}

Module I is scheduled to be operational in FY 1996 and Module II ir. FY 1999. The schedule for WRAP is based on projected funding needs being provided. Module I operation is Milestone M-18-00 and Module II operation is Milestone M-19-00 in the Action Plan of the Tri-Party Agreement.

The WRAP facility must be able to process all stored and newly generated TRU waste by 2013 , the date of the last shipment of Hanford TRU waste to Waste Isolation Pilot Plant before that facility closes. Low-leve? waste and mixed waste will also be processed in WRAP to meet regulatory requirements for treatment and disposal. 


\section{C.6 - GROUT DISPOSAL PROGRAM}

The Grout Treatment Facility will remove stored liquid tank wastes and convert them into a solid for environmentally safe disposal. About 164 milition liters ( 43 million gallons) of mixed waste will be processed for disposa? between 1992 and 2014. The mixed waste will be disposed of in accordance with a permit issued by Ecology and DOE orders for disposal of lowlevel waste.

The Grout Treatment Facility consists of the Dry Materials Facility, a grout mixing and pumping facility called the Grout Processing Facility, and the below-grade disposal vaults. The Grout Processing Facility combines the liquid waste with dry materials, such as cement, flyash, and blast furnace slag. This produces a grout slurry that is pumped into large underground disposal vaults where the slurry solidifies.

The disposal vault is approximately $15 \mathrm{~m}(50 \mathrm{ft})$ wide, $38 \mathrm{~m}(125 \mathrm{ft})$ long, and $10 \mathrm{~m}(34 \mathrm{ft})$ deep. The overall design of the disposal system also includes several engineered barriers. The reinforced concrete vault is surrounded by a l-m-thick asphalt pavement barrier to inhibit the release of contaminants to the environment. The vault and barrier is covered with a RCRA compliant soil/clay textured closure cover, which is installed over the vaults after grout filling and solidification. The vault design also includes provisions for installation of a natural protective barrier early in the next century.

The design of the mixed waste disposal system was modified to include lessons learned during construction and operation of the first grout vault. In July 1989, 3.8 million liters (1 million gallons) of low-level waste was processed and disposed of. The design now includes additional barriers found to be required by computer modeling of the system's performance over 10,000 years.

In addition to vault construction, significant activities for the grout program include completion of the Final Safety Analysis Report, completion of the Part $B$ permit application, final review and approval of the Performance Assessment and additional formulation development to resolve high grout temperatures and meet more stringent criteria. The draft Final Safety Analysis Report is in the early stages of review by DOE.

Considerable work has taken place to evaluate the grout facilities for compliance with DOE orders and regulations. The Part $B$ permit application is nearing completion after several rounds of comments (Notice of Deficiencies) have been resolved with Ecology. The Part B permit application will be submitted to Ecology and EPA during the fourth quarter FY 1991 and a permit is expected during the second quarter of FY 1992.

The Performance Assessment, which evaluates the long-term impact of the grout disposal action, has been prepared and submitted to the DOE-HQ peer review panel for final review and approval. This is the first final Performance Assessment to be reviewed by the peer review panel. 
The grout formulation development efforts were significantly redirected in February 1991, to evaluate and develop alternate formulations to resolve difficulties with excessive grout temperature rise caused by heat of hydration, low leach resistance, low compressive strength, and excess liquid remaining after grout curing. This work involves the resources of Westinghouse Hanford, PNL, and Oak Ridge National Laboratory.

A significant activity $\mathrm{planned}$ for $F Y 1992$ is to conduct the Operational Readiness Review which will precede the facility start-up for grouting doubleshell tank wastes.

The DOE has invested approximately $\$ 98$ million in the program through the end of FY 1990. Current estimates for grout production costs are approximately $\$ 15$ per gallon of tank waste. The total lifetime cost of the program to dispose of all low-level double-shell tank waste is approximately $\$ 700$ million.

Much of the program's budget of $\$ 28$ million ir iy 1991 and increasing budgets in the out years will pay for construction of mixed-waste disposal vaults. The first of these vaults is scheduled to be completed early in 1992 . Processing 3.8 million liters ( 1 million gallons) of waste feed to fill this vault is scheduled to begin in the fall of 1992. The Grout Treatment Facility will reach peak production rates in FY 1994 and be capable of processing 15 million liters (4 million gallons) of waste annually. The grout program directly and indirectly employs about 250 people. 


\section{C.7 - 242-A EVAPORATOR}

The 242-A Evaporator concentrates dilute double-shell tanks wastes to reduce the volume of waste in the tanks. Previously, we treated the water removed from the waste by evaporation (condensate) by filtration and ion exchange before discharging it to retention basins. After sampling and confirming its acceptability for discharge, we discharged the condensate from the basins to the 216-A-37 Crib.

We can no longer discharge the condensate to the crib. This is because products of processing potential 1 isted dangerous waste are now al so considered a listed dangerous waste. This concern arose in April 1989. As a precautionary measure, the 242-A Evaporator was placed in temporary layup while awaiting resolution of the 1 isted waste issue. This required us to develop alternatives for disposing of the condensate.

Operation of the 242-A Evaporator is vital to supporting Tri-Party Agreement milestones to stabilize single-shell tank waste and pretreat and dispose of double-shell tank waste. Double-shell tank space to support tank stabilization is insufficient unless the 242-A Evaporator can reduce stored waste volumes.

Westinghouse Hanford is pursuing installation of a Liquid Effluent Retention Facility to store the evaporator condensate. It will be stored in these basins until compliant treatment and disposal systems are put in place. At the same time, we are upgrading the evaporator to extend its operational 1 ife beyond the year 2000. The current schedule shows evaporator restart and operation of the storage units at the end of December 1991. Treatment and disposal systems are targeted to be operational by late calendar year 1994 .

\section{C.7.1 LIQUID EFFLUENT RETENTION FACILITY}

The Liquid Effluent Retention Facility is being constructed to provide interim storage of 242-A Evaporator process condensate suspected of containing listed waste. We can no longer discharge this effluent to the ground ( $v$ ia the 216-A-37 Crib) because of this potential. Discharge of this effluent cannot resume until a suitable disposal alternative is in place.

The strategy developed is as follows. We will build a treatment facility to remove constituents of concern. This will allow effluent disposal to comply with the regulations. Then we will discharge treated effluent to an approved disposal site. The Liquid Effluent Retention Facility will provide interim retention capacity until the treatment facility is available.

The Liquid Effluent Retention Facility will consist of a retention basin system composed of three separate cells. Each cell will have a design capacity of 24.6 million liters $(6.5$ million gallons) (73.8 million liters [19.5 million gallons] total capacity). Forty-nine million liters (13 million 
gallons) of volume will be dedicated to the evaporator process condensate, and 24.6 million liters ( 6.5 million gallons) will be reserved for contingency capacity.

As a result of Secretary Watkins' October announcement to place the PUREX Plant on standby, PUREX effluents have been phased out of this facility's design.

Each basin cell will have a floating cover and a primary and secondary composite liner. These composite liners will consist of high-density polyethylene membranes and clay mixtures. A leachate collection system will be installed between the two liners. The system will be consistent with RCRA requirements. Each cell will be approximately $82 \mathrm{~m}(270 \mathrm{ft})$ wide by $100 \mathrm{~m}$ $(330 \mathrm{ft})$ long with an operating storage depth of $6.4 \mathrm{~m}(21 \mathrm{ft})$. The design life of the basin and associated piping is 30 years.

After we have developed and implemented treatment methods, we will stop using the Liquid Effluent Retention Facility for these effluents. Then we will consider the facility basins for alternate uses or decommissioning. We are considering the alternatives of using the facility to hold other effluent streams while we determine whether it is necessary to treat them.

\section{C.7.2 242-A EVAPORATOR/PUREX PROCESS CONDENSATE TREATMENT FACILITY}

This project is number $\mathrm{C}-\mathrm{O} 18 \mathrm{H}$ in the Hanford Environmental Compliance Project (see Table $(-1$ ).

The 242-A Evaporator/PUREX Plant Condensate Treatment Facility will treat effluent from the 242-A Evaporator and effluent stored in the Liquid Effluent Retention Facility. The facility is also being to treat two PUREX Plant process condensate streams. The PUREX Plant is not operating. Plant restart depends on the outcome of an EIS (see Section B.12.1). The treatment facility will permit disposal of the effluents in compliance with applicable regulations.

The tratment facility's conceptual development phase is complete. A request for proposals for design and construction of the treatment facility was issued May 3, 1991. A contract will be placed and a notice to proceed issued to the offsite design/construct contractor by December 6,1991 . The facility's hot startup date is currently targeted for June 3, 1994. Facility permitting and treated effluent delisting activities are in progress.

Two alternatives will be pursued for disposal of the treated effluent: soil column disposal and discharge to the Columbia River. The river discharge alternative, if chosen, will require a National Pollution Discharge

I Elimination System permit. At present, soil column discharge is the baseline a)ternative.

The facility's initial operations will emphasize treatment of evaporator effluent stored in the Liquid Effluent Retention Facility. When the Liquid 
Effluent Retention Facility basins are emptied, 242-A Evaporator process condensate will be routed directly to the treatment facility.

The treatment facility will be designed so as not to preclude the future treatment of other 200 Area effluent streams. The facility is planned to provide standby effluent treatment capability for the 200 Area Treated Effluent Disposal Facility (project number $\mathrm{W}-\mathrm{O} 49 \mathrm{H}$ in the Hanford Environmental Compliance project) beginning June 30, 1995. 


\section{C.8 - SUBMARINE REACTOR COMPARTMENTS}

The Department of the Navy continues to ship defueled submarine reactor compartments to Hanford. The compartments are from nuclear submarines the Navy has decommissioned. As of June 1, 1991, Hanford has received 16 compartments in the $218-E-12 B$ burial ground. Four more are expected in 1991.

The first reactor compartment arrived in April 1986, and was classified as low-level waste. Thr: subsequent discovery of PCBs in the compartments and changing regulations with respect to the waste classification of lead, have combined to change the waste classification to mixed waste. The Navy has agreed with Ecology to regulate the compartments as both a Toxic Substances Control Act waste and a RCRA waste. The Toxic Substances Control Actregulated PCBs are fixed in place as an integral part of the electrical wiring insulation, and represent only $0.000000025 \%$ by weight of the waste. The RCRA (state only)- regulated lead is used as radiological shielding. Based upon agreement from the State of Washington and EPA Region 10, reactor compartment shipments are allowed to continue.

Regulations require that RCRA and Toxic Substances Control Act waste burial trenches have a liner and a leachate collection/removal system. DOE$\mathrm{RL}$, with Puget Sound Naval Shipyard support, maintains that the submarine reactor compartment packages meet or exceed the minimum technological requirements for a liner and leachate collection/removal system. In July 1990 , the DOE-RL requested from Ecology an exemption to the liner and leachate collection/removal system requirement. This issue must be resolved before the compartments can be buried. The EPA has indicated that if the state grants the exemption with respect to the state-only regulated lead, the EPA will grant an exemption to the Toxic Substances Control Act regulation for the PCBs.

Each compartment is cylindrical in shape and weighs approximately 1,000 tons. Each measures about 32 feet in diameter and 38 feet in length. A transport contractor, under contract to the Puget Sound Naval Shipyard, transports the compartments about 26 miles, from the Port of Benton to Trench 94 in the 200 East Area burial ground. The Westinghouse Hanford Submarine Reactor Disposal Program coordinates and directs the Hanford Site support of the move. Support includes scheduling of security, safety, radiological protection, etc., preparation of required permits and documentation, (welding and cutting, wide load, radioactive shipment record, etc.), and the release of any information about the submarine reactor compartments.

The Navy officially transfers each compartment to Westinghouse Hanford, representing the DOE-RL. This occurs when the compartment has been welded to its support columns, the transport contractor has cumpleted his contractual obligations, and has vacated the burial trench. 


\section{C.9 - STATE CONCERN THAT WASTE TO BE GROUTED IS HIGH-LEVEL WASTE}

In 1988, the NRC raised the concern, based on the HDW-EIS, that some double-shell tank waste to be grouted might be HLW and under its licensing jurisdiction. Its concern centered on the HLW definition in 10 CFR Part 50, Appendix $F$, which is source based rather than concentration or risk based.

Hanford Site personnel met with the NRC in 1988 and 1989 to describe the waste to be grouted and explain why it was low-level waste. The NRC decided it would not be HLW if it qualified as "incidental waste;" that is, while some of the waste may have originated as an HLW source, it had been treated so that now it was primarily chemicals used in the process and contaminated with only small residual amounts of radionuclides. In March 1989, DOE-RL formally requested NRC's concurrence that the waste to be grouted was not HLW and therefore not under its jurisdiction. The bases for this determination included a commitment to further treat one category of waste to further reduce the radionuclide content.

During the summer of 1989, Washington State became concerned that NRC would reach a decision without a public hearing process. The NRC and Hanford Site personnel met with the State and involved Indian nations in August, and in September 1989, the NRC formally concurred with DOE-RL's request that the waste be determined not to be HLW.

The State is still concerned that this determination did not go through a public process. Environmental groups are also protesting. The Hanford Site position is that grouting these wastes was described in the HDW-EIS, which went through an extensive public process.

On January 2, 1990, the States of Washington and Oregon and the Yakima Indian Nation petitioned NRC "to exercise its rule making authority, offer adequate opportunity for public comment, and adopt a regulation concerning classification of Hanford HLW currently stored in retrievable, surface, storage facilities." The State met with NRC in February 1990 and agreed to revise its petition, which was submitted on July 27,1990 . The petitioners are asking the NRC to amend 10 CFR Part 60.2 to clarify the definition of defense HLW and the definition of a HLW facility in a formal rulemaking process in which the public can participate. They want each tank of waste to have the largest technically achievable amount of radioactivity removed prior to disposal and require that the heat produced by the radioactivity and the heat of reaction during grouting will be within temperature limits to ensure the grout will have long-term waste stability.

The NRC issued the petition in the Federal Register for comment in December 1990. The comment period closed on March 18, 1991. The NRC will review comments and decide whether to accept the petition and proceed with rulemaking or to reject the petition. 


\section{C.10 - ENVIRONMENTAL AND MOLECULAR SCIENCES LABORATORY}

The Environmental and Molecular Sciences Laboratory is a major new research facility to be constructed at the PNL. As a designated DOE national scientific collaborative facility, the Environmental and Molecular Sciences Laboratory will provide a focal point for molecular-level research in the United States.

The new laboratory will bring together permanent staff and visiting researchers from universities, industry, and national laboratories in a dynamic research environment where they can develop new knowledge, understanding, and technology. Molecular-level research programs to be conducted in the Environmental and Molecular Sciences Laboratory will explore:

- Basic chemical processes that control contaminant transport and transformation

- Material issues that affect waste management and environmental restoration

- Biosystems that might be used for remediation

- Health effects caused by exposure to toxic substances.

The PNL has recruited associate directors and senior staff, and research programs are under way in interim facilities.

The Environmental and Molecular Sciences Laboratory is a joint project of DOE's Offices of Energy Research and Environmental Restoration and Waste Management. The DOE FY 1991 budget included funding for the definitive design. On February 15, 1991, representatives from DOE-RL and the Zimmer, Gunsul, Frasca Partnership of Portland, Oregon, met at PNL to sign the architect/ engineering contract. This kick-off meeting marked the beginning for construction of the Environmental and Molecular Science Laboratory, which is scheduled for completion by 1995 .

The FY 1992 Federal budget proposed by the President includes $\$ 17.1$ million to begin construction of the laboratory as well as the necessary commitment of all the funds for the ful1, 5-year \$217.8-million construction project. The new laboratory will be built south of the 300 Area. 


\section{C.11 - IRRADIATED FUEL STORAGE AND PROCESSING}

The DOE does not designate irradiated fuel to be a waste and it is not included in the waste inventory.

\section{C.11.1 IRRADIATED FUEL INVENTORY, STORAGE MODES, AND INTERIM ACTIONS}

Approximately 2,100 metric tons uranium of $N$ Reactor fuel will remain stored in KE and KW Basins. We plan to encapsulate the fuel now stored in open-topped canisters in KE and possibly consolidate the $\mathrm{N}$ Reactor fuel into one basin.

About 10 metric tons heavy metal of fuel from the Fast Flux Test Facility continue to be stored at the 400 Area. A program is under way to move some of the fuel to cask storage to support extended operations.

About 16 metric tons uranium of Pressurized Water Reactor Core II fuel from the Shippingport reactor is stored at $T$ Plant and will remain there. A small amount of aluminum clad, single-pass reactor fuel is in PUREX and $K$ Basin storage pools (about 2.8 metric tons uranium at PUREX and 0.5 metric tons uranium in $\mathrm{K}$ Basins) and will remain there for now.

In addition, about $350 \mathrm{~kg}$ of other spent fuel is retrievably stored in shielded containers in the 200 West Area waste burial grounds and at the 324 Hot Cell Facility in the 300 Area. This fuel is primarily Fast Flux Test Facility and EBR-II fuel pin pieces from the post-irradiation examination programs.

An environmental assessment has been issued for the $N$ Reactor fuel encapsulation. A Finding of No Significant Impact has been-drafted and is being reviewed.

\section{C.11.2 IRRADIATED FUEL DISPOSITION}

In the past, irradiated fuels from Hanford reactors were processed through large chemical processing plants, like the PUREX Plant, to recover plutonium for defense and research purposes. This program changed in October 1990 when Secretary Watkins announced that plutonium from Hanford was no longer needed. He announced that DOE would prepare an EIS to determine the appropriate method for disposition of the inventory of irradiated fuel at Hanford.

The EIS will address disposition of all the fuels listed above. Once an EIS decision is made, we will implement the chosen alternative. The public 
scoping process will formally determine the study's scope. Potential options currently under consideration include:

- No action

- Processing at PUREX

- Storing in a new onsite facility

- Shipping the fuel to Savannah River Site for processing

- Converting the fuel to a form suitable for emplacement in a geologic repository.

Also at the Hanford Site are 129.7 metric tons uranium of spent nuclear fuel from the Washington Public Power Supply System Plant 2. Though located on the Hanford Site, the reactor is managed by the Supply System, not DOE. That fuel is stored in water basins at the reactor.

\section{C.11.3 PUREX STATUS AND PLANS}

After the end of the stabilization run in Harch 1990, PUREX began a planned maintenance outage to make a number of plant upgrades. In parallel with the maintenance activities, we planned to complete substantial upgrades to the facility's Final Safety Analysis Report and Operating Safety Requirements. These activities were to be followed by an operating campaign to process the remaining weapons grade $\mathrm{N}$ Reactor fuel.

Once the Secretary announced that the Hanford plutonium was no longer needed, the PUREX staff was directed to place the plant ir a standdown condition. A management plan was issued and is being implemented at this time. The transition to standdown should be completed early this fall. This plan will reduce activities in the plant to minimum surveillance, maintenance of essential equipment (primarily ventilation systems) and engineering support of longer range planning and documentation upgrades.

It is anticipated that the standdown could last as long as 3 years (until an EIS is complete). This would be followed by a 2 - to 3-year ramp-up period if PUREX is chosen as the fuel's disposition option.

A Westinghouse Hanford task team is studying alternate uses for the PUREX Plant. If PUREX is not chosen for disposition of the fuel (or after that mission ends), we would pursue one of iho fn? ?uwing options:

- Alternate use of the facility. Specifics are not yet available

- No action

- Terminal cleanup. This would involve extensive flushing to remove radionuclides. 
Proposed DOE regulations require an EIS for decommissioning facilities like PUREX. The public will be involved in decisions about PUREX's final disposition. 


\section{C.12 - DOSE AND HEALTH STUDIES}

\section{C.12.1 HANFORD ENVIRONMENTAL DOSE RECONSTRUCTION PROJECT}

The data and models used in Phase I are now being evaluated to identify opportunities to reduce uncertainty and improve dose estimates. Researchers will identify and evaluate all pertinent data and examine and partially validate the models. They will calculate doses for Native American tribes in the region and selected persons included in the Hanford Thyroid Disease Study (see Section C.12.2) Researchers also will study groundwater contamination to the river and doses from releases to the river from 1944 to 1990.

The study was designed only to estimate past doses and does not attempt to link specific health effects to dose levels. A separate, Congressionally funded epidemiology study by the Centers for Disease Control is under way to determine whether a link exists between airborne iodine-131 from the Hanford Site and the incidence of thyroid disease in local populations.

Researchers are reconstructing several types of historical information to estimate doses: amounts and types of radionuclides emitted from Hanford Site facilities; transport patterns and amounts of radionuclides that travelled through the environment in air and water and concentrated in vegetation and foods and demographic, agricultural, and food consumption patterns that affected peoples' exposures to radionuclides.

The project, established in FY 1988, is managed by PNL under the direction of an independent Technical Steering Panel of national experis and representatives from Oregon, Washington, Indian tribes, and the public. The DOE has recently transferred management of the study to the Centers for Disease Control. The Technical Steering Panel hosts periodic public meetings to conduct business, review PNL work, and respond to public comments on the study.

Please see Section B.8 for environmental monitoring information.

\section{C.12.2 HANFORD THYROID DISEASE STUDY}

The Hanford Thyroid Disease Study is funded by the Centers for Disease Control in Atlanta, as directed by Congress. The primary purpose of this epidemiologic study is to determine whether thyroid disease is increased among persons exposed to the releases of radioactive materials (primarily iodine-131) from the Hanford Site. The diseases of greatest interest are hypothyroidism (underactive thyroid), benign thyroid nodules (1 umps), and thyroid cancer. The Fred Hutchinson Cancer Research Center in Seattle will conduct the study in collaboration with scientists at the Centers for Disease Control. 
The study will be conducted as a follow-up or cohort study. A sample of persons most 1 ikely to have been exposed to atmospheric releases of radioactive iodine from the Hanford Site will be identified from Washington State birth records, based on place and year of birth. A sample of comparable persons unlikely to have been exposed to the same releases will be identified in an identical manner.

Researchers will conduct personal interviews with each study subject (or next-of-kin if deceased) regarding details of their residential, medical, and personal habits histories. Researchers also will interview each subject's mother or close relative about aspects of the subject's childhood that are specific to the possibility of radioactive iodine exposure. A radiation dose to the thyroid will be estimated for each individual based on data collected by interview, using methods PNL developed as part of the Hanford Environmental Dose Reconstruction Project.

To verify reports of past thyroid diseases, medical records and pathology specimens will be sought and reviewed by medical experts. To identify thyroid disease, each study subject will be asked to undergo a clinical examination of the thyroid and to provide a small sample of blood. For those found to have a thyroid nodule, permission will be sought to obtain a sample of cells from the nodule for more complete diagnostic information.

\section{Schedule for the Study}

The initial phase of the study, which began in September 1989, is to develop a detailed study plan, or protocol. This protocol has been evaluated by scientists on the dose reconstruction Technical Steering Panel, collaborating scientists at the Centers for Disease Control, members of a Federal advisory committee appointed for this study, and members of the public. A final protocol has been submitted for approval by the Human Subjects Review Committee of the Fred Hutchinson Cancer Research Center and the Federal Office of Management and Budget.

Once approved, the study will be conducted in two stages. First, a pilot study will be undertaken to test the feasibility of the approach. About 560 people will be identified from persons born in Benton, Franklin, and Walla Walla counties between 1942 and 1946. About 100 people born in Stevens, Ferry, and Okanogan counties will be identified in the same manner. Using place of birth will assure adequate numbers of subjects with thyroid doses at the highest and lowest extremes of the dose distribution. Actual doses will, of course, be based on the data obtained in the dosimetry interview for each subject. Information obtained from the medical examinations and interviews will be used to revise the study protocol and to more accurately determine the number of people needed to conduct a full study. It is expected that the pilot study will be completed 12 months after Office of Management and Budget approva1.

The second stage of the project will expand the pilot study into a full epidemiologic study. Based on experience gained in the pilot study, it may be necessary to revise the criteria for selecting study subjects and/or to alter 
the ways in which information is collected from study participants. The full study is scheduled for completion by the end of 1994. At that time, findings will be made available to indicate whether there is evidence that thyroid disease is increased among persons exposed to the Hanford Site radiation releases.

\section{C.12.3 HANFORD WORKER MORTALITY STUDIES}

The Hanford Mortality Study is one of the most comprehensive efforts ever conducted to determine the health effects of exposures to low-level radiation on nuclear workers. Using mortality data from the $1940^{\prime} \mathrm{s}$, researchers examine the death rates among 44,000 Hanford employees. Epidemiologists from the Hanford Environmental Health Foundation collect occupational mortality data, which PNL statistician Ethel Gilbert analyzes. The study tracks workers throughout their careers at the Hanford Site as well as after they leave the site.

Gilbert has used two approaches to analyze the data. The first compares death rates of the Hanford Site workers with national death rates, accounting for such factors as age, sex, and the number of years employed. The Hanford Site death rates from nearly every disease, including most cancers, were substantially lower than the national average. This finding is typical of workers employed in industries free from serious hazards and reflects the "healthy worker effect," which results in part from the requirement of good health to be eligible for employment.

The second approach compared death rates by level of occupational radiation exposure. This approach is more informative for examining the specific effects of radiation exposure. Hanford Site researchers found no evidence of a positive correlation of mortality from all cancers combined or from causes other than cancer. Cancer death rates were essentially the same among workers who had received higher levels of radiation exposure and those who received little or no exposure.

The Hanford Site worker death rates from leukemia also showed no evidence of a correlation with radiation exposure. Leukemia has been shown to be strongly linked to high levels of radiation exposure at high doses and has a shorter latent period than most other cancers. Thus, if there were a radiation-related health problem at the Hanford Site, it would likely show up first as leukemia.

Gilbert emphasizes, however, that these results should not be interpreted as indicating that exposure to radiation at low doses is harmless. Even though no evidence of a correlation between radiation and all cancer or leukemia was found, the risk may simply have been too small to be detected. The findings are consistent with predictions based on currently accepted estimates of radiation risks.

Gilbert has analyzed numerous causes of death, including 17 categories of cancer. Of those, multiple myeloma, a rare bone marrow cancer, is the only disease to show a meaningful statistical association with radiation exposure. 
This correlation, based on deaths through 1981, resulted from three deaths of workers with multiple myeloma who had accumulated at least 5 rem of exposure.

Three additional deaths of persons with multiple myeloma who had received this level of exposure were identified after further analys is of recent data, including information on diseases that were not the cause of death. "We don't understand why there's a correlation for multiple myeloma but not for other diseases, such as leukemia," Gilbert said. "The recent data, however, lend credibility to the correlation. We're following this disease closely."

The DOE and its predecessor agencies began studying mortality of DOE site workers in 1965. The PNL and the Hanford Environmental Health Foundation assumed responsibility for the Hanford Mortality Study in 1977. The Hanford study is reviewed periodically by an advisory committee of eminent scientists from universities and non-DOE government agencies.

In 1977, the study's previous manager, Dr. Thomas Mancuso of the University of Pittsburgh, and his associates, Alice Stewart and George Kneale, published results of their analysis of the Hanford Site mortality data. Their analys is concluded radiation exposure below present government standards resulted in increased cancer deaths. This conclusion opposes the Hanford research team in the debate about the role of low-level radiation in causing cancer. In the summer of 1990, Hanford worker mortality data were provided to Dr. Alice Stewart for her reanalysis. She is not expected to complete her work until the summer of 1991 at the earliest.

According to Gilbert, the Mancuso/Stewart/Kneale analyses have serious flaws. Their findings have been criticized in print by many scientists, in a report by the General Accounting Office, and by a major committee of the National Academy of Sciences (BEIR III) that was concerned with risk estimates related to low-level radiation.

The Hanford mortality data have also been analyzed by scientists at the National Radiological Protection Board in Great Britain, and by scientists from the National Cancer Institute, the National Research Council, and Harvard University. Findings of these investigators agree with the conclusions of the Hanford research team.

Analyses of combined data (conducted by Gilbert) on workers at the Hanford Site, Oak Ridge National Laboratory, and Rocky Flats Weapons Plant have also been published. Data from all three studies will be a part of international combined analyses being coordinated by the International Agency for Research on Cancer and will include data from nuclear workers in the United States, United Kingdom, and Canada. Gilbert serves as the U.S. representative on the subcommittee responsible for planning these analyses.

Researchers from PNL and the Hanford Environmental Health Facility are also participating in DOE's Comprehensive Epidemiologic Data Resource Program. This program was established to develop a public use data set containing 
worker demographics, work histories, radiation and chemical exposures, medical information, vital statistics, and other health-related data on workers at DOE facilities. 


\section{C.13 - WASTE TANK SAFETY BACKGROUND}

This section examines safety issues related to the Hanford Site's singleand double-shell underground nuclear waste storage tanks. It also evaluates the chemical stability of the radioactive wastes in those tanks. More information about recent tank safety developments is in Section A.3.

\section{Background}

Between 1943 and 1964, 149 single-shell tanks were built to store liquid radioactive wastes. Today, they hold about 140 million liters $(37 \mathrm{million}$ gallons) of waste. The waste is in a variety of types: low-level, highlevel, hazardous, or plutonium-contaminated salt cake and sludge. Most of it is now solid.

The single-shell tanks are located on a plateau near the center of the Hanford Site. No wastes have been added to them since November 1980. Sixtysix of the 149 tanks are classified as "suspected leakers." An exact count isn't easy, because leaks from single-shell tanks are hard to detect, especially as the waste is mostly solid now. They may have leaked up to 2.8 million liters $(750,000$ gallons) of contaminated 1 iquid into the surrounding soil. Additional leak volume caused by adding cooling water to Tank A-105 is not in this estimate. It is likely this estimate will be upwardly revised if cooling water is added to the total leak and volume. In addition, about 450 million liters ( 120 million gallons) were directly discharged to cribs and trenches from single-shell tanks between 1946 to 1966.

In 1979, to halt or reduce effects of future leaks, removal of pumpable liquids from the single-shell tanks began. A total of 13 million liters ( 3.5 million gallons) of liquid waste was removed between 1979 and 1989. Forty-four tanks are left to be drained by September 1996. The liquid that can be pumped from within and from the surface of the waste is transferred to double-shell tanks.

Of the 149 single-shell tanks, 133 are $22.8 \mathrm{~m}(75 \mathrm{ft})$ in diameter and a maximum of 9 to $16 \mathrm{~m}(29.75$ to $54 \mathrm{ft})$ high. Their capacities range from 1.9 million to 3.8 million liters $(500,000$ to 1 million gallons). The remaining single-shell tanks have a similar design but are smaller: $6 \mathrm{~m}$ $(20 \mathrm{ft})$ in diameter and $7.8 \mathrm{~m}(25.5 \mathrm{ft}) \mathrm{high}$, with a capacity of 208,000 1 $(55,000 \mathrm{gal})$. A11 the tanks are made of a carbon steel liner surrounded by a reinforced concrete shell. They are covered by at least 6 feet of soil, which acts as shielding to minimize radiation exposure to workers. The tanks have instruments to measure the waste level and temperature. They al so have a breather filter for passive ventilation or an exhauster for active ventilation. Air leaving the tanks goes through high-efficiency particulate air filters.

The waste in single-shell tanks is in three general types: sludge, salt cake, and 1 iquid. Sludge is the heavier solids (hydrous metal oxides) left from the neutralization of acid wastes before their transfer to the tanks. 
Salt cake consists of salts left after water evaporates from alkaline waste. Liquids are found both within and on top of the waste.

Interim stabilization means removing liquid to minimize the spread of contamination if the tank leaks. That liquid goes to double-shell tanks. Only tanks with more than 189,0001 (50,000 gal) of drainable liquid, or more than 19,000 1 (5,000 gal) of surface liquid, are being pumped. After they are pumped, the single-shell tanks are isolated, which means they are sealed off so no liquid can get in. This work is presently on hold awaiting revised safety analyses.

Hanford's 28 double-shell tanks contain about 75.7 million liters (20 million gallons) of liquid radioactive waste. These tanks have a second steel wall. The space between the walls is monitored for leaks. Double-shell tanks have been built since 1968, and used since 1970. None have leaked. Although a few tanks were designed for only 20 years of use (most were designed for a 50-year 1 ife), a 50-year life is a more current estimate for all double-shell tanks. If a tank does leak from its primary to secondary liner, the waste in it will be moved to another double-shell tank. The available reserve tank space is estimated to be 12.9 million liters ( 3.4 million gallons). Two ways to increase the reserve space--by grouting some low-level double-shell tank waste, or building new tanks--are being actively pursued.

Recent research shows that more study is needed before more liquid is pumped from the single-shell tanks containing ferrocyanide or large amounts of ignitable materials. We also must reevaluate the risks of concentrating waste in double-shell tanks. Drying out double-shell tank waste may not be beneficial because those tanks are not being pumped to avoid leakage. The drier wastes generate higher temperatures and would be more difficult to retrieve for final disposal.

\section{Tank Waste Safety Issues}

Potentially flammable gases are generated by the decomposing waste in some tanks. Other tanks contain ferrocyanide-nitrate and organic-nitrate mixtures. Evaluating the risks related to these tanks, and remediating them, are complex technical questions. Scenarios include:

- Ignition of organic-nitrate and/or nitrate-ferrocyanide mixtures initiated by the radiolytic heating of dry salt cake (24 tanks)

- Ignition of potentially flammable gases such as hydrogen-air, hydrogen-nitrous oxide, and/or air-organic vapor mixtures (23 tanks)

- Secondary ignition of organic-air and/or organic-nitrate mixtures initiated by the burning of flammable gases ( 8 tanks several of which are also in the flammable gas category)

- Forced water cooling is also necessary for single-shell tank, 241-C-106, which is also considered an unresolved safety issue. 
Almost all of Hanford's waste tanks contain an abundance of oxidants, such as sodium nitrate/sodium nitrite salts. Some also contain more than a ton of potential fuel-oxidizer mixtures, such as ferrocyanide or organic complexant compounds. Storing these wastes safely depends on keeping their temperatures below a flashpoint. Active ventilation and sometimes evaporative cooling is used to control tank temperatures. These temperatures appear to be stable or decreasing, and have been for years.

Work has been done on organic-nitrate reactions, and more work is under way to better define the flashpoint for ferrocyanide--nitrate reactions. We plan to show that in-tank temperature measurements do represent the tank contents, and that these temperatures are kept at least $93^{\circ} \mathrm{C}\left(200^{\circ} \mathrm{F}\right)$ below the $221{ }^{\circ} \mathrm{C}\left(430^{\circ} \mathrm{F}\right)$ we believe is the flashpoint. Please see Section $\mathrm{B} .12$ for more details on our activities on ferrocyanide issues.

The issue of potentially flammable gases concerns 23 tanks (both doubleand single-shell). The gases are nitrous oxide, generated by the breakdown of the organic complexants in the waste, and hydrogen, generated by radiolysis. Normally, the gases rise to the surface, into the empty space above the waste, where they are swept away by the tank's filtered ventilation system.

But in these 23 tanks, a crust has formed on the surface of the waste, and the waste contains dense solids. This combination causes the gases to collect within the waste instead of rising continuously to the surface. These collected gases, which are potentially flammable in certain concentrations, tend to be released through periodic "ventings" rather than continuously. One tank, known as Tank 101-SY, is of particular concern because it shows the largest accumulation of gases before periodic venting.

We need to know the composition of the waste in these tanks before remediation options can be evaluated. Options include diluting and/or stirring the wastes so the gases they generate are released continuously and do not build up. In the meantime, we've reduced the chance of ignition through several steps, such as the use of spark-resistant tools in the area of tank 101-SY. Also, we're making sure the tanks are ventilated enough to keep the hydrogen-nitrous oxide mixture from becoming dangerously concentrated.

The gas buildup issue, which is different from the concern about those tanks containing ferrocyanide, was identified in late 1989 by scientists and engineers from Westinghouse Hanford. They have since presented DOE with a plan to characterize the contents of tank 101-SY and remediate the problem. Several independent review groups, including the Defense Nuclear Facilities Safety Board, Advisory Committee on Nuclear Facility Safety, and a team from DOE-HQ have agreed that tank $101-S Y$ does not constitute an imminent danger.

Ammonium nitrate is not a waste tank safety issue, despite its explosive potential, because very little ammonium nitrate can exist in alkaline aqueous wastes. Some ammonium nitrate is found in offgas lines, but again, because only small amounts are involved, it does not appear to present a hazard. Likewise, the risk of fires or explosions from solvent vapors appears small. 


\section{C.14 - OFFICE OF SAMPLE MANAGEMENT ROLE IN CLEANUP}

The Westinghouse Hanford Office of Sample Management was formed in February 1989 to serve as an interface organization between Hanford programs and the analytical laboratories. In this role, the Office of Sample Management coordinates analytical services for onsite cleanup programs and operations.

Part of this responsibility is to assess projected sample loads and analytical requirements. This includes reviewing work plans and sampling plans. Based on the assessment, the Office of Sample Management may get additional laboratory services if they are needed. It prepares statements of work to bring the laboratories on board and assumes administrative functions for the contract. It also has the lead role in regularly scheduled laboratory audits to ensure that performance is acceptable and within requirements of the contract. The Office of Sample Management is developing a program that will include periodic submittal of performance evaluation samples and comparison of results.

When the cleanup. process generates samples, the Office of Sample Management is responsible for finding an available laboratory. It is also responsible for resolving and communicating any questions that arise between the field teams and the laboratory. When required, the Office of Sample Management coordinates sampling team support. The office has a database called SAMTRAC that tracks information about the shipment, receipt, and analysis of samples. The database can produce reports for program personnel. Laboratories transmit all sample results to Westinghouse Hanford through the Office of Sample Management. It verifies results for completeness; it validates them in accordance with Office of Sample Management procedures, then copies and transmits the results to the appropriate program personnel. The office serves as a temporary retention center for the Record Copy data.

The Office of Sample Management is involved in a research and developmen $i$ function for new analytical methods and laboratory upgrades for onsite facilities. The office uses a computer-based system that links different functions within the laboratories. Office of Sample Management staff participate in conferences to get insight for future requirements for laboratory operation and development.

In addition to working with all of the internal organizations involved in the cleanup effort, the Office of Sample Management frequently works with the $D O E, E P A$, and Ecology in performing these functions. 


\section{15 - VENT LINES ON COLUMBIA RIVER ISLAND}

The DOE-RL conducted a comprehensive examination of the bank of the Hanford Reach of the Columbia River. The examination revealed that process effluent 1 ines from the 100-D Reactor had vent pipes from the 1 ine extending above the surface of an island. The line was placed through the island to discharge to the main channel of the river. About 40 short $(0.3-$ to $1-m$ [1- to 3-ft]) small-diameter (2.5- to 5-cm [1- to 2-in.]) vent pipes extend above the low-water leve?. These pipes showed contamination ranging from 1,000 to $6,000 \mathrm{cpm}$. The pipes are part of the 100-D outfall pipeline, which discharged reactor effluent to ihe river when the reactor was operated.

Westinghouse Hanford plans to remove the vent pipes by excavating about 15 to $30 \mathrm{~cm}$ (6 to $12 \mathrm{in.}$ ), cutting off the pipes, capping them, and refilling the holes. The vent pipes are on a portion of the island below the high-water mark, which makes a 11 excavations (and many other activities) subject to approval by the U.S. Army Corps of Engineers. The volume of excavated material normally would be covered by an existing nationwide permit, which requires only concurrence from the Corps of Engineers.

However, nationwide permits are not applicable to (among other things) rivers officially designated as study rivers under the Wild and Scenic Rivers Act. The Hanford Reach is an official study river and therefore DOE must submit a separate permit application. In addition, DOE must notify the National Park Service (due to the activity occurring within $1 / 4 \mathrm{mi}(0.4 \mathrm{~km})$ of the Hanford Reach) and the Washington State Department of Fisheries. The permit application and letter of notification are in review at DOE-RL.

Discussions between DOE-RL and Westinghouse Hanford are under way to determine what, if any, other documentation will be required for this activity. 
This page intentionally left blank. 


\section{D.1 - WASTE MANAGEMENT UNITS}

\section{D.1.1 NUMBER OF UNITS}

The following provides information on the relationship between "total" waste sites, waste management units, and the environmental restoration operable units.

Total entries in the Waste Information

Data System

Minus unplanned releases into engineered waste units (these releases are not considered as separate waste management units)

Total waste management units

Minus those waste management units not addressed by the Tri-Party Agreement (includes surplus facilities and other contaminated structures/areas, such as waste staging areas)

Total waste management units addressed in Tri-Party Agreement

Minus TSD units [i.e., regulated under units

Total units assigned to operable units to be addressed by the Environmental

Restoration Program

Minus TSD units [i.e., regulated under RCRA 3005(e)] included in operable units (e.g., single-shell tanks)

Total past-practice units [i.e., regulated = under Superfund or RCRA $3004(u)]$.
$=1,528$ (approximately 1,530 )

$-\quad 137$

$=1,391$ (approximately 1,400)

123

$=1,268$ (approximately 1,270)

$-122$

$=1,146$ (approximately 1,150 ) 926 (approximately 930)

Source: Hanford Site Waste Information Data System as of $05 / 17 / 91$. 


\section{D.1.2 CATEGORIES OF UNITS}

$\begin{array}{cccc}\text { Number of waste units } & \text { All waste units } & \begin{array}{c}\text { Environmental } \\ \text { restoration units }\end{array} \\ \text { Nonhazardous } & 174 & & 165 \\ \text { Hazardous } & 134 & 96 \\ \text { Radioactive } & 133 & 105 \\ \text { Mixed } & \frac{950}{1,391} & \frac{782}{1,146}\end{array}$

\section{Major types of waste units}

Single-shell tanks

Double-shell tanks

Cribs and drain fields

Trenches

Ponds

Ditches

Reverse wells

French drains

Engineered liquid disposai unit sum (excluding single- and double-shell

\begin{tabular}{cccc} 
Active & Inactive & Waste volume \\
\cline { 1 - 1 } 0 & $149 *$ & $36,778,000 \mathrm{gal}$ \\
28 & 0 & $23,418,000 \mathrm{gal}$ \\
16 & 115 & \\
1 & 88 & \\
13 & 18 & \\
8 & 13 & \\
0 & 11 & \\
21 & 46 & \\
57 & 284
\end{tabular}
tanks)

Spills

Burial grounds

Landfills

Demolition and inert 1 andfills

$\begin{array}{rr}0 & 229 \\ 9 & 68 \\ 2 & 10 \\ 3 & 2\end{array}$

* Note: Single-shell tanks are considered as RCRA active units by Ecology.

Number of past-practict operable units as of $02 / 89$

$\begin{array}{rr}100 \text { Area } & 22 \\ 200 \text { Area } & 43 \\ 300 \text { Area } & 5 \\ 1100 \text { Area } & \underline{4} \\ \text { TOTAL } & 74\end{array}$

(Does not include four groundwater operable units)

Source: Hanford Site waste information Data System, as of $05 / 17 / 91$. 


\section{D.2 - RADIOACTIVE WASTE INVENTORIES}

The information for Hanford Site radioactive waste volumes and radioactivity reported for the 1990 Integrated Database is as follows:

\section{Total Volume of Waste}

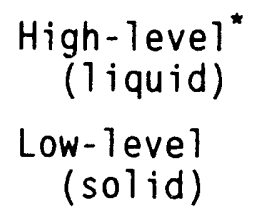

$2.45 E+05 \mathrm{~m}^{3}$ (64.7 million gallons)

$5.64 \mathrm{E}+05 \mathrm{~m}^{3}$ $\left(737,000 \mathrm{yd}^{3}\right)$

TRU:

Buried

Contaminated soil

$$
\text { Volume }
$$
Mass of TRU nuclides

Volume

Mass of TRU
nuclides

Retrievably stored

Volume
Mass of TRU nuclides

Low-level mixed waste

$$
\text { Volume }{ }^{a}
$$

Mass
$1.09 \mathrm{E}+05 \mathrm{~m}^{3}$ $\left(143,000 \mathrm{yd}^{3}\right)$

$$
\begin{gathered}
346 \mathrm{~kg} \\
(763 \mathrm{lb})
\end{gathered}
$$

$31,960 \mathrm{~m}^{3}$

$190.2 \mathrm{~kg}$

(419 1b)

\section{$1.02 E+04 \mathrm{~m}^{3}$} $\left(13,312 \mathrm{yd}^{3}\right)$

$$
\begin{gathered}
476 \mathrm{~kg} \\
(1,049 \mathrm{ib}) \\
2,450 \mathrm{~m}^{3} \\
\left(3,205 \mathrm{yd}^{3}\right)
\end{gathered}
$$

$5,304,000 \mathrm{~kg}$

$(5,847$ tons $)$

${ }^{a}$ Volume is based on an average density of $2,162 \mathrm{~kg} / \mathrm{m}^{3}$ (135 $\mathrm{lb} / \mathrm{ft}^{3}$ ) after processing.

\section{Total Radioactivity of Waste}
High-level
Low- Tevel
4.16 E+08 Ci
(1 iquid)
TRU

$$
\begin{array}{lll}
5.32 \mathrm{E}+06 \mathrm{Ci} & \text { (solid) } \\
2.38 \mathrm{E}+05 \mathrm{Ci} & \text { (solid) }
\end{array}
$$

"Hanford tanks contain high-level, low-level, and TRU wastes. However, in the storage mode, all tanks are managed as if they contain HLW and therefore are included in the HLW inventory. 
Charts comparing Hanford Site radioactive waste volume and radioactivity with other sites', are shown in Figures D-1 through D-4.

Cesium and Strontium Capsules

Cesium capsules $-1,350$

Strontium capsules - 597

$1.19 \mathrm{E}+08 \mathrm{Ci}$

$5.45 \mathrm{E}+07 \mathrm{Ci}$

This includes 1,350 cesium capsules with $1.19 \mathrm{E}+08 \mathrm{Ci}$ (solid) and 597 strontium capsules with $5.45 \mathrm{E}+07 \mathrm{Ci}$ (solid). In 1985, 1,577 cesium and 640 strontium capsules were in storage. A number of capsules were leased and have not yet been returned to the Hanford Site. 
Figure D-1. High-Level Waste Comparison: Hanford to All DOE Sites.

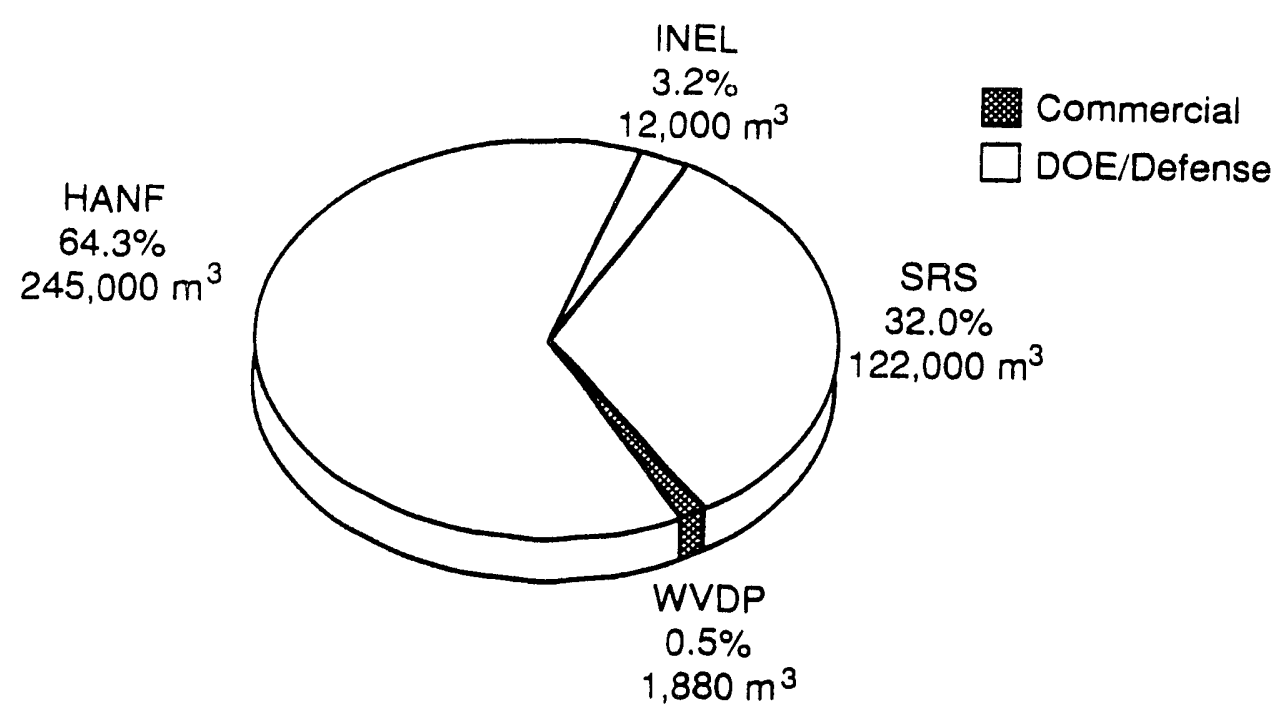

Total Volume of High-Level Waste

R9004237.2a

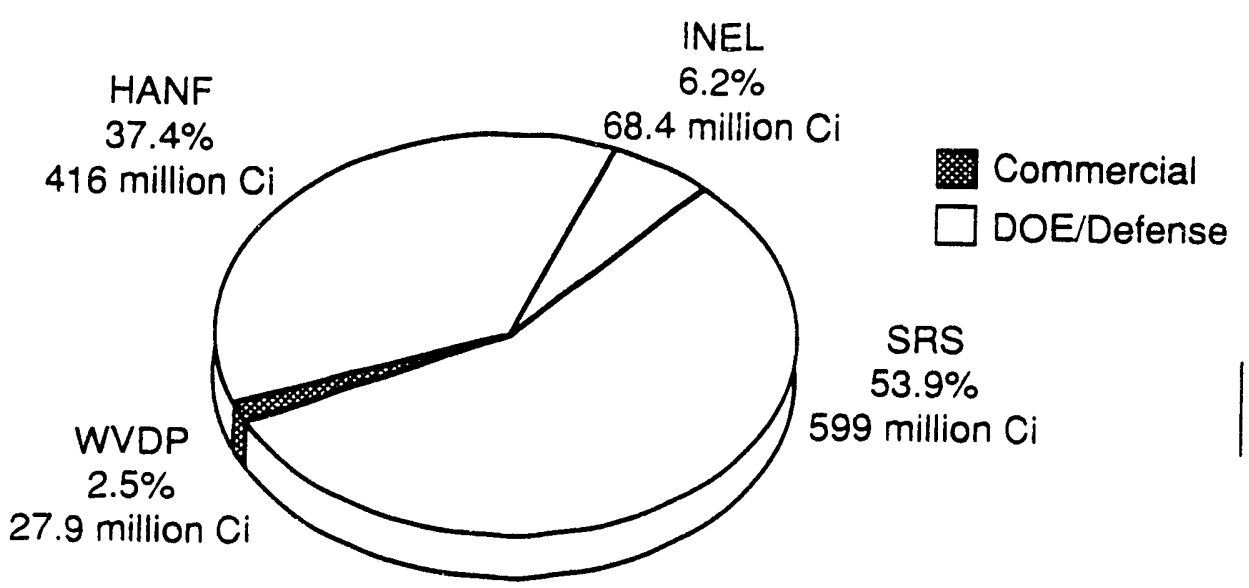

Total Radioactivity of High-Level Waste

HANF The Hanford Site

INEL Idaho National Engineering Laboratory

SRS Savannah River Site

WVDP West Valley Demonstration Project

Note: Information is from Integrated Data Base for 1990. 
Figure D-2. Low-Level Waste Comparison: Hanford to All DOE Sites.

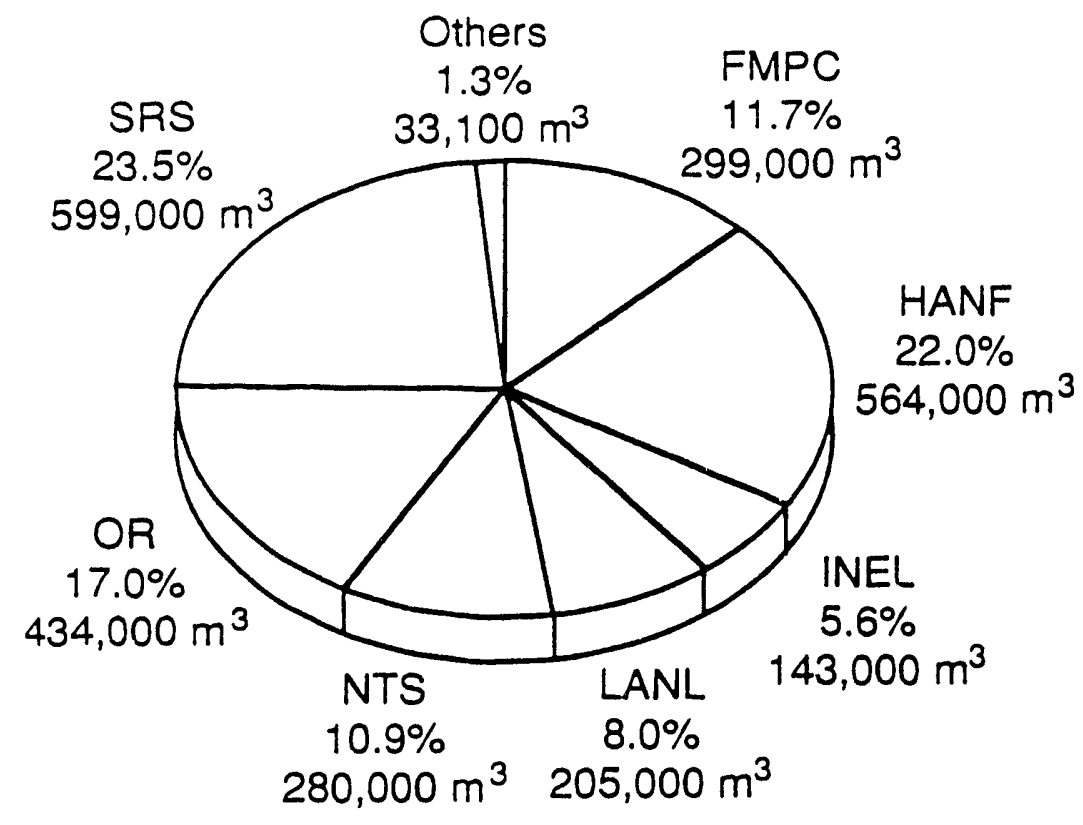

\title{
Total Volume Buried Low-Level Waste
}

\author{
HANF The Hanford Site \\ INEL Idaho National Engineering Laboratory \\ LANL Los Alamos National Laboratory \\ NTS Nevada Test Site \\ OR Oak Ridge Complex: includes Oak Ridge National \\ Laboratory, Gaseous Diffusion Plant, and "Y-12" Plant \\ SRS Savannah River Site \\ FMPC Feed Materials Production Center (Fernald, Ohio)
}

Note: Information is from Integrated Data Base for 1990. 
Figure D-3. Buried Transuranic Waste Comparison: Hanford to All DOE Sites.

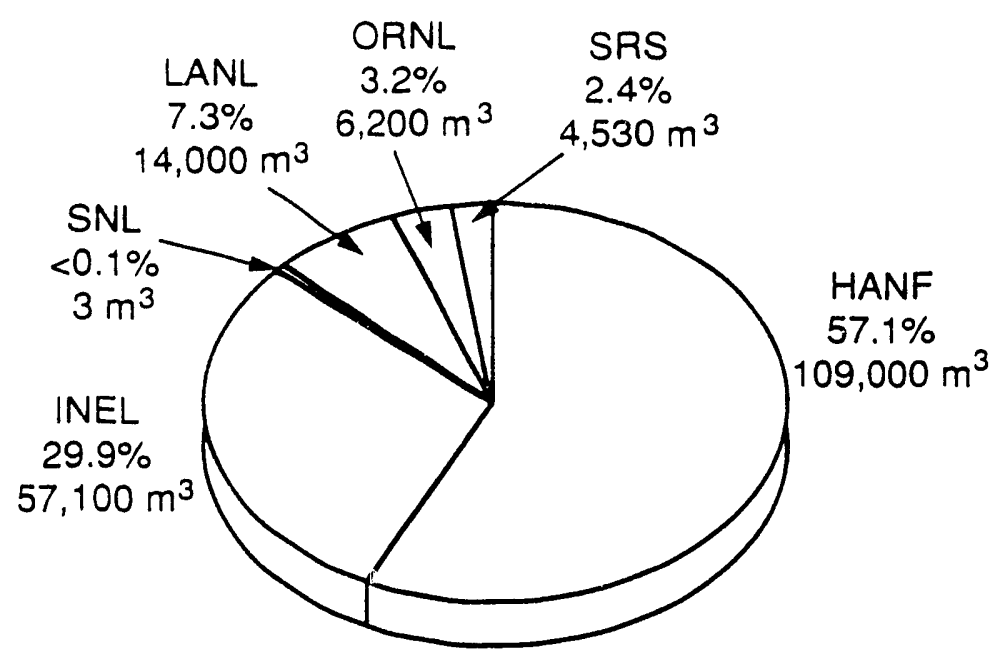

Total Volume Buried Transuranic Waste

R9004237.3a

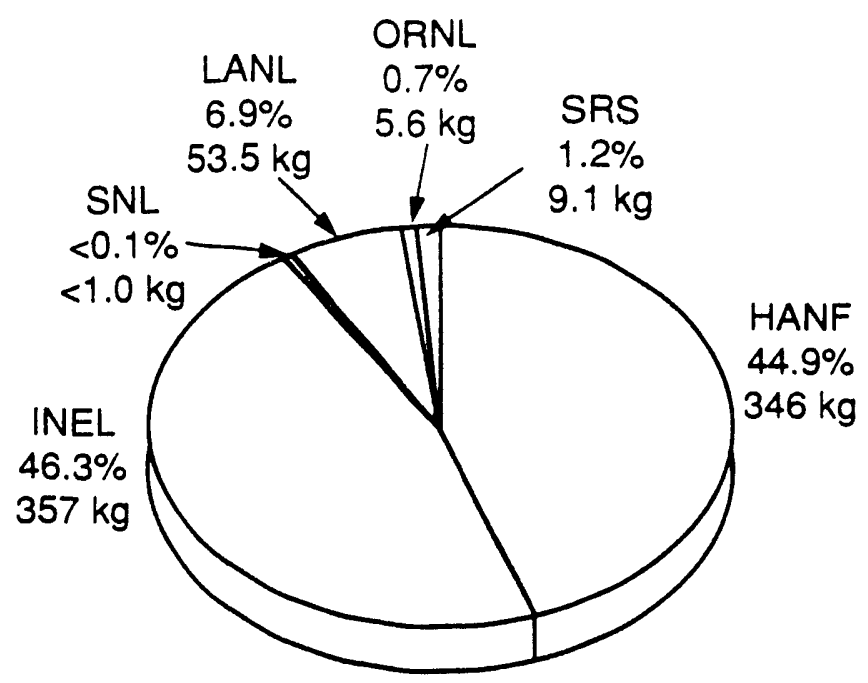

Total Mass Buried Transuranic Waste
HANF The Hanford Site
INEL Idaho National Engineering Laboratory
LANL Los Alamos National Laboratory
ORNL Oak Ridge National Laboratory
SNL Sandia National Laboratory
SRS Savannah River Site

Note: Information is from Integrated Data Base for 1990. 
Figure D-4. Stored Transuranic Waste Comparison: Hanford to All DOE Sites.

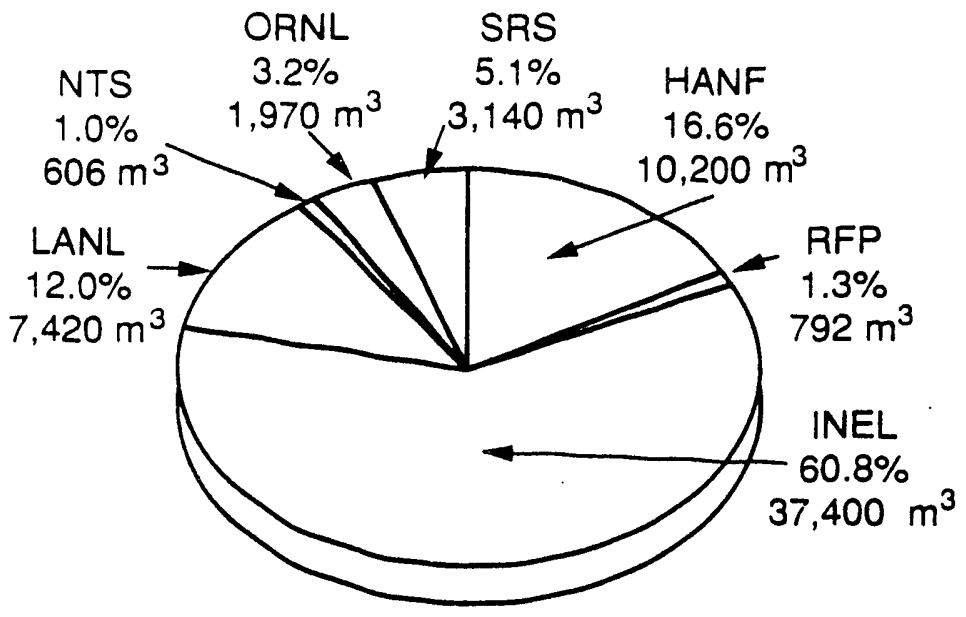

Total Volume Stored Transuranic Waste

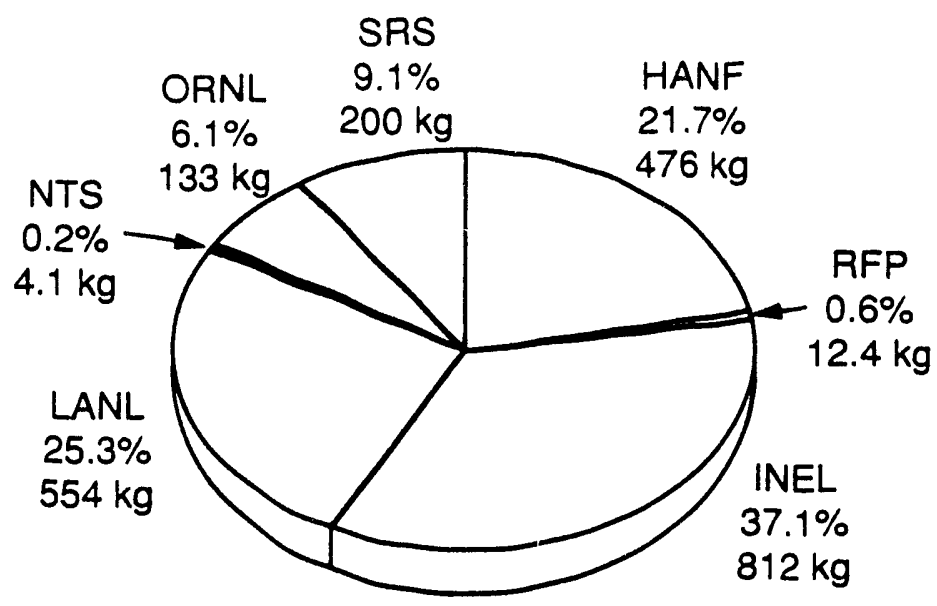

Total Mass Stored Transuranic Waste
HANF The Hanford Site
INEL Idaho National Engineering Laboratory
LANL Los Alamos National Laboratory
NTS Nevada Test Site
ORNL Oak Ridge National Laboratory
RFP Rocky Flats Plant
SRS Savannah River Site

Note: Information is from Integrated Data Base for 1990. 


\section{3 - WASTE TANK STATUS}

- Number of waste tanks

- 149 single-shell tanks ${ }^{1}$

- 28 double-shell tanks.

- Number of tanks that are assumed leakers

- 66 single-shell tanks ${ }^{2}$

- 0 double-shell tanks.

- Chronology of single-shell tank leaks

- 1959 first tanks reported leaking (106-TY, 101-U)

- 1988 latest tanks reported leaking (102-AX, 201-C, 202-C, $204-C, 104-5 X)$

- 1973 largest estimated leak (106-T, 115,000 gal). ${ }^{3}$

${ }^{1}$ All single-shell tanks were removed from service in November 1980 . No waste is being transferred among the tanks and no new waste is being added.

${ }^{2}$ There was a question whether Tank 241-C-103 may have started leaking in spring 1991 because of a liquid-level decrease (no change however, in dry well). Further evaluation concluded the liquid-level decrease was due to evaporation.

${ }^{3}$ This estimate does not include the cooling water sprayed into Tank 241-A-105. Reports have surfaced about cooling water added to and believed leaked from this l-million gallon tank. Cooling water was added to Tank 105-A after it was declared a leaking tank in 1963. The tank initially leaked $5,000 \mathrm{gal}$ of radioactive waste; a revised estimate is being determined.

Water was added to the tank to control its temperature. During the 10 years that cooling was required, 250,000- to 1 -million gallons were added. This volume range is a refinement of earlier estimates, reported in the news media, in the range of 1 - to 1.5-million gallons. Water additions ceased in December 1978 after sampling for hydrogen gas beneath the bulged bottom showed negative results. Preliminary estimates indicate that between 50,000 and $960,000 \mathrm{gal}$ of cooling water leaked to the ground. An estimated 335,000 to 366,500 gal of water loss is accounted for by evaporation. 
- Interim stabilization program for single-shell tanks

- 105 single-shell tanks stabilized

- Stabilization program to be completed in 1996.5

- Isolation program for single-shell tanks

- 95 single-shell tanks interim isolated ${ }^{6}$

- 56 single-shell tanks partial interim isolated. ${ }^{7}$

- Total radioactive waste leakage volume

- Previously published leak estimates (38 tanks)--542,000 gal

- Leaks where loss determined by measurement ( 9 tanks).35,000 gal

- Leaks statistically determined median (19 tanks)--163,000 gal

- Total volume--740,000 gal.3

"The term 'interim stabilized' is defined as a tank that contains less than $50,000 \mathrm{gal}$ of interstitial 1 iquid and less than 5,000 gal of supernatant liquid.

${ }^{5}$ Interim stabilization activities began before FY 1978. The first single-shell tanks were pumped in FY 1979. Of those 105 tanks currently designated interim stabilized, 28 have been jet pumped, 20 have been submersible pumped, and 57 were stabilized administratively. Approximately 3.5 -million gallons of liquid have been removed in the salt well program. The remaining 44 tanks are currently scheduled to be interim stabilized by FY 1996. Estimated cost of pumping the remaining tanks is $\$ 78$ million. Four of five tanks scheduled for interim stabilization in FY 1990 were completed. The delay resulted from pumping restrictions because of unresolved safety questions about ferrocyanide in the tanks.

${ }^{6}$ Interim isolated is the administrative designation reflecting completion of the physical effort required to minimize the addition of liquids into an inactive storage tank, process vault, sump, catch tank, or diversion box.

${ }^{7}$ Partial interim isolation is the administrative designation reflecting the completion of the physical effort required for interim isolation, except for isolation of risers and piping required for jet pumping or for other methods of stabilization. 


\section{D.4 - iOO AÑE. SHALLOW LAND BURIAL OF RADIOACTIVE LOW-LEVEL WASTE}

From 1944 through 1973, direct shallow land burial in the 100 Areas of the Hanford Site was used to dispose of low-level radioactive wastes associated with reactor operations. The wastes were buried in 28 separate locations. Most waste generated from routine reactor operations was placed in seven primary burial grounds, one for $100-\mathrm{KE} / \mathrm{KW}$ and one for each of the six other reactors $(100-B,-C,-D,-D R,-F$, and $-H)$. The remaining 21 burial grounds were associated with special programs such as retention basin repair, effluent line modifications, thimble removal, and special irradiations.

The major radioactive wastes in the burial grounds are 385 metric tons of aluminum spacers, 1,000 metric tons of lead-cadmium pieces, boron splines (56.7 metric tons aluminum and 7.7 metric tons boron), carbon materials ( $1,040 \mathrm{~kg}$ graphite and $5,972 \mathrm{~kg}$ of graphite-contaminated desiccant), 241 metric tons of aluminum process tubes, and 268 metric tons of lead. A total of 144 metric tons of miscellaneous waste includes gunbarrels, thimbles, control rods, nozzles, pigtails, and cadmium sheets. (Descriptions of these miscellaneous materials can be found in Estimates of Solid Waste Buried in 100 Area Burial Grounds, WHC-EP-0087, October 1987, Westinghouse Hanford Company.)

\section{Aluminum Spacers}

Aluminum spacers were used to center the reactor fuel column in the process tube and to prevent the fuel elements from flushing to the rear tube cap during high flow (operating) periods. The estimated number of spacers used at the eight single-pass cooled reactors is 1,700,000 or the equivalent of 385 metric tons of aluminum.

Nuclides formed by neutron activation of iron, nickel, and cobalt contained in the aluminum are of interest for radionuclides inventory estimates. Radionuclides of other elements are either stable or have such short half-lives that they have decayed to essentially zero.

\section{Lead-Cadmium Pieces}

The lead-cadmium alloy used as neutron 'poison' was in the form of a solid cylindrical rod approximately $3.6 \mathrm{~cm}$ in diameter and $15.4 \mathrm{~cm}$ long. The rod was sealed in an aluminum can with a wall thickness of $1 \mathrm{~mm}$. The alloy contained 96 percent lead and 3 to 4 percent cadmium. of the estimated 1,000 metric tons of lead-cadmiun pieces disposed of in the burial grounds, 961 metric tons are lead and 40 metric tons are cadmium.

All reactors used lead-cadmium for 'total control' to ensure that the reactor remained subcritical during extended outages. From 1944 through 1960, lead-cadmium pieces were the primary supplemental control device used during 
reactor startups to override the reactivity transients (principally xenon burnout) until newly produced iodine converted to xenon to reach

'equilibrium.

\section{Boron Splines}

Splines were about $1.3 \mathrm{~cm}(1 / 2 \mathrm{in.})$ wide, $0.16 \mathrm{~cm}(1 / 16 \mathrm{in}$.$) thick, and$ $9.1 \mathrm{~m}(30 \mathrm{ft})$ long. They were made of approximately 12 percent boron and 88 percent aluminum. They were inserted through special nozzles into the process tubes and underneath the fuel elements. Splines were used in the reactor to assist in control of the reactivity transient during startup and to 'flatten' the neutron flux distribution for optimum production. They replaced the lead-cadmium pieces used to provide supplemental poison from 1960 on.

The estimated number of boron splines disposed of in the 100 Area solid waste burial grounds is 142,236 , composed of 56 metric tons of aluminum and 7.7 metric tons of boron. The only radionuclide of interest from the irradiation of splines is cobalt-60 from the cobalt impurity in the aluminum.

\section{Carbon Materials}

Graphite containing carbon-14 was removed from the reactor blocks during replacement of corroded aluminum process tubes and from overboring for larger diameter tubes. In the burial grounds are $1,043 \mathrm{~kg}$ of this graphite. A second source of carbon-14 was the disposal of depleted desiccant (silica ge1) used in the 115 Building drying towers for the reactor gas system. The desiccant collected small quantities of fine graphite from recirculation of the reactor gas. Desiccant disposed of in the burial grounds amounted to $5,973 \mathrm{~kg}$. The radionuclide inventory of the graphite contributes only a few curies to the total inventory.

\section{Aluminum Process Tubes}

Most process tubes 'were fabricated from aluminum alloy and were about $12.2 \mathrm{~m}$ long with an inside diameter of $4.49 \mathrm{~cm}$ and a wall thickness of $0.125 \mathrm{~cm}$. The tubes penetrated the reactor block horizontally with the center $7.6 \mathrm{~m}$ in the active zone of the reactor. Extensive replacement of aluminum process tubes became necessary because of internal corrosion (later a reduction of the coolant pH mitigated the corrosion problem). A lesser number of process tubes were replaced because of fuel element ruptures creating 'stuck charges.' Also, about 4,800 17 uminum process tubes were replaced with zirconium process tubes in the KE ard KW Reactors. The estimated number of aluminum process tubes disposed of in the 100 Area burial grounds is 28,000 tubes containing 241 metric tons of aluminum. 
Lead

Besides the lead-cadmium pieces (95.88 percent lead) used for reactivity control, most of the lead buried in the 100 Area burial grounds is in four forms. These forms include standard $11.3 \mathrm{~kg}$ lead bricks; lead sheets that varied in thickness from 1.3 to $0.158 \mathrm{~cm}$; lead used in shipping, handling, and shielding casks; and lead wool. Estimated quantities of lead in these forms are as follows:

- Lead bricks

- Lead sheets

- Shipping, handling, and shielding casks

- Lead wool

TOTAL

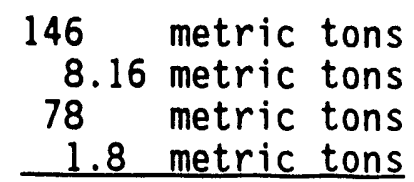

234 metric tons.

This estimate does not include lead buried during the tritium separation program. Lead disposed of in burial grounds from this program is estimated separately.

\section{Miscellaneous Waste}

Several different reactor components were repiaced and disposed of in the 100 Area burial grounds during routine maintenance and from special production improvement programs. The components include gunbarrels, thimbles, horizontal control rods, vertical safety rods, nozzles and pigtails, thermocouple wire, and reactor tools. A total of 144 metric tons is assigned to this category of waste.

\section{Tritium Separation Program}

A special tritium separation program was operated at 100-B Area from the late 1940's until 1952 ( $P-10$ Project). Tritium was produced in the reactor by irradiating an aluminum-clad lithium target. A pilot separation line was set up in the 108-B Building to extract tritium from the irradiated lithium material. A number of materials were buried as waste from this process:

- Spent lithium-aluminum alloy

- Lead from pots

- Mercury

- Glass from glass line

$\begin{array}{rr}96,000 \mathrm{lb} & 43,400 \mathrm{~kg} \\ 77,000 \mathrm{lb} & 34,800 \mathrm{~kg} \\ 2,100 \mathrm{ib} & 950 \mathrm{~kg} \\ 2,500 \mathrm{lb} & 1,131 \mathrm{~kg} \\ 6,800 \mathrm{lb} & 3,077 \mathrm{~kg} \\ 3,000 \mathrm{lb} . & 1,357 \mathrm{~kg}\end{array}$

- Aluminum cladding

- Palladium

3,00016 .

$1,357 \mathrm{~kg}$

The contribution of radionuclides to the burial grounds from the tritium separations is $14,800 \mathrm{Ci}$. 


\section{Biology Laboratory Disposal}

About 7,600 $\mathrm{yd}^{3}$ of sawdust from the dog kennels and swine pens, containing traces of strontium-90 and some plutonium-239, were deposited outside the 100-F Area. This sawdust was covered with a $1.22 \mathrm{~m}$ layer of soil. 


\section{D.5 - 200 AREA SHALLOW LAND BURIAL OF RADIOACTIVE LOW-LEVEL WASTE}

Hanford Site contractors have buried radioactive solid waste directly into shallow land in the 200 Areas since 1944. They have disposed of waste from reactor operations, chemical processing and separations, research and development activities, and other DOE programs in both the 200 East and West burial grounds. Contamination in these wastes consists of fission products, induced activation products, and TRU isotopes. Solid wastes originate from both onsite and offsite DOE sponsored programs and facilities.

The 200 Area burial grounds have received many types of waste. Both lowlevel waste and TRU unsegregated wastes were disposed of between 1944 and 1970. Since 1970, the TRU wastes have been segregated and placed in areas designated as Retrievable Storage Units. At present, TRU wastes are stored in the 224-T Building and the Central Waste Complex.

Former burial ground activities are described in ERDA-1538, Final Environmental Statement Hanford Waste Management Operations. Wastes with potentially hazardous constituents such as lead or carbon tetrachloride have been buried in the burial grounds or placed in the Retrievable Storage Units. In 1985, we began desianating radioactive mixed wastes as dangerous waste. Since 1987, with the exception of the submarine reactor compartments and the Shippingport Reactor Pressure Vessel, all mixed wastes have been stored in aboveground RCRA-permitted facilities.

Waste volumes are tracked on the Richland Solid Waste Information Management System. Total radioactive solid waste volumes for the burial grounds exceed 14-million cubic feet. This volume of waste corresponds to more than a million curies of radioactivity. We report waste volumes annually to DOE's national integrated database.

Portions of the 200 Area burial grounds are permitted under DOE/RL 88-20, Low-Level Burial Grounds Dangerous Waste Permit Application. Under this permit certain burial grounds are classified as landfills (D81). Porticns of these burial grounds designated as Retrievable Storage Units are classified as container storage.

\section{Waste Acceptance Criteria}

Waste acceptance criteria for storage or disposal of low-level waste is contained in WHC-EP-0063-2, Hanford Site Radioactive Solid Waste Acceptance criteria. This document describes the characterization, packaging, waste form labe'ing, marking, and documentation requirements for radioactive waste dispusal. 


\section{Low-Level Waste Disposal}

Numerous waste forms and packages have been disposed to the burial grounds. Waste forins might consist of ion exchange resins; asbestos; classified waste packages; contaminated heavy equipment, such as craries and grade-alls; wastes such as pumps from tank farms; various process equipment, such as piping and valves; laboratory wastes; hot cell wastes; and miscellaneous contaminated items, such as paper, rubber, plastic, glass, etc,. Packages used to dispose of waste range from self-contained items, plastic wrap, carlboard boxes, or 55-gallon drums to larger metal boxes, concrete casks, and composite material containers. With the exception of the submarine reactor compartments, the Shippingport reactor pressure vesse1, and Surrey steam generator, the largest waste container used is the multi-purpose disposal box $(12 \mathrm{ft} \times 12 \mathrm{ft} \times 30 \mathrm{ft})$. Various specific waste forms and practices are described below.

\section{Retrievable Storage Units}

Since 1970, TRU-contaminated and suspect TRU wastes have been placed in areas designated as retrievable storage units. In addition, since the mid-1980's, certain radioactive wastes (such as contaminated liquid organic) were placed there, too. Currently, TRU waste generation is covered by TRU waste certification plans and stored in abovegrade buildings such as the 224-T Building and the Central Waste Complex. During the past 20 years, we have used various designs for the retrievable storage units. A typical unit might consist of an asphalt pad in the bottom of the waste trench. Waste drums were stacked four drums high with fire retardart plywood between the layers of drums. The entire drum array was surrounced by a plastic tarp and covered by fire retardant plywood.

\section{Caissons}

Waste caissons, described in DOE/RL 88-20, primarily consist of a belowgrade silo. Caissons were used to dispose of high-activity low-level waste and to store high-activity TRU wastes. The high-activity TRU wastes will be retrieved for offsite disposal. The high-activity waste was remotely placed in the caissons.

\section{Submarine Reactor Compartments}

Submarine reactor compartments are disposed of in Trench 94 of the 218-E-12B burial ground. See Section C.9.

\section{Shippingport Reactor Pressure Vessel}

The defueled reactor pressure vessel from the Shippingport commercial reactor has been disposed of in irench 14 of the 218-W-4B burial ground. This waste consists of concrete, carbon steel, and a small quantity of lead. It is 
considered mixed waste because of the lead. A steam generator from the Surrey reactor is also buried in this trench.

\section{Animal Wastes}

A small quantity of animal wastes consisting of bedding, feces, urine, absorbent, carcasses, etc., have been disposed of in the burial grounds.

\section{Low-Level Mixed Waste Disposal}

Plans call for shallow land disposal of low-level mixed wastes in the 218-W-5 burial ground. Under Project W-025, a double-lined leachate collection trench will be constructed. When this project is completed, wastes meeting the DOE, EPA, and Washington State acceptance criteria will be buried in this trench.

\section{Spent Fuel Storage}

At present, 75 containers of spent fuel (approximately $140 \mathrm{~m}^{3}$ $\left[5,000 \mathrm{ft}^{3}\right]$ ) are in areas designated as TRU-retrievable storage in the lowlevel burial grounds. The spent fuel contains more than $500,000 \mathrm{Ci}$ of radioactivity. The fuel is stored in concrete or metal containers. Plans call for the fuel to be shipped offsite for disposal in a geologic repository. 


\section{D.6 - HAZARDOUS WASTE INVENTORIES}

Hazardous waste is generated in the normal course of operations at the Hanford Site. All nonradioactive hazardous wastes are accumulated at the source of generation. There it is packaged and transported to be recycled, stored at the 616 Central Storage Facility Building, or shipped directly offsite. All these wastes are sent offsite to commercial hazardous waste handling facilities for treatment and ultimate disposal.

Radioactive wastes that are also hazardous are called mixed wastes and are accumulated at the source of generation. There they are packaged and transported to the Central Waste Complex for storage awaiting ultimate treatment and disposal on site.

The amounts of hazardous waste generated declined significantly in 1990 compared with 1489. This is due to concerted waste reduction efforts and a process change (ceasing to use the demineralizer at $N$ Reactor). The amounts of radioactive mixed waste increased slightly in the same period. The comparative amounts for the two periods are given below.

$1989(\mathrm{~kg}) \quad \underline{1990(\mathrm{~kg})}$

Containerized:

Hazardous waste

421,923

143,441

Radioactive mixed waste

719,659

$983,06 i$

Liquid:

Hazardous waste

$65,986,686$

514,763

Radioactive mixed waste

$5,955,300$

$6,456,087$ 


\section{D.7 - CONTAMINATED FACILITIES}

At present, 140 facilities at Hanford are designated as surplus or excess. They are scheduled for demolition. This inventory includes 114 contaminated facilities and 26 non-contaminated facilities. The number of surplus facilities varies based on demolition work completed, the changing condition of existing facilities, and the Hanford Site mission. As program missions change at Hanford (for example, cold standby of the $\mathrm{N}$ Reactor), facilities associated with old missions are available for reuse or declared surplus. Surplus facilities are maintained in an environmentally safe condition until they are demolished.

Demolition requirements and techniques vary based on the type and condition of the facility, i.e., contaminated facilities requires some type of demolition and decommissioning versus conventional demolition. The Hanford Surplus Facilities Program is responsible for monitoring the overall inventory of surplus facilities and setting the priority for decommissioning and/or demolition. 


\section{D.8 - CONTAMINATED SOIL AND GROUNDWATER}

\section{D.8.1 SOIL AND GROUNDWATER}

It is very difficult to quote hard and fast figures for groundwater and soil contamination. This is due to several factors. Cleanup is ongoing and volumes change due to these cleanup measures. Also, we handle our current waste differently due to new restrictions. The definitions of the environmental laws and regulations change, most often becoming more restrictive, thus increasing the volume of soil and groundwater deemed contaminated.

Most of the figures quoted are estimates and cannot be firm until the characterization is complete. It is estimated that there are $230,000,000$ banked cubic yards of contaminated soil on the Hanford Site. This equates to approximately $386,400,000$ tons. There are no estimates area by area, but several projects on site have projected their contaminated soils:

$$
\begin{array}{lr}
1100-E M-1 & 50 \text { cubic yards } \\
200-B P-1 & 90,000 \text { cubic yards } \\
316-5 \text { Process Trenches } & 3,000 \text { cubic yards } \\
618-9 \text { Burial Ground -. there is no way of knowing until excavation } \\
\text { is complete. }
\end{array}
$$

The 200 West Area carbon tetrachloride plume affects the groundwater around the Plutonium Finishing Plant. The extent of the carbon tetrachloride contamination is estimated to affect greater than seven square miles of the groundwater in the 210 Area. plumes.

See Figures B-2 and B-4 for recent tritium and nitrates groundwater

\section{D.8.2 OUTDOOR RADIATION AREAS}

Al1 radioactive burial grounds, cribs, trenches, ditches, retention basins, and unplanned release sites are routinely surveyed. The surveys are performed at least annually, but may be done quarterly or semi-annually.

Radiological survey reports are shared with Westinghouse Hanford's Environmental Assurance. This group tracks, trends, and reports environmental radiological information in the Quarterly Environmental Radiological Survey Summary and in the Environmental Surveillance Annual Report.

The number of surface contaminated acres varies. The number is not constant because there is a continuing effort to clean, stabilize, or remedy known contaminated areas while new areas of contamination are continuing to be identified.

Newly identified contamination may be from contamination migration (wind blown or biological intrusion) or changing radiological criteria. 

1 mremihr.

We estimate that 80 percent of the surface contamination is less than

Contaminated areas are posted as "Surface Contamination Area" (see Section A.14), "Radiologically Controlled Area," or "Underground Radioactive Material." Radiologically controlled areas are large posted areas with a high potential for encountering speck contamination. Surface contamination areas have more widespread contamination. "Underground radioactive material" signs mark cribs, burial grounds, and covered trenches and ponds. If an area has surface as well as underground contamination, such as a surface contaminated crib, it could have both postings.

\begin{tabular}{ccc} 
Radiation Area & $\begin{array}{c}\text { Surface Contamination } \\
\text { estimated (acres) }\end{array}$ & $\begin{array}{c}\text { Underground Rad Material } \\
\text { (acres) }\end{array}$ \\
\hline 100 Area & 120 & 450 \\
200 Area & 330 & 300 \\
600 Area & 3,500 & 200 \\
$\begin{array}{c}\text { (includes BC controlled } \\
\text { area and UN-216-E-31 } \\
\text { controlled area) } \\
300 \text { Area }\end{array}$ & 30 & 10 \\
\cline { 2 - 3 } & 3,980 & 960 \\
\hline
\end{tabular}

"Includes areas posted as "Surface Contamination Areas" or as "Radiological Controlled Areas" and areas that have both underground and surface contamination.

'Includes areas with only underground contamination. Does not include areas that have surface as well as underground radioactive material. 
This page intentionally left blank. 


\section{DISTRIBUTION}

\section{Number of copies}

OFFSITE

$1 \quad$ Battelle Northwest

4000 N.E. 4lst Street

Seattle, WA 98105

S. L. Stein

\section{ONSITE}

25 U.S. Department of Energy-

Richland Operations Office

M. J. Anthony

R4-04

G. M. Bell

A5 -55

W. W. Bixby

E. A. Bracken

A7 -50

G. J. Bracken

A5 -19

K. V. Clarke

R4-04

P. F. Dunigan, Jr.

A5- 90

R. D. Freeberg

A5 -19

R. E. Gerton

A5 -19

J. P. Hamric

A5-21

R. A. Holten

A7 -50

J. R. Hunter

A5 -55

R. D. Izatt

A6-53

R. D. Larson

A5 -19

L. E. Little

A7 -80

K. L. Morgan

A5-22

T. P. Pietrok

A7 -75

E. E. Pride

M. W. Tiernan

A5 - 19

A4-52

S. L. Trine

A5 -55

J. D. Wagoner

A5 -19

L. C. Williams

A7 -50

S. H. Wisness

Environmental Restoration: Division Staff (2)

A5 -18

A5 - 19

A6-95

1 Hanford Environmental Healin Foundation

L. J. Maas

B2 - 75

2 Kaiser Engineers Hanford

W. H. Bodily

E3-33

R. T. French 


\section{DISTRIBUTION (cont)}

\section{Number of copies}

\section{ONSITE}

9 Pacific Northwest Laboratory

W. J. Bjorklund

G. L. Harvey

Kl -55

G. R. Hoenes

R. E. Jaquish

P7-78

J. F. Keller

K $1-30$

T. A. Nel son

K1-51

D. J. Pond

$\mathrm{K} 1-36$

R. G. Schreckhise

$K 6-66$

D. B. Shipler

W. L. Templeton

1 Stone and Webster Engineering

R. X. Gonzalez

A4-35

81 Westinghouse Hanford Company

M. R. Adams

T. M. Anderson

H4 -55

B. A. Aust in

B3-01

H. Babad

B2 -14

M. V. Berriochoa

B3 -68

D. G. Black

B3 -30

R. J. Bliss

L. C. Brown

$B 2-20$

M. C. Brown

B3 -04

H4 -51

J. G. Burk

B2 -20

G. D. Carpenter

B3 -25

J. G. Cassady

N. E. Darling

C. DeFigh-Price

B2 - 16

B3 -07

B2 -19

J. L. Deichman

B3 -68

L. P. Diediker

B3 -68

W. T. Dixon

M. C. Druby

G. T. Dukelow

$\mathrm{T} 1-30$

B2 -35

B3 -30

R2 -97

C. Edwards

B3 - 26

P. R. Edwards

B5 -25 


\section{DISTRIBUTION (cont)}

\section{Number of copies}

\section{ONSITE}

\section{West inghouse Hanford Company}

J. H. Ellis

R. H. Engelman

R2 - 67

D. J. Farquhar

H4 -57

M. R. Fox

B1-24

R. D. Fox

J. S. Garfield

B2 - 35

C. J. Geier

E. M. Greager

F. T. Green

W. H. Hamilton, Jr.

H4 -52

R3-63

H4 -57

L6-60

J. M. Hanson

H4 - 18

H. D. Harmon

N3 -10

R. C. P Hill

R2 - 40

K. L. Hoewing

R2-52

J. 0. Honeyman

$B 4-53$

B3-06

D. G. Horton

B1-41

M. C. Hughes

H4 -56

J. E. Irvine

L4 - 88

G. W. Jackson

G6-14

V. G. Johnson

R4-01

K. R. Jordan

H4 -56

W. R. Klink

B3-51

J. R. Knight

B3 -30

M. K. Korenko

$B 4-52$

M. J. LaBarge

B3- 08

$R$. L. Ledingham

B2 - 19

R. E. Lerch

H4 -55

D. W. Lindsey

B2 -35

K. A. McGinnis

R2-82

H. E. McGuire

G2 -02

W. J. McKenna

D. E. McKenney

B2 -35

B3 -27

D. L. Merrick

R $1-48$

W. C. Miller

G. J. Miskho

R. D. Morrison

R2 - 20

G6-06

Rl -48

W. I. Munn

D. J. Newl and

B2 - 35

HO -32

R2 - 28

S. M. O'Toole

B2 -20

R. A. Paasch

B2 -20 


\section{DISTRIBUTION (cont)}

\section{Number of copies}

ONSITE

\section{Westinghouse Hanford Company}

P. M. Phelps

B3 -30

B. L. Preecs

B2 -20

S. M. Price

H4 -57

J. H. Roecker

B3-04

F. A. Ruck III

H4 -57

W. G. Ruff

R2-53

J. A. Seamans

$\mathrm{N} 1-36$

D. H. Shuford

S5-66

R. G. Slocum

R2 - 34

D. J. Sommer

$\mathrm{B} 2-20$

D. R. Speer

R2 -77

D. F. Spellman

B3 -26

C. T. Sullivivan

B3 -35

D. S. Takasumi

T. L. Traub

RJ -27

J. E. Van Beek

R1 -65

G. E. VanSickle

R3-27

T. C. Varljen

R1- 15

E. P. Vodney

B3 -65

J. L. Waite

B3 -50

D. J. Washenfelder

B2- 35

D. D. Wodrich

RI -43

R. D. Wojtasek

R2 -23

EDMC (2)

Central Files

Publication Services

L4-92

$\mathrm{H} 4-22$

L8-15

L8-07 

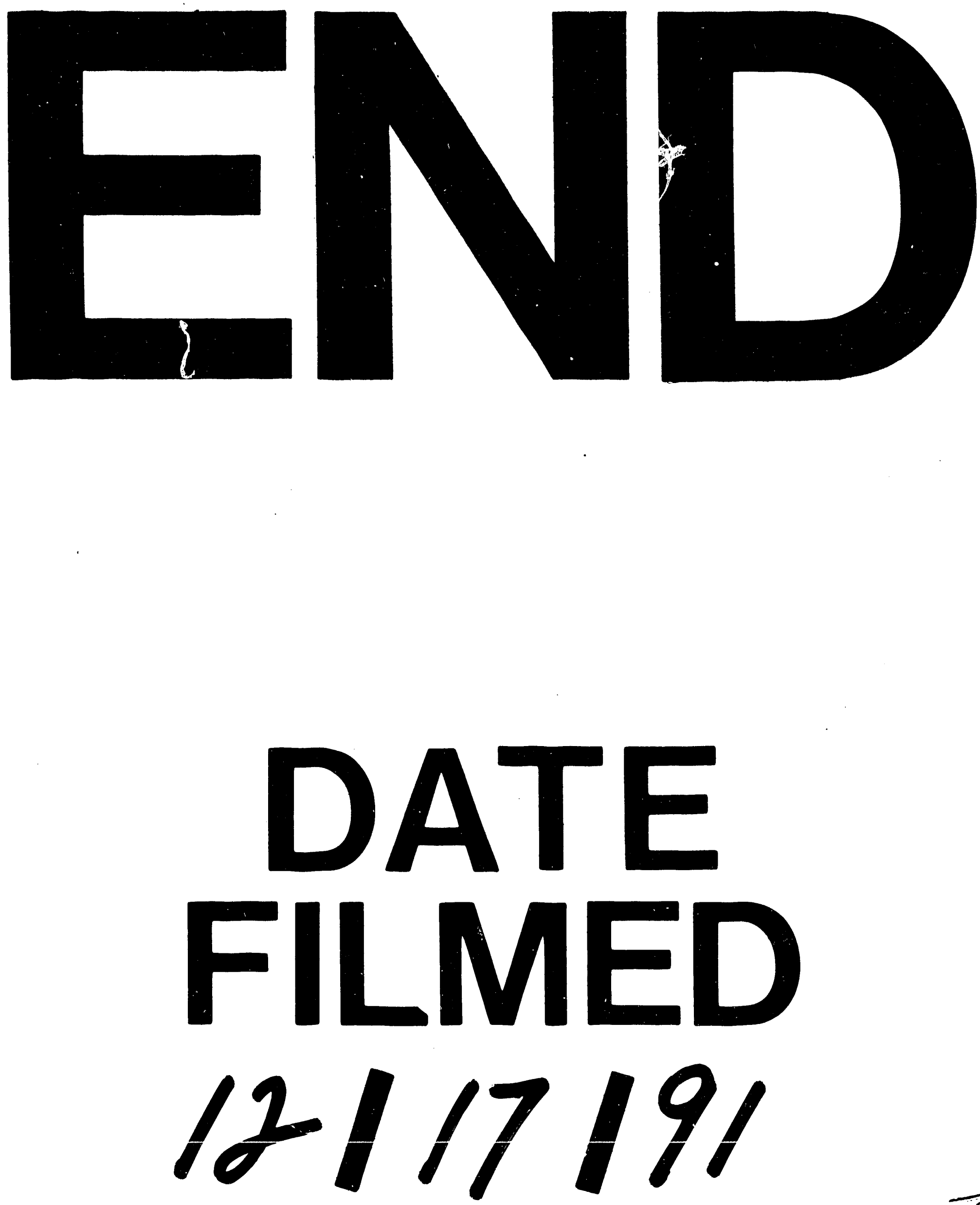

1 
